\title{
Cenozoic Megafossils
}

of Northern Alaska

By F. STEARNS MACNEIL

SHORTER CONTRIBUTIONS TO GENERAL GEOLOGY

GEOLOGICAL SURVEY PROFESIONAL PAPER 294-C

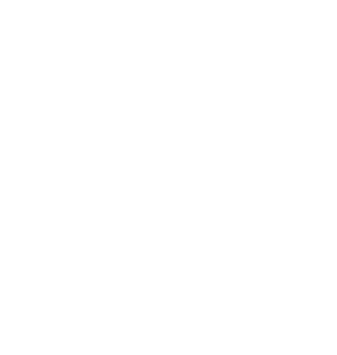

UNITED STATES GOVERNMENT PRINTING OFFICE, WASHINGTON : 1957 


\section{UNITED STATES DEPARTMENT OF THE INTERIOR \\ FRED A. SEATON, Secretary}

\section{GEOLOGIGAL SURVEY}

Thomas B. Nolan, Director 


\section{CONTENTS}

\begin{abstract}

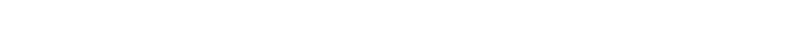

Faunules and faunal zones.

Megafossils of the Nuwok formation of Dall (1919)

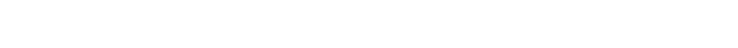

Pelecypoda

Scaphopoda

Brachiopoda

Cirripedia............

Unidentified worm tubes
\end{abstract}

Page

99

99

100

100

101

103

107

107

108

108

Megafossils of the Gubik formation
Gastropoda
Pelecypoda.
Cirripedia.
Unidentified worm tubes
Descriptions of new species
$\quad$ Nuculana morrisi MacNeil, n. sp
Chlamys nuwokensis MacNeil, n. sp
List of localities.
Literature cited
Index

\section{ILLUSTRATIONS}

\section{[Plates follow index]}

Plate 11. Fossils of the Nuwok formation of Dall, Chlamys nuwokensis zone.

12. Fossils of the Nuwok formation of Dall, Arctica carteriana zone.

13. Fossils of the Gubik formation, Neptunea leffingwelli faunule.

14. Fossils of the Gubik formation, Neptunea leffingwelli faunule and Neptunea ventricosa communis faunule.

15. Fossils of the Gubik formation, Neptunea ventricosa communis faunule and Neptunea ventricosa soluta faunule.

16. Fossils of the Gubik formation, Neptunea ventricosa? soluta faunule and Neptunea ventricosa clarki faunule.

17. Fossils of the Gubik formation, Point Barrow terrace gravels and western American Neptunea of the $N$. lyrata-N. ventricosa group.

Figure 48. Map showing location of areas from which Tertiary and Quaternary fossils have been obtained. 



\title{
SHORTER CONTRIBUTIONS TO GENERAL GEOLOGY
}

\section{GENOZOIC MEGAFOSSILS OF NORTHERN ALASKA}

\author{
13y F. Stearns MacNerL
}

\section{ABSTRACT}

Marine invertebrates have been obtained from late Tertiary beds (late Miocene or Pliocene or both) and Quaternary beds on the Arctic coastal plain. The supposed Miocene fauna is closely related to north Atlantic and European middle Tertiary faunas but considerably less closely related to Pacific middle Tertiary faunas. This may indicate that during the Miocene, Atlantic elements entered the polar sea but that there was no communication between the polar sea and the Pacific at that time.

Conversely the Quaternary faunas show relationships with both the Atlantic and Pacific, and some nearly identical mollusks found living in boreal waters on both sides of North America but not living in the Arctic are found in them. This suggests that there was a migration of indigenous Pacific types to the Atlantic, and of indigenous Atlantic types to the Pacific along the Arctic coast during the Pleistocene and possibly late Pliocene.

Several characteristic faunules are found in the Quaternary (Gubik formation), each distinguished by a different species of Neptunea. The explanation favored for this situation is that the Gubik formation contains several nonsynchronous and isolated zones of near shore facies, deposited during a period of oscillating strand, and that different faunas migrated along these different strands at different times. A similar situation has been demonstrated in the Nome area, where there is a series of strand lines on bedrock and strand line deposits in beds above the bedrock.

Two new pelecypods are described: Nuculana morrisi and Chlamys nuwokensis.

\section{INTRODUCTION}

The only invertebrate fossils found to date in postCretaceous rocks on the Arctic coastal plain are of late Tertiary and Quaternary age. The Tertiary fossils were obtained by Martin in 1912, Leffingwell in 1914, and Morris in 1953, from a section on Carter Creek, a stream flowing into Camden Bay (fig. 48). Fossils in

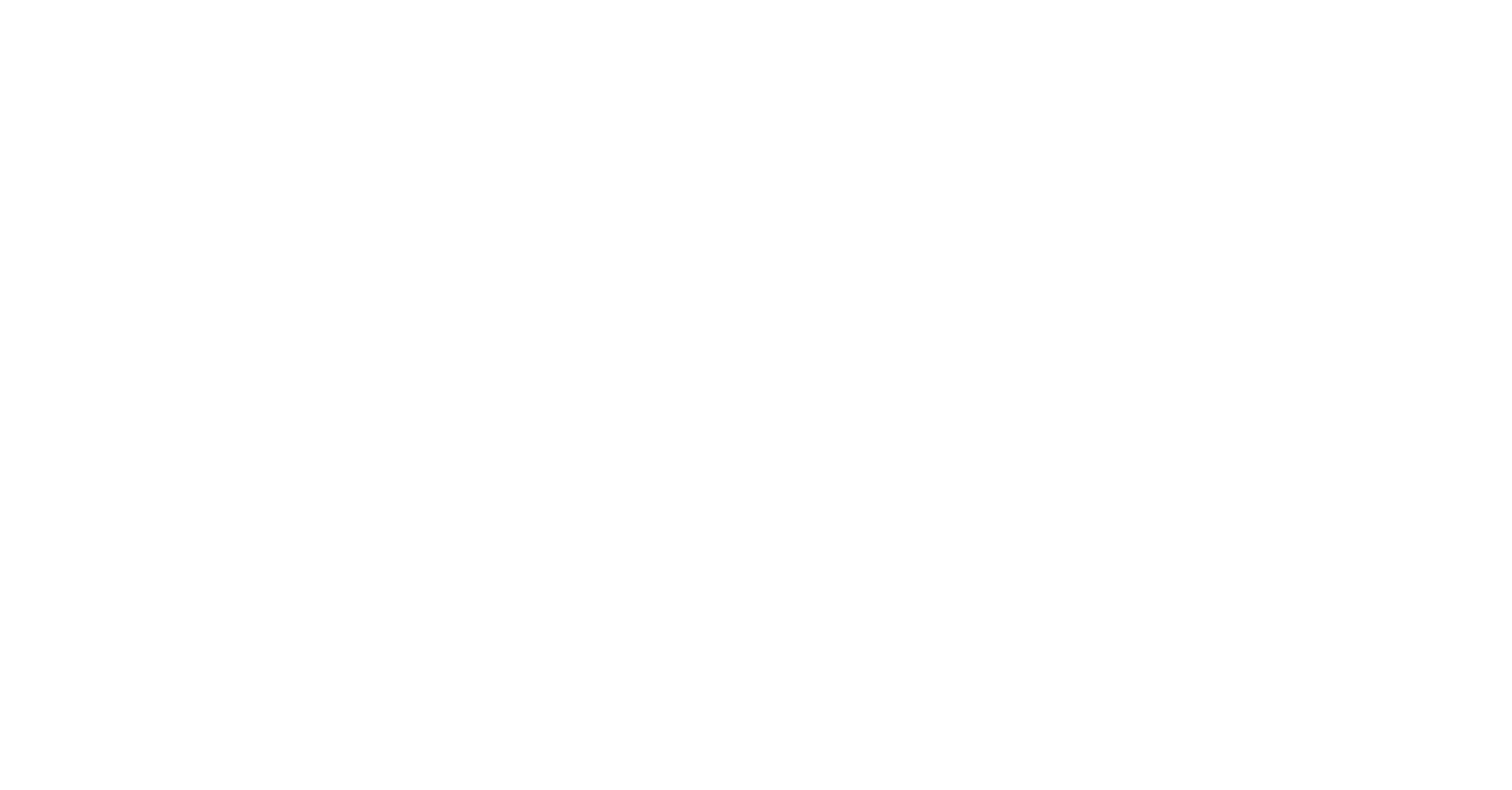

Frgune 48.-Map showing location of areas from which Tertiary and Quaternary fossils have been obtained: (1) Carter Creek, a stream flowing into Camden Bay; (2) Colville River at and below the mouth of Kikiakrorak River; (3) Skull Cliff, Peard Bay; (4) Meade River at latitude $70^{\circ} 30^{\prime} ;(5)$ Kukpowruk River at latitude $69^{\circ} 21^{\prime} ;(6)$ Bluff along Peard Bay about 30 miles southwest of Point Barrow; (7) Bluff about 15 miles southwest of Point Barrow; (8) near Point Barrow. 
the earlier collections were identified by Dall (Leffingwell 1919, p. 130). Later Dall (1920) reviewed the fauna and described several new species from it. On original field labels accompanying both Martin's and Leffingwell's collections the beds were designated the "Nuwok formation", a name that was never formally adopted by the U. S. Geological Survey. However, the name Nuwok formation was used by Dall twice in his contributions to the Report of the Canadian Arctic Expedition of 1913-18 (Dall, 1919a and O'Neill, 1924).

Recently the name Sagavanirktok formation (Gryc, Patton, and Payne, 1951; also Payne and others, 1951) was applied to a sequence of beds to the west of the Camden Bay area, and this sequence was assigned on the basis of fossil plants to the lower Tertiary. This is the only name applied until this time to supposed Tertiary beds on the Arctic coast of Alaska other than the name Colville series, no part of which is now thought to be definitely Tertiary. The Sagavanirktok formation as originally defined did not include Tertiary rocks along Carter Creek although it is possible that the lower part of the Carter Creek section may be equivalent to the Sagavanirktok formation.

The mollusks from the highest beds on Carter Creek are thought by the author to be upper Tertiary; upper Miocene or lower Pliocene or both. If the Sagavanirktok formation is of early Tertiary age, as indicated by the plant fossils, it seems desirable to recognize at least the uppermost beds on Carter Creek as a separate formation even though the boundary between them and the Sagavanirktok formation is not yet known. It is very improbably that a single conformable sequence could embrace all of the Tertiary, here or elsewhere. The name Nuwok formation has been used in Canadian literature and the name muwokensis is perpetuated in the name of a species described by Dall from Carter Creek. The name Nuwok formation might be established for the late Tertiary beds exposed along Carter Creek, leaving the delimitation of the formation to future work.

A blanket deposit of gravel, sand, silt, and clay called the Gubik formation rests comfortably on the Tertiary in some areas and on Cretaceous elsewhere. Fossiliferous beds along the lower Colville River, which were included in the upper Colville Series by Schrader (1904) and assigned to the Pliocene, have (Payne and others, 1951) been reassigned to the Gubik formation and asigned to the Pleistocene. The lower part of the Colville Series that Schrader regarded as Oligocene is now regarded as Cretaceous, and the Colville group, as used by the U. S. Geological Survey, now includes both marine and nonmarine formations.
Thus far the Gubic formation has yielded fossils from several widely separated areas; in some areas only one fossil locality is known. A rather distinctive faunule appears to occur in each area. Each faunule is characterized by several species not found in the others although some of the ubiquitous species of the Arctic such as Saxicava arctica, Macoma calcarea, and Serripes groenlandicus are found in more than one faunule and may be common to all. The genus that appears to distinguish the faunules best in Neptrinea, each faunule containing a different species or variety. A still different form occurs along the present Arctic coast (p. 112).

Details of the Gubik formation are not well known. The rather striking difference in the fauna from different localities, in spite of the probability that the monotonous Arctic shelf did not offer any great contrasts in environment, may suggest that the Gubik is not one unit but consists of several thin units of slightly different age. It seems possible that on the Arctic slope, as in the Nome area, there may be a series of strand lines, both on the underlying rocks and in the overlying deposits, and that different faunas found their way along different strands at different times.

\section{FAUNULES AND FAUNAL ZONES}

Four faunules from the Gubik formation and two fossiliferous zones in the Nuwok formation of Dall (1919) are delimited here. Zones of the Nuwok are listed in ascending order. The faunules in the Gubik may or may not be in ascending order.

Gubik formation:

Peard Bay in part and Kukpowruk River. 6. Neptunea ventricosa soluta faunule.

Meade River.

5. Neptunea ventricosa communis faunule.

Peard Bay, in part.

4. Neptunea ventricosa clarki faunule.

Colville River.

3. Neptunea leffingwelli faunule.

Nuwok formation:

2. Aretica carteriana zone.

1. Chlamys nuwokensis zone.

\section{MEGAFOSSILS OF THE NUWOK FORMATION OF DALL (1919)}

A section estimated to be about 7,000 feet thick (Morris, R. H., 1954, written communication) and containing silty shale, sandstone, and mudstone occurs along, and in country adjacent to, Carter Creek near Camden Bay. Fossils have been found so far only in the upper 266 feet of the section (Morris, R. H., 1954, written communication). Nuwok formation of Dall is 
used here only for the fossiliferous beds. No opinion is held on the age or possible formational assignment of the remainder of the estimated 7,000 feet of section. No fossils of any kind were found in the section below the upper 266 feet although many samples were examined for Foraminifera. Fossils were first collected in 1912 by Martin, and two years later Leffingwell collected additional specimens. Preliminary identifications of the fossils were made by Dall (Leffingwell, 1919), and later Dall (1920) described some of them as new species. While Dall recognized the fauna as unusual for that latitude, further preparation of some of the original specimens has revealed facts about them more pertinent to possible faunal migrations during the Tertiary than Dall realized.

According to Martin's and Leffingwell's original labels, their fossils came from the upper 210 feet of the section. This is partly substantiated by collections made by Morris in 1953, which contain some rock similar to that in which Martin's and Leffingwell's fossils occur. Unfortunately, however, the Morris collections, while containing several other species, do not contain any of the species found in the Martin and Leffingwell collections. In addition, Morris found that the next underlying 56 feet of silty shale contained very fragile but nevertheless well preserved fossils. With the possible exception of a couple of species, which are unidentifiable on the basis of the material at hand, all are different species from those found in the beds above. It is not known at present whether the apparent dissimilarity between faunas from the highest and lowest fossiliferous beds is real or whether it merely reflects the incompleteness of our knowledge of the total contained fauna.

It is believed at present that at least the lower fossiliferous beds on Carter Creek are of late Miocene age. Dall regarded the fauna of the upper 210 feet as Pliocene. The possibility remains, of course, that all of the fossiliferous beds may be Miocene or all may be Pliocene.

The fauna in them bears little resemblance to supposed Miocene faunas from the Gulf of Alaska region. This lack of similarity with the faunas of the Yakataga formation (Miocene and Pliocene?) of the southern coast of Alaska and the Unga formation (late Miocene) of the Alaska Peninsula region, in spite of the fact that generally warmer conditions seem to have prevailed, strongly suggests that Bering Strait was closed at that time.

Conversely, there are species from both the higher and lower parts of the Carter Creek section that are much more closely related to living or fossil Atlantic species of the same genus than to any known Pacific species. Some species have been tentatively identified as living Atlantic species, and one genus, Arctica, is known to have existed since the Cretaceous only in the north Atlantic province, including the Baltic and Mediterranean regions.

However, there are some possible relationships between Carter Creek species and some elements of postMiocene Pacific faunas. This may indicate that typically Atlantic types that had gained access to the polar sea during the Miocene entered the Pacific during the Pliocene when Bering Strait was opened. The reverse also seems to be true-that some types characteristic of the Tertiary of the north Pacific reached the north Atlantic region in Pliocene and early Pleistocene time but not before.

The distribution of the species in the Tertiary strata along Carter Creek is shown in the accompanying table (p. 102). This includes all specimens in the Morris collections and specimens in the Martin and Leffingwell collections that were found. One specimen reported previously from Tert. loc. 7069 appears to be lost. In Leffingwell (1919) it was listed as Admete cf. A. regina Dall.; in Dall (1920) as Antiplanes cf. A. purpurea Dall.

Illustrations of fossils from the Chlamys nuwokensis zone, the lower 56 feet of the fossiliferous beds on Carter Creek (pl. 11), are kept separate from those of the Arctica carteriana zone, the upper 210 feet (pl. 12).

\section{GASTROPODA}

Genus EMARGINULA Lamarck 1801

Emarginula (Subemarginula) sp. aff. E. (S.) yatesii Dall

Plate 11, figure 1

Subemarginula Blainville 1824 (=Hemitoma Swainson 1840) is differentiated from typical Emarginula by having a very shallow marginal indentation. The ribs of the Carter Creek species are less coarse than those of the Recent $E$. (Subemarginula) yatesii Dall, which lives on the west coast of North America from Alaska to Monterey. A species closely related to $E$. yatesiz, $E$. (Subemarginula) vadososinuata Yokoyama, occurs in the Pliocene and Pleistocene of Japan.

Typical Emarginula is nearly worldwide in distribution at the present time. Both warm and cool water species are known, but the majority of living species are in warm water. No Tertiary species of Emarginula are known from western North America, but $E$. gabbi Stewart occurs in the Cretaceous of California. In the Atlantic province, however, $E$. marylandica Martin is found in the middle Miocene (Choptank formation) of Maryland and two species, E. nystiana Bosquet and $E$. fasciculata von Koenen, are known from the Oligocene of Germany (see Albrecht and Valk, 1943, pl. 1, figs. 
Distribution of species in the Tertiary strata along Carter Creek, Camden Bay region

[X, occurs; ?, doubtful identifications; T, type locality]

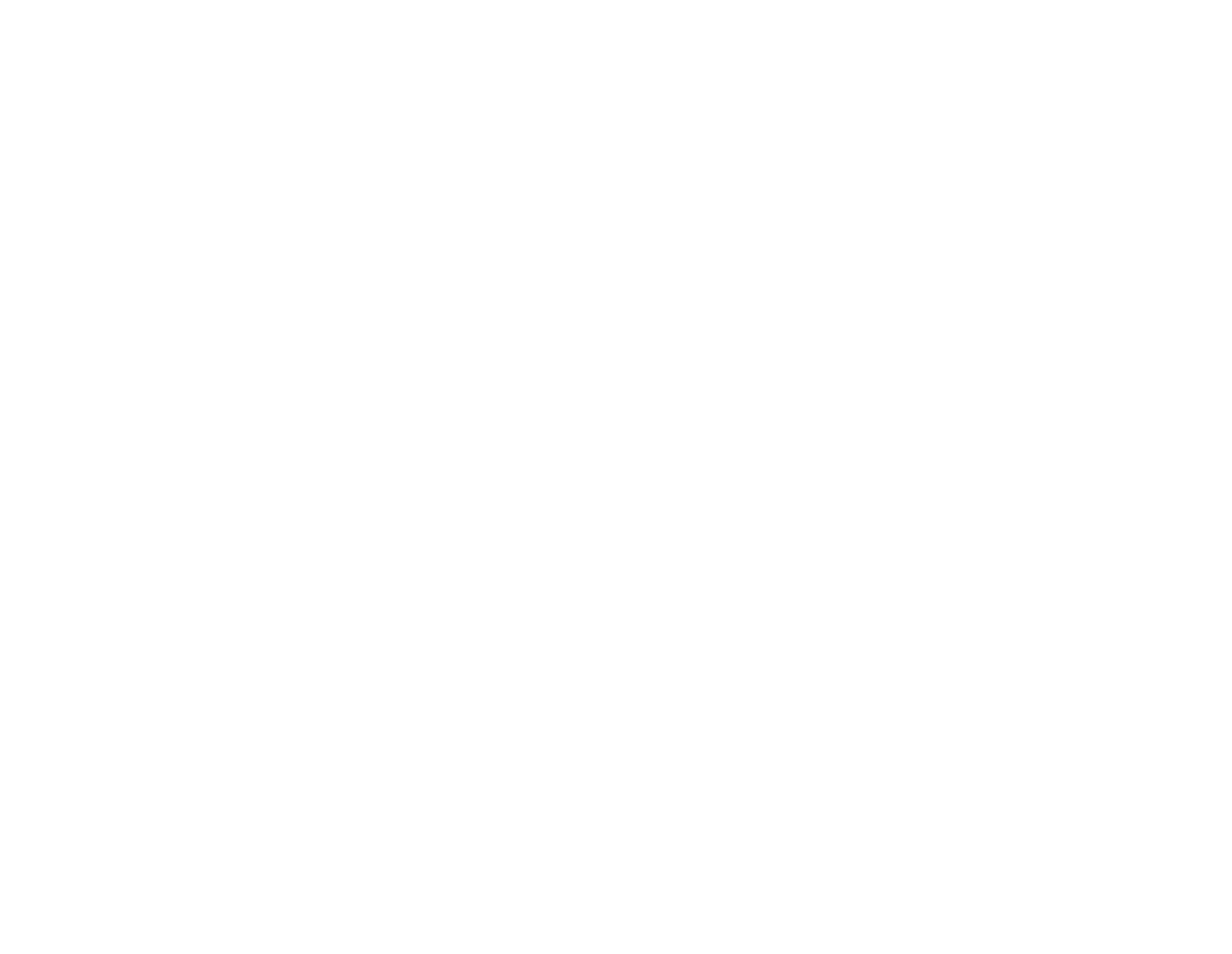

1 Collections, D numbers in Denver, others in Washington.

2 The Cyrtodaria in 7068 a may be C. kurriana (Dunker). According to Leffingwell (1919): $7230=7068,7231=7070$.

Note.-See following table for explanation of collection numbers.

\begin{tabular}{|c|c|c|}
\hline No. & Collectors & $\begin{array}{l}\text { Position below } \\
\text { top of section; } \\
\text { in feet }\end{array}$ \\
\hline $\begin{array}{l}7068 \mathrm{a} \\
7230 \\
7068 \mathrm{~b} \\
\text { D48 (T) } \\
7069 \text { (T) } \\
\text { D49 (T) } \\
\text { D52 (T) } \\
7070 \\
7231 \\
\text { D50 (T) } \\
\text { D52 (T) } \\
\text { D51 (T) }\end{array}$ & $\begin{array}{l}\text { Martin and Leffingwell } \\
\text { do } \\
\text { Morris } \\
\text { Martin and Leffingwell- } \\
\text { Morris } \\
\text { Martin and Leffingweil } \\
\text { Modo } \\
\text { do }\end{array}$ & $\begin{array}{c}0-30 \\
0 ?-30 \\
30 \\
0-50 \\
110 \\
110-210 \\
\text { talus }(? 110-210) \\
210 \\
210 \\
210-258 \\
\text { talus }(? 210-258) \\
258-266\end{array}$ \\
\hline
\end{tabular}

1-3). Presumably Subemarginula is derived from typical Emarginula, but exactly when the derivation occurred is not known. However, the German Oligocene forms are likely ancestors.
Emarginula crassa J. Sowerby occurs in the Coralline Crag (Pliocene) of England ${ }^{1}$ (see Harmer, 1923, pl. 62, figs. 1-3), the Pliocene of Holland, the Pleistocene of England, and it is living from England to northern Norway. It has crude primary ribs that are divided into

1 The sequence of the Crag deposits of England and their age according to opinions expressed in the symposium on the boundary between the Plfocene and Pleistocene at the 18th International Geologic Congress, Great Britain, 1948, is as follows :

Pleistocene (probably all Günz) Weybourne Crag)

Chillesford beds Icenian Crag

Norwich Crag

Norfolk stone bed

Butley Crag

Newbourne Crag Red Crag

Walton Crag

Suffolk bone bed

Pliocene (uppermost)

Coralline Crag 
better defined secondary ribs. The Carter Creek species, on the other hand, has low, smooth ribs with no secondary ribs. The siphonal emargination of the Carter Creek species is not preserved on the only specimen at hand, but the siphonal ridge is raised as in $E$. (S.) yatesii rather than low as in E. crassa.

It is possible that the Carter Creek species is intermediate between the Pacific Subemarginula and some typical Emarginula such as E. nystiana or E. orassa, but so far this is conjecture. At any rate, the Carter Creek species may be the ancestor of $E$. (S.) vadososinuata and $E$. (S.) yatesii for the subgenus seems not to have been in the Pacific prior to the Pliocene.

Localities: USGS D50 (T).

\section{Genus LUNATIA Gray 1847}

Lunatia sp. aff. L. groenlandica (Mö1ler)

Plate 12, figure 21

According to some authors L. pallida Broderip and Sowerby and $L$. borealis Gray are the same species. This species or group of closely related species is circumboreal at present, ranging southward to England, Cape Cod, Monterey, Calif., and Japan.

Localities: USGS Tert. loc. 7070.

Genus BUCCINUM Linne 1758

?Buccinum sp.

A fragment of a body whorl with inclined ribs may belong to Buccinum.

Localities: USGS Tert. loc. 7230.

Genus CoLUS Bolten (Roeding) 1798

?Colus sp.

Plate 12, figure 4

Internal molds of a Colus-like gastropod were taken from USGS Tert. loc. 7231, and a badly decorticated specimen of what may be the same species was taken from USGS Tert. loc. 7070.

Localities: USGS Tert. loc. 7231, ?7070.

Genus ANOMaLOSIPHO Dautzenberg and Fischer 1912

?Anomalosipho sp.

Plate 12, figures 2, 3

Poorly preserved specimens of a high-spired, rapidly expanding gastropod that appears to have a crooked spire resemble in general form a specimen from the Butleyan Crag that was figured by Harmer (1915, pl. 15, fig. 6) as Anomalosipho altus (S. V. Wood).

Localities: USGS Tert. loc. 7068a.

419591-57_-2
Genus SCAPHANDER Montfort 1810

Scaphander aff. S. lignarius (Linné)

Plate 11, figures 2, 10

Scaphander lignarius occurs in the Pliocene of England, Belgium, Holland, France, and Italy, the Pleistocene of England, and is living from Norway to the Mediterranean and Azores. Scaphander watsoni Dall, a closely related species occurs south of Cape Hatteras on the Atlantic Coast of the United States.

Scaphander lignarius has simple or wavy, usually well separated incised spiral lines and is easily distinguished by this character alone from the more bulbous S. punctostriatus Mighels and S. nobilis Dall, which have rows of punctations rather than continuous incised lines. The spirals are more numerous and more closely set in the Carter Creek form than in typical S. lignarius.

Scaphander has a wide distribution in the Tertiary. It is common in boreal waters but is not regarded as an Arctic shell. Its occurrence on the Arctic coastal plain is, therefore, outside its expected range. Large Scaphander are not commonly found as fossils and many more records will be necessary before specific lineages and migrations can be determined. However, there is some suggestion that the S. lignarius group had a Pacific origin. Several large to moderately large subpyriform Scaphander have been described from the Oligocene (and early Miocene?) of Washington and southern Alaska; S. washingtonensis Weaver and two subspecies of it (see Weaver, 1942, p. 545-546), and $S$. alaskensis Clark (see Clark, 1932, pl. 21, figs. 6-7). Both of these species have incised spiral lines rather than rows of punctuations, although in $S$. alaskensis they are so deep and broad that the interspaces are best described as raised spiral threads. Also in S. alaskensis the spiral threads are definitely paired. A specimen of S. alaskensis from the Poul Creek formation in the U. S. Geological Survey collections differs from the Carter Creek specimen only in sculpture; the shape, aperture, and apical characters are nearly identical.

Scaphander conradi Dall (see Weaver, 1942, pl. 100, fig. 8) from the Empire formation (Pliocene?) of Oregon resembles the Carter Creek form in shape but it is punctate.

Localities: USGS D50 (T).

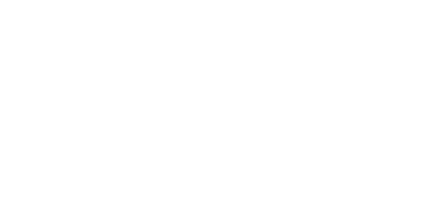

The internal mold of a large nuculid showing the hinge teeth but no external sculpture was identified by 
Dall as $N$. variabilis, a species of Acila, and it may be, but the diagnostic characters are missing.

Localities: USGS Tert. loc. 7068b.

\section{Genus NUCLANA Link 1807}

Nuculana morrisi MacNeil, n. sp. ${ }^{2}$

Plate 11, figure 3

A Nuculana, somewhat similar to the group of $N$. pernula (Müller), N. minuta (Fabricius), and N. lamellosa (Leche), is broader and less attenuated at the posterior end than of these species and the posterior sulcation between the dorsal margin and the weak posterior ridge is proportionately broader. This species may be related to $N$. leonina (Dall) (see Oldroyd, 1924, pl. 13, fig. 18), a deep water species found off the northwest coast of the United States, but $N$. leonina has higher beaks and a much more concave posterior dosal margin. Nuculana washingtonensis (Weaver) (see Weaver, 1942, pl. 8, fig. 26) from Weaver's (1912) Lincoln formation (Oligocene) of Washington is probably related, but it, too, is more attenuated posteriorly.

Localities: USGS D50 (T).

\section{?Nuculana sp.}

Plate 12, figure 26

An internal mold that may be a $Y$ oldia.

Localities: USGS Tert. locs. 7070, ?D48 (T).

Genus CHLAMYS Bolten (Roeding) 1798

Chlamys nuwokensis MacNeil, n. sp. ${ }^{\mathrm{s}}$

Plate 11, figures 4-6, 12

A new type of pectenid pelecypod, whose close relationships are very much in doubt, was obtained from the lower fossiliferous beds on Carter Creek.

It may be related to Chlamys sayanus (Dall) from the middle Miocene of Florida and $C$. virginianus (Conrad) from the middle and upper Miocene of Maryland and Virginia. The shell of the Carter Creek species is thin and translucent like that of the $C$. virginianus. It is possible that the Carter Creek species is a northern representative of the $C$. sayanus group, possibly derived from it.

On the other hand, the Carter Creek Chlomys may be related to and possibly ancestral to Fortipecten of the Pliocene and Pleistocene(?) of the Bering Sea region and Japan. The Japanese species of Fortipecten, $F$. takahashii (Yokoyama) has a very heavy shell but two other species (which may actually be one species), $F$.

\footnotetext{
2 See page 120 for description.

See pages 120-121 for description.
}

hallae (Dall) from a buried beach at Nome, Alaska, and F. piltunensis (Khomenko) (1931, p. 53, pl. 1, figs. 6-8; pl. 2, figs. 1-6) from the Supranutovo series (upper Pliocene or Pleistocene) of northern Sakhalin are thinner, although still moderately heavy. The Carter Creek species is more like the Atlantic Chlamys sayanus group in having concave dorsal margins and ribs of subequal size on the two valves. Fortipecten has convex dorsal margins and the ribs of the right valve are considerably broader than those of the left valve (see MacNeil, Mertie, and Pilsbry, 1943, pl. 12, figs. 1-2; pl. 13, fig. 1).

Though the ancestral relation of the Carter Creek Chlamys to Fortipecten is as yet unproved, it is equally true that Yabe and Hatai (1940) in their paper on Fortipecten could not link it with certainty to any Miocene pectenids from the Pacific region.

Localities: USGS D50 (T), D52 (T).

\section{Genus PAIIIOLUM Monterosato 1884}

Palliolum groenlandicum (Sowerby)

Plate 11, figure 17-18

This typically arctic form is reported by Soot-Ryen (1932) from the East Siberian Sea westward to Norway, in the Atlantic south to Sudan in Africa and the Gulf of Saint Lawrence, and Greenland west to Dolphin and Union Strait. It is not known in the Chukchi and Beaufort Seas, Bering Sea, or the Pacific. Its occurrence as a fossil in the Camden Bay area, near the center of the region where it does not now occur may indicate either that it was once circumarctic or that this was a migration from the east, just as its Recent occurrence in the East Siberian Sea may be a penetration from the west. If it was circumarctic during the late Miocene, it did not enter the Pacific; a further suggestion that Bering Strait was closed at that time.

Localities: USGS D50 (T).

\section{Genus MYTILUS Linné 1758 \\ ?Mytilus sp.}

Plate 12, figure 5

The beaks of the only specimen are decorticated and appear to be broad for Mytilus but narrow for Volsella. The low broad median inflation suggests a specimen figured by S. V. Wood (1851, pl. 8, fig. 10) as $M$. hesperianus Lamarck, a Recent species reported from the Coralline Crag. The Carter Creek form also appears to be closely related to $M$. californianus Conrad, a species known in the Pleistocene and Recent of the west coast of America.

Localities: USGS D 48 (T). 


\section{Genus ASTARTL Sowerby 1816}

Astarte sp. aff. A. laurentiana Lyell

Plate 11, figure 13

The specimen from Carter Creek is very similar in shape and in the size of the concentric ribs to the form described by Lyell from the Pleistocene deposits at Beauport in the Saint Lawrence River valley. It belongs to the group of $A$. crenata (Gray). The concentric undulations of the latter species become weak or die out on the posterior slope, a condition also true of the Carter Creek form. According to Dall's figure of A. polaris (1903, pl. 43, fig. 5) and Soot-Ryen's figure of $A$. crenata (1932, pl. 1, figs. 15-18), both species are shorter and higher than the Carter Creek form and $A$. polaris has coarser concentric undulations. Soot-Ryen (1932) reports $A$. crenata in the Pacific as far south as the Shumagin Islands, the distribution generally cited for $A$. polaris and presumably he regards them as identical.

Astarte concentrica Conrad from the upper Miocene of North Carolina is related, but its concentric undulations do not die out posteriorly. Other related species such as $A$. galeotti Nyst, $A$. gracilis Munster, $A$. sulcata (DaCosta) (for all see Heering, 1950), and $A$. incerta Wood (1853, pl. 17, fig. 4) are reported from the Coralline Crag of England. Other than the living $A$. polaris, which inhabits Bering Sea as far south as the Aleutians and Shumagin Islands, there are no Tertiary or Recent Astarte of this type in the Pacific.

Localities: USGS D50 (T).

\section{Astarte sp.}

Plate 11, figures 7, 8; ?Plate 12, figures 12, 15, 17-20

Two fragments believed to be of the same species occur in locality USGS D50 (T), and poorly preserved fragments of the same or a similar species are found in some of the higher beds. They may be related to the A. fabula-A. vernicosa Dall group but no closer identification is attempted. This group is now circumarctic and extends into both the north Atlantic and north Pacific. However, it has not been reported from the middle Tertiary of the north Pacific region. Some specimens, particularly those in localities USGS 7230 and 7070 , may be conspecific with the type of A. martini.

Localities: USGS Tert. locs. D50 (T), 7070, ?7230, ?7231.

\section{Astarte martini Dall}

Plate 12, figure 7

This species is represented by such poorly preserved specimens that its relationships and validity are in doubt. It probably belongs to the group of $A$. crenata (Gray).

Localities: USGS Tert. locs. 7231, ?7068a.

Genus CARDITA Bruguière 1792

Cardita (Cyclocardia) nuwokensis (Dall)

Plate 12, figure 22

This species is represented by the type and one other specimen, both too poorly preserved for proper appraisal. The 20 nodulose ribs separated by narrow but well-defined interspaces suggest some variants of $C$. crebricostata (Krause), a species which Soot-Ryen $(1932$, p. 19) combines with $C$. borealis (Conrad). Some related forms occur in the Coralline Crag of England (Wood, 1853, pl. 15). Without better material it is useless to attach any significance to this species.

Localities: USGS Tert. locs. 7068a, 7230.

\section{Genus Arctica Schumacher 1817}

Arctica carteriana (Dall)

Plate 12, figures $6,8,13-14,23,30$

This species is represented by fragments and poor specimens in three collections. A specimen from locality USGS 7231 (pl. 12, figs. 6, 8) was identified by Dall (1920, p. 27) as Astarte arctica, but the cleaning of its hinge area revealed that it belongs to the genus Arctica. A specimen from USGS locality 7069 was described by Dall $(1920$, p. 31$)$ as Astarte carteriana, although there seemed to be some doubt in Dall's mind that it was an Astarte inasmuch as he took pains to point out that the external ligament indicates it is not a Crassatellites.

Arctica is doubtfully recorded from the Knoxville formation (Upper Jurassic) of California and Arctica ovata (Meek and Hayden) is a common fossil in the Bearpaw shale (Upper Cretaceous) of Montana and Alberta. The genus has been recorded in rocks younger than Cretaceous, only from the north Atlantic and European region (see Nicol, 1951), and the occurrence of the genus in Arctic Alaska is of great significance in determining possible faunal migrations during the Tertiary. Arctica is found "subfossil" in Greenland but it does not live along Greenland now. It is also found "subfossil" in Novaya Zemlya. The presence of Arctica in the Carter Creek fauna supports the evidence of some other associated species that the Atlantic was its source.

Hagg (1927, pl. 6, fig. 23) figured an Arctica from the Tertiary of Spitsbergen which resembles $A$. carteriana. Localities: USGS Tert. locs. 7068a, 7069, 7231. 


\section{Genus TARAS Risso 1826}

?Taras sp.

Plate 11, figure 24

A thin globose ovate shell having the shape, convexity, and other general characters of a $S$ phaerella or Taras was found. The hinge area is missing. No Sphaerella is living at present north of Cape Cod, Mass.

Taras torrelli Jeffreys is recorded from southern Greenland in deep water. A thin globose Taras, T. orbellus Gould is reported living in the Pacific as far north as the Pribilof Islands, and it was found in the Inner Submarine Beach at Nome (MacNeil, Mertie, and Pilsbry, 1943, pl. 14, figs. 9, 10). Without better knowledge of this shell it seems useless to speculate on its significance.

Localities: USGS D50 (T).

\section{Genus SERRIPES Gould 1841 \\ ?Serripes sp.}

An internal mold with some shell adhering may be a Serripes but it could just as well be Arctica carteriana .

Localities: USGS Tert. loc. 7231.

\section{Genus THYASIRA Lamarck 1818}

Thyasira sp. aff. T. arctica Soot-Ryen and T. sarsii (Philippi)

\section{Plate 12, figures 9-10}

The Carter Creek form is higher than it is long and the greatest height is just anterior of center. It is similar in this respect to the Recent T. sarsii (Philippi) from the coast of Norway, T. fleovosa (Gould), a species found on both sides of the north Atlantic, T. croulinensis (Jeffreys), a Greenland species also found in European waters, and $T$. arctica Soot-Ryen from the East Siberian Sea. Thyasira gouldii (Philippi), which is sometimes regarded as a subspecies of $T$. flexusa, occurs in both the Atlantic and Pacific oceans, the Arctic Ocean, and possibly in the Indo-Pacific region. All these species appear to belong to a different group than that of T. disjuncta (Gabb) and T. bisecta Conrad, Miocene and Recent species from the west coast of America, which have elongate shells with comparatively narrow anterior ends.

All the rotund forms are limited to the north Atlantic and Arctic except for T. gouldii, which is recorded from the Pacific no earlier than Pliocene (Grant and Gale, 1931, p. 282; Yabe and Nomura, 1925, p. 12).

The relationship of the Carter Creek species to $T$. arctica and $T$. sarsii is assumed partly because of size, for these shells are of comparable size whereas all the other rotund forms are small shells (less than 10 millimeters in diameter).
On the basis of present knowledge, the Carter Creek species belongs to an Atlantic and Arctic group that contains both large and small shells. None of the largeshelled species are known to have entered the Pacific, but one of the small-shelled species did enter the Pacific in Pliocene time, presumably from the Arctic.

Localities: USGS D49 (T), D52 (T).

\section{Genus THRACIA Blainville 1824}

Thracia sp. aff. T. truncata Brown (=T. myopsis Möller) Plate 11, figures $9,11,15$

A poorly preserved specimen compares in shape with a specimen figured by Sars (1878, pl. 6, fig. 10), as $T$. truncata var. devexa. Sars records $T$. truncata from Norway, Iceland, Greenland, and boreal North America. Localities: USGS D50 (T).

\section{Genus PERIPLOMA Schumacher 1817}

Periploma sp. aff. P. fragilis Totten

Plate 11, figures 14, 20

The specimen is poorly preserved and the hinge is not visible. Periploma fragitis is living from Labrador to New Jersey. Periploma abyssomum Verrill, a species related to $P$. fragilis, was reported by Soot-Ryen (1932, p. 10) as having been dredged from the Chukchi Sea east of Wrangell Island. No living species of Periploma is known north of Labrador and Soot-Ryen raised the question of whether the specimen from the Chukchi Sea was a recently dead specimen or a Tertiary or Quaternary fossil. He favored the latter interpretation. If his interpretation is correct, both the Chukchi Sea and Carter Creek records are evidence of the invasion of the polar sea by boreal species in Tertiary time.

Localities: USGS D50 (T), D52 (T).

Genus MaCOMA Leach 1819

Macoma sp. cf. M. calcarea (Gmelin)

Plate 12, figure 11

Dall listed a Tellina from locality USGS 7231 (200B) (Leffingwell, 1919, p. 130) and the specimen, figured here on plate 12, figure 11, is so labelled. This appears, however, to be a Macoma with its ventral part missing, giving it the appearance of an elongate Tellina. Macoma calcarea is a circumarctic species ranging southward to Denmark, Long Island, Oregon, and Japan. Macoma calcarea is regarded as having originated in the Pacific, even though some supposed Tertiary records are questionable both as regards specific identity and age assignment.

Localities: USGS Tert. loc. 7231. 


\section{Genus CYRTODARIA Daudin 1799}

Cyrtodaria camdenensis Dall

?Plate 11, figures 21,22 ; plate 12 , figures $24,25,28$

This species, described from locality USGS 7070, is shorter and higher than $C$. kurriana (Dunker) (pl. 14, figs. 7, 9), the Recent circumarctic species. Cyrtodaria has not been recorded from the Pacific region except for the Recent species, which ranges into Bering Sea as far south as Norton Sound. It is fossil in the Tertiary of Europe. Both Ravn (1929) and Hagg (1927) figured forms of doubtful generic assignment from the Tertiary of Spitzbergen which resemble $C$. camdenensis.

Localities: USGS Tert. locs. ?D50 (T), 7068a, 7070.

Genus MARTESIA Blainville 1824

?Martesia sp.

Plate 12, figure 1

A piece of carbonized wood in indurated rock contains several borings completely filled with secondary crystalline calcite. Although no shell was found on breaking one of them, they resemble the borings of a wood piddock in shape (see Morris, 1947, pl. 24, fig. 5). The shape of the borings suggests a wood-boring pholad rather than a teredid, but without the shell it would be difficult to determine the genus because there are several wood borers in both families.

Two species of wood piddock are found along the Atlantic coast at present, $M$. striata in warm water, and $M$. cuneiformis as far north as New England. However, they may live in floating wood and could be carried long distances. There seems to be no record of wood piddocks in the Arctic at present. One wood boring pholad, Xylophaga dorsalis, at least ranges into north boreal waters. According to Abbott (1954, p. 463 ), the latter lives in waterlogged wood on the bottom at depths of 100 to 300 fathoms.

Probably the wide range in size of these borings indicates that they are not larval cells of insects.

Localities: USGS D49 (T).

\section{SCAPHOPODA}

\section{Genus CADULUS Philippi 1844}

?Cadulus arcticus Dall

Plate 12, figure 27

All available specimens of this species except for the figured holotype were examined by Dr. William K. Emerson, Museum of Paleontology, University of California, who remarks as follows:

The material represents fragments of a Cadulus sp. indet., and poorly preserved, fragmental specimens of Dall's arcticus, which may be questionably referred to siphonodentalium, subgenus Pulsellum. It is larger than any of the known Atlantic. members of the genus. It appears to be close to siphonodentalium (P.) ozawai Yokoyama 1926, a Japanese species which is reported to range from the Sawane Pliocene to Recent. Whether or not the two are closely related, I do not know; your guess is as good as mine. Possibly the holotype would offer a better check for comparative relationships.

Unfortunately, little is known regarding the Alaskan Arctic scaphopods; the MacGinities found no specimens of this group during their survey of the Point Barrow waters, and I know of no records of scaphopods from the Eastern Arctic Ocean. A number of species, however, are recorded from the Western Arctic.

Localities: USGS Tert. loc. 7070.

BRACHIOPODA

\section{Genus TEREBRATULINA d'Orbigny 1847}

Terebratulina sp. aff. T. retusa (Linné)

(=caput-serpentis Linné auctores)

Plate 11, figure 16

A Terebratulina that appears to belong to the $T$. retusa group occurs in Tertiary locality USGS D50 (T). The only specimen, other than the preserved figured specimen, that might show a loop was found not to have one preserved. It is not known, therefore, whether it has a ring in its loop (an annuliform loop), as does the north European T. retusa and the west American T. unguicula Carpenter, or a simple loop with disconnected crural processes, as does the north Atlantic American species, T. septentrionalis Couthouy (see Sars, 1878, pl. 1, figs. 4c, 5 and Oldroyd, 1924, pl. 38, fig. 5). Terebratulina unguicula has disconnected crural processes in its young stages. Terebratulina japonica (Sowerby) from Japan, a species reported in that region from the Miocene to Recent, also has an annuliform loop. The Carter Creek species has no median septum in either valve, agreeing in this respect with both $T$. retusa and $T$. japonica. This character distinguishes it from another Recent Japanese form, T. (Surugathyris) surugaenis Yabe and Hatai, which has a low median septum. Terebratulina surugaensis has radial ribs that are more granular than those of either T. japonica or T. retusa and it appears to be wider than either. In general aspect, however, it is quite similar.

Yokoyama (1920, p. 182, pl. 19, figs. 15-18) identified a species from the Pliocene of Japan as T. caput-serpentis which Taki and Oyama (1954, pl. 20) reidentified as T. peculiaris Hatai. However, Hatai (1940, p. 223) did not list Yokoyama's figure in his synonymy, and his figures of $T$. peculiaris do not particularly resemble the form figured by Yokoyama. 
Although Terebratulina with coarse radial ribs have been recorded from more Tertiary strata in the Pacific region (see Hatai, 1940) than in the Atlantic, this alone may not have significant bearing on any possible Tertiary migrations through Bering Strait. Related species may have existed on both sides throughout Tertiary time.

Localities: USGS D50 (T), D51 (T).

Genus TEREBRatULA Mueller 1776

"Terebratula"sp.

Plate 11, figures 19, 23

Two incomplete specimens and a third nearly complete but crushed specimen of a smooth, round, moderately large terebratuloid were obtained. No loops were prepared and it is doubtful if any can be from the material at hand. The exact relationships of this species are not known, therefore. It bears some resemblance to T. grandis (Blumenbach) from the English Crag, but if the known specimens are adults the Carter Creek species is smaller. The common living west coast terebratuloid, Laqueus californicus (Koch) has a small foramen, but the northern subspecies, $T$. vancouverensis Davidson, has a larger foramen.

Localities: USGS D50 (T), D51 ( $\mathrm{T})$.

CIRRIPEDIA

Genus BaLaNUS Da Costa 1778

Balanus crenatus (Bruguière)

Plate 12, figure 29

The identification is Dall's (1920, p. 27). The same species probably occurs in locality USGS 7231.

Localities: USGS Tert. locs. 7068a, 7231.

Balanus balanoides (Linné)

Plate 12, figure 31

This identification is Dall's $(1920$, p. 27$)$.

Localities: USGS Tert. loc. 7231.

\section{UNIDENTIFIED WORM TUBES}

Plate 11, figures 1, 4

A worm tube is attached to the holotype of Chlamys nuwokensis, and a smaller, irregularly coiled tube is attached to the figured specimen of Emarginula (Subemarginula) sp. aff. E. (S.) yatesii.

Localities: USGS D50 (T).

\section{MEGAFOSSILS OF THE GUBIK FORMATION}

The Gubik formation is present not only in Alaska but extends over wide areas in the Yukon and Northwest Territories of Canada. Dall (1919a, O'Neill, 1924, p. 30-32) listed fossils from 21 localities in the Yukon and Northwest Territories in the Report of the Canadian Arctic Expedition of 1913-18. The fossils were obtained at altitudes as high as 320 feet above sea level and the terrace deposits containing them extend to a maximum of about 600 feet above sea level. Fossils from Alaska in beds now included in the Gubik formation were listed by Dall from an area along the Colville River (Schrader, 1904, p. 83) and two localities in the Peard Bay region west of Point Barrow (Leffingwell, 1919 , p. 149, Dall, 1920, p. 26-27). Some of the species reported by Dall from the Colville River were new and Meek (1923) described some new species from Skull Cliff, a locality on Peard Bay. Dall (Schrader, 1904, p. 96) also listed some specimens collected along the Arctic Coast beach between the Colville River and Cape Lisburne as Recent species, but from their preservation some of them appear to be fossils. The beach shells as well as the fossils listed in the Reports on the Canadian Arctic Expedition are distributed biologically in the collection of Recent mollusks in the U. S. National Museum. Of the fossils reported by Dall from the Colville River locality only the types of his new species, $N e p$ tunea leffingwelli and Pyrulofusus schraderi were found. The whereabouts of the other specimens is unknown. Dall (Smith and Mertie, 1930, p. 240-241) also identified fossils from five localities along the Inaru and Topagoruk Rivers near Point Barrow. Fossils from four of these localities were marine and one nonmarine. These fossils, collected by Gilluly in 1923, were not located.

Schrader (1904) and Dall (1920) did not regard the Colville River locality as part of the Gubik formation but recorded it as the upper part of the Colville series and referred it to the Pliocene. The lower part of the Colville series they regarded as Oligocene, but it is now thought to be Cretaceous. Meek (1923) did not question the Pliocene age of the Upper Colville but stated that it did not appear to be present in the Peard Bay area. He believed that no satisfactory correlation could be made on the basis of information available at that time. As presently interpreted the Colville River fauna may be equivalent to or possibly older than the Skull Cliff fauna. Both are older than the Meade River fauna. Faunas from the Kukpowruk River and from the region of Point Barrow are considered younger than the Meade River fauna.

The author tentatively follows the opinion of geologists who have worked recently in the area that the Colville River fossil localities (D305-306 T) are part of the Gubik formation, but with the reservation that the formation might not all be of Pleistocene age. The Colville River fauna seems to be most closely related 
outside the Arctic coastal area to a fauna occurring on Saint Paul and Saint George Islands in the Pribilof Islands. This fauna has usually been regarded as late Tertiary. The author is inclined to regard it as late Pliocene or early Pleistocene, but he does not intend this statement to mean that it is, therefore, Pleistocene. The Colville River fauna, and possibly the Skull Cliff fauna may still prove to be of late Pliocene age. If all beds referred to the Gubik are one formation, it may be a formation of late Pliocene and early Pleistocene age deposited by a sea that advanced landward and retreated seaward several times, the outer limit of some retreats being beyond the present land border.

An oscillating strand has been demonstrated in the Nome area where strand lines on bedrock and in beds above bedrock on both the present land and below the sea have been explored in great detail because they contain gold. Similar isolated strands may be present in the Gubik formation on the Arctic coast. The possibility that different faunas may have lived and migrated along strand lines of different position and different age seems to the present author to be the most reasonable explanation for the differences observed in the fossil faunules.

The accompanying table (p. 110) shows the distribution of species in the Gubik formation by locality. Four other collections of marine fossils were identified by Dall from localities along the Inaru and Topagoruk Rivers in the Point Barrow region but the collections have not been located. For a list of these species see Smith and Mertie, 1930, page 241 Some names applied by Dall to these species do not appear in the present list, but allowing for similarities all but Cardium ciliatum Fabricius probably are included in the present list under other names. Cardium ciliatum does not appear in any Gubik collection studied by the author, but it was reported at Skull Cliff (Univ. Calif. loc. 3627) by Meek. Meek listed three other species from Skull Cliff which could not be confused with any of the species reported here; Nuculana pernula (Müller), Yoldia limatula Say, and Siliqua patula Dixon.

The Gubik species are discussed in systematic order but the individual faunules are kept separate in the illustrations.

\section{GASTROPODA}

Genus TACHYRHYNCHUS Mörch 1868

Tachyrhynchus erosus major Dall

Plate 13, figures 16-17

This fossil is common at both localities on the Colville River but was not found elsewhere in northern Alaska. MacNeil (MacNeil, Mertie, and Pilsbry, 1943) re- ported this form from both the Inner Submarine and Intermediate beaches at Nome (early Pleistocene?). Dall (1919a and 1924) reported T. erosus (Couthouy) from Herschel Island, Yukon Territory, in a collection made "from 100 feet above sea level downward". Slodkevich (1935) also reports $T$. erosus from supposed Pleistocene deposits on Bukhta Lavrentiya in the Chukotskiy Poluostrov, along Bering Strait. Tachyrhynchus erosus is believed to be a circumpolar species, for it is found on the Arctic coasts of Asia, Europe, and America and at least the southern part of Greenland. It ranges to Cape Cod in the western Atlantic, and in the Pacific to British Columbia and Japan. The subspecies major is a large form which Dall recognized in Alaska ranging from the mouth of the Colville River to the Aleutians. According to Loyning (1932), $T$. erosus was dredged from a depth of 88 meters in the Chukchi Sea.

Localities: Colville River, USGS D305 (T), D306 ( $\mathrm{T})$.

\section{Genus NATICA Scopoli 1777}

Natica (Cryptonatica) clausa Broderip and Sowerby

Plate 13, figures 12, 13 ; plate 15, figure 19

Natica clausa is one of the commonest of the Arctic species, ranging southward to the Mediterranean, North Carolina, southern California, and Japan. Natica clausa was not found in the Nome beaches but Dall reports it from the Pleistocene of Herschel Island, Yukon Territory, and Meek lists it from the Pleistocene at Peard Bay. Grant and Gale (1931) regard $N$. consors Dall from the Empire formation (Pleiocene?) of Oregon as this species and list it from numerous localities in the Pliocene and Pleistocene of the west coast. Harmer (1921) identifies $N$. clausa in the Waltonian, Newbournian, and Butleyan Crag, the Pliocene of Iceland, and the Pleistocene of Norway, Greenland, the Saint Lawrence valley in Canada, Massachusetts, Siberia, and Japan.

An element of doubt concerning the identity of all forms referred to this species is apparent when reading the discussions by Grant and Gale and Harmer. Grant and Gale claim it is a small species confused with $N$. russa Gould (?aleutica Dall), a larger species, on the west coast, whereas Harmer applies the name to a large north Atlantic species and refers a smaller species to $N$. affinis (Gmelin). Probably the best that can be said at present is that fossils and some Recent records of this species at least belong to the $N$. clausa-N . russa-N. affinis group.

Localities: Colville River, USGS D306 (T) ; Meade River, USGS Tert. loc. ?15929 (fragment); Kukpowruk River, USGS D2 (T). 
Distribution of species in the Gubik formation

[ $X$, occurs;?, doubtful identification; $T$, type locality]

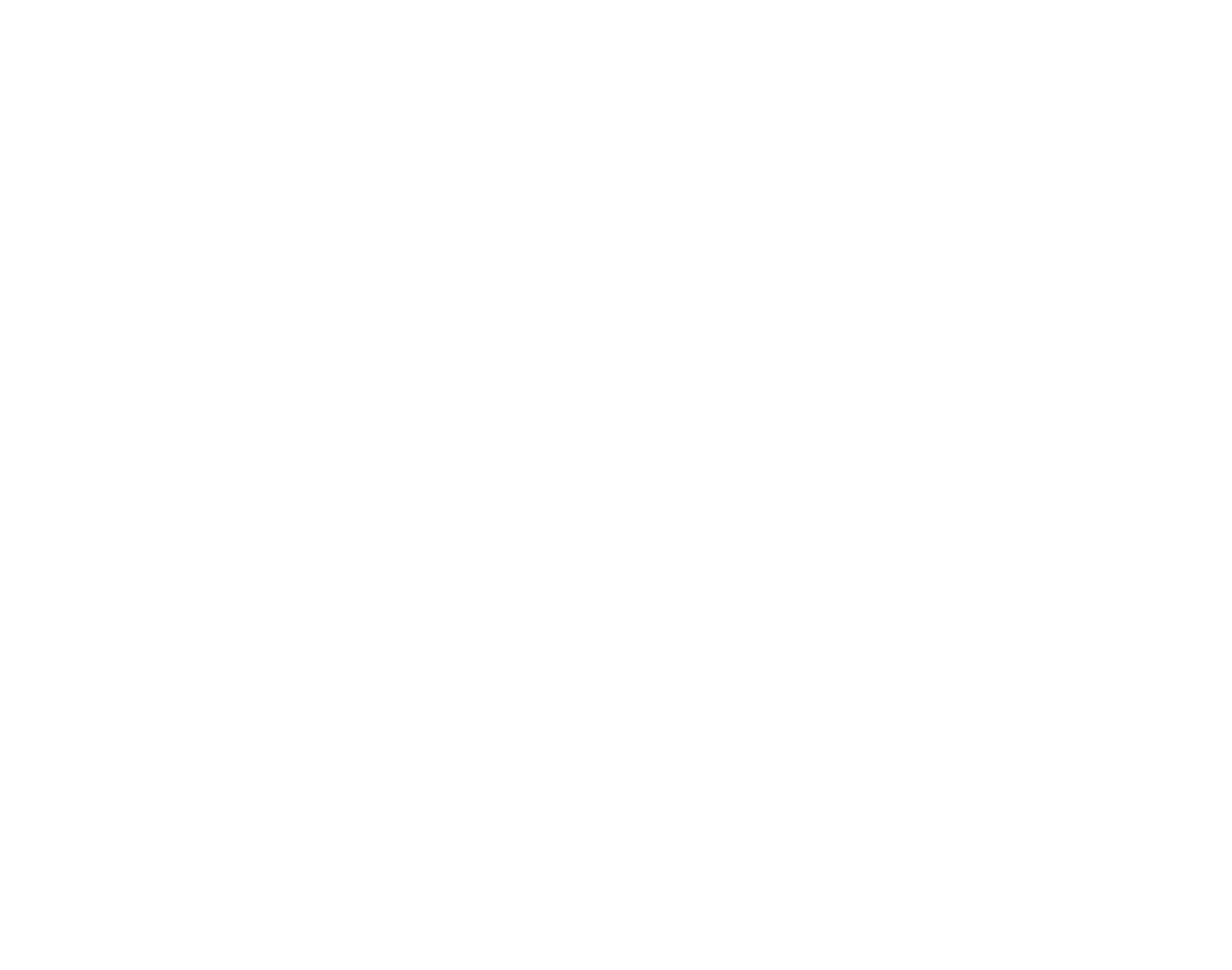

\section{Genus VOLUTOPSIUS Mörch 1857}

\section{Volutopsius sp. aff. V. stefanssoni Dall}

Plate 14, figure 14; plate 15, figures 21,22

The specimens on hand are too incomplete for positive identification. The body whorl of the larger and more complete specimen has low, broad, rounded axial ribs similar to those of $V$. bering $i$ (Middendorff) but there are no spiral ribs near the base as in that species. The axial ribs of $V$. stefanssoni are poorly developed and may be absent on the central and lower part of the whorl. The same range, Arctic Ocean to the Pribilof Islands, is given by Dall (1921, p. 89) for both species and they may prove to be the same. Volutopsius castaneus Mörch (see Oldroyd, 1927, pl. 4, fig. 2) is shown as having narrower and sharper axials, and the suture is high and appressed. The Arctic fossils have a low, V-shaped suture.

Localities: Meade River, USGS Tert. loc. 15929; Kukpowruk River, USGS D2 (T).

\section{Genus NEPTUNEA Bolten (Roeding) 1798}

Neptunea sp. cf. N. elatior (Middendorff)

Plate 13, figure 7

This species occurs with $N$. leffingwelli but no intergradation is suggested by the specimens at hand. Neptunea elatior is generally taken to be the species represented by plate 10, figure 3 of Middendorff's Reise (1851). The author has seen no evidence to suggest that this form intergrades with carinated high-spired variety of $N$. ventricosa (see Middendorff, 1849, pl. 5, fig. $2 ; 1851$, pl. 8, fig. 1). Neptunea elatior has a super- 
ficial resemblance to Volutopsius beringi (Midden(lorff). However, it has a more constricted base, a recurving columella, and the suture is moderately appressed rather than low and incised as in V. beringi.

Localities: Colville River, USGS D305 (T).

\section{Neptunea leffingwelli (Dall)}

Plate 13, figures 1-4, 9

This form is known definitely only from localities on the Colville River. As stated by Dall, it does not correspond with any known Recent specimens of $N$. lyrata, an opinion that is borne out by the larger suite of specimens collected recently. If anything, the Colville River form is more closely related to a specimen from the Red Crag figured by Harmer (1915, pl. 17, fig. 4) as $N$. despecta decemcostata. However, neither are identical in the author's opinion with $N$. decemcostata (Say), a Recent species from the north Atlantic coast of America.

There is a tendency in $N$. leffingwelli for the development of elongate axial nodes or ribs which are symmetrical on some specimens but which, on other speciments, do not have a return slope on the sides of advanced growth but terminate as frilled varices. The spiral sculpture is variable.

An extremely variable complex of Neptunea varieties occurs in beds believed to be late Pliocene or early Pleistocene on Saint Paul Island. Members of this complex are similar either to $N$. lyrata or to most of the varieties of $N$. ventricosa. It is entirely possible that the Saint Paul complex is a hybrid series and that parts of it became more or less true-breeding varieties elsewhere; at least on Saint Paul the varieties are hopelessly confused. Some members of the Saint Paul complex approach $N$. leffingwelli and one may speculate that $N$. leffingwelli is an offshoot from the Saint Paul complex. Pyrulofusus schraderi (pI. 13, fig. 21), which occurs with $N$. leffingwelli on the Colville River, is known at only one other place-Saint Paul-where it occurs with the large Neptunea complex.

Localities: Colville River, USGS Tert. loc. 627 (Dall), USGS D305 (T), D306 (T).

\section{Neptunea ventricosa communis (Middendorff)}

Plate 14, figures 10, 12

This variety has a strong shoulder carina but there is no axial sculpture. Some specimens show one or two weak, shallow, discontinuous spiral depressions on the body whorl. The names fornicata (Reeve) and communis (Middendorff) both appear to apply to Recent forms from the coast of "Russian Lapland," al-

419591-57-3 though forms close to those figured by Middendorff (1849, pl. 5, figs. 3-6) occur in the Pliocene or Pleistocene of Saint Paul Island in Bering Sea. Middendorff also reports his variety as a fossil in the tundra of the Poluostrov Taymyr. Presumably the fossils from Poluostrov Taymyr are like a "subfossil" dredged by the Maud Expedition from near shore off Mys Chelyushkin, a point on the Poluostrov Taymyr. This specimen was figured by Løyning (1932, pl. 1, fig. 14) as Neptunea satura var. fornicata forma communis insignior (Middendorff). Another fossil from Novaya Zemlya was figured by Leche (1878, pl. 2, fig. 27) as Fusus fornicatus Reeve="Tritonium antiquum L., varietas communis (insignior; sculptura enodi)" Middendorff. The quotation was the legend for Middendorff's plate 5, figures 5 and 6 (1849).

Whether $N$. ventricosa communis Middendorff and $N$. ventricosa fornicato Reeve are distinct enough to be considered separate varieties is a matter of opinion. However, communis is recognized here for the variety in which the carina persists on the body whorl of adults (as in pl. 14, figs. 10,12), and fornicata for the variety in which it does not (see Tyron after Reeve, 1881, pl. 45 , fig. 251).

Neptunea despecta var. pumilia Harmer from the Icenian Crag has a strong shoulder carina, but it also has other well developed primary and secondary spirals. Harmer $(1914$, p. 166) states his variety resembles a Recent shell from Bering Sea labelled " $N$. fornicata var. multistriata", but that he did not regard them as identical. It is possible that he was comparing it with one of the varieties of $N$. lyrata.

Locality: Meade River, USGS Tert. loc. 15929.

\section{Neptunea ventricosa clarki (Meek)}

Plate 16, figures 13-14

This species was described from Skull Cliff, Peard Bay, about 40 miles southwest of Point Barrow, under the name of Chrysodomus clarki. Presumably the type was the only specimen found. It has a strong peripheral carina and a weaker primary spiral both above and below it. Between the primary spirals are slender spiral threads. This may be a monstrosity but it would be impossible to say without more specimens. A fragment from St. George (where there is a complex of varieties like that on Saint Paul) is close to the Skull Cliff specimen. It was reported by Dall (1919b) as Chrysodomus solutus cordatus n. var., apparently a nude name.

Localities: Skull Cliff, Peard Bay (Meek), Univ. Calif. loc. 3627. 
Neptunea ventricosa soluta (Heermann)

Plate 15, figures 13-14, 17-18; ? plate 16, figure 1; plate 17. figure 15

This variety is taken to include those shells having, in the young stages, a single strong spiral which breaks up early into well defined spirally elongate nodes. Neither carina nor nodes are well defined in adults. A Recent specimen of $N$. soluta from Saint Lawrence Island is shown on plate 17. Neptunea soluta has sometimes been recognized as a separate species, but a study of large numbers of fossil and Recent specimens indicates that it merges in some suites with typical $N$. ventricosa.

The specimens from the Kukpowruk River are all fragments. Some show a tendency to develop broad axials in the adult, approaching in this respect the variety $N$. ventricosa mesleri (Dall) from the Intermediate Beach at Nome (pl. 17, figs. 16, 17). This characteristic is not well developed on Recent specimens of soluta.

Neptunea ventricosa soluta could be derived from one of the varieties at Saint Paul (see p. 1); that shown on plate 17, figure 12. This form has one spiral more prominent than the others, and it tends to develop spirally elongate nodes. Elimination of the other weak spirals would produce a form similar to $N$. v. soluta.

Other specimens in the Saint Paul complex approach $N$. mesleri rather closely. Both Dall (1920) and MacNeil (MacNeil, Mertie, and Pilsbry, 1943) regarded $N$. mesleri as a Pliocene species. However, other paleontologists have suggested that the Nome beaches are Pleistocene deposits, and work done recently on glacial chronology supports this view.

Localities: Kukpowruk River, USGS D2 (T); ?Peard Bay, USGS Tert. loc. 1/1087; ?15 miles southwest of Point Barrow, USGS Tert. loc. 7229; ?Point Barrow, USGS Tert. loc. 15937.

\section{Neptunea ventricosa (Gmelin) \\ Plate 17, figure 14}

Typical Neptunea ventricosa is not present in known collections from the Gubik formation, but there is a strong suggestion that the variety $N$. ventricosa soluta may grade imperceptibly into typical $N$. ventricosa in living suites. Recent specimens examined from Saint Lawrence Island, both sides of the Seward Peninsula, and north to Wainwright (at the intersection of the Arctic coast with the 160th Meridian) show even gradations connecting several very characteristic end members and it seems to be impossible to plot them in a linear series. At least three and possibly five distinct varieties can be recognized. The specimen figured here (pl. 17, fig. 14) and one figured by Abbott (1954, pl. 24 , fig. $s$ ) come closest to being near the mean of the varietal series. Connected with them by smooth gradations are medium-high to high spired forms with a single strong spiral carina (see Middendorff, 1851, pl. 8, fig. 1; and Gray in Tryon, 1879-98, v. 3, pl. 46, fig. 256); lower spired forms with a single spiral which breaks up into spirally elongate nodes ( $N$. ventricosa soluta; pl 17, fig. 15) ; very low inflated forms with a pair of spirals (see Oldroyd, 1927, v. 2, pl. 27, figs. 1, 2-erroneously numbered 3,4$)$; inflated forms without spirals but with flaring growth varices $(N$. ventricosa variciferous; Dall, 1921, pl. 9, figs. 6, 7) ; and low inflated perfectly smooth forms ( $N$. ventricosa beringianus; Middendorff, 1849 , pl. 2 , figs. 3, 4). Some specimens of the latter are even lower and more inflated than Middendorff's figures. The Neptunea arthritica of Valenciennes (see Tyron, v. 3, pl. 47, fig. 262) has no prominent spirals but has sharp narrow axials that partly cross the subsutural slope and form a blunt node where they cross the shoulder. Some specimens in the Saint Paul complex have identical axials, but differ in having a spiral carina on the early whorls. Neptunea arthritica should be regarded as a variety of $N$. ventricosa.

No Recent specimens have been seen with axial ribs as strong as those of $N$. ventricosa mesleri (pl. 17, figs. 16,17 ), but some specimens of $N$. ventricosa soluta from the Kukpowruk River (pl. 15, figs. 14, 18) have strong axials and in all probability these varieties are very closely related.

Some individuals in the very variable Neptunea complex found in Pliocene or Pleistocene beds on Saint George and Saint Paul in the Pribilof Islands approach $N$. ventricosa; they are closest to the low inflated form with two prominent spirals figured by Martyn (see Oldroyd, 1927). One such fossil from Saint Paul was figured by Middendorff (1849, pl. 5, fig. 1; refigured by Tryon, v. 3, pl. 46, fig. 257).

An interesting contrast between the fossil Neptunea complex in the Pribilof Islands and the Recent N. ventricosa complex in the Bering Strait region is the presence in the former of individuals which are more similar to $N$. lyrata than to any living varieties of $N$. ventricosa (compare figs. 11 and 12, pl. 17). However, some specimens of $N$. ventricosa (pl. 17, fig. 14) bear a resemblance to the variety of $N$. lyrata which Dall named $N$. pribiloffensis, and to which the specimen figured on plate 17 , figure 13 is referable. It is probably too early to interpret these circumstances with any degree of certainty, but it makes an interesting speculation to assume that a northern species hybridized in the Pribilof region with an ancestor of the more southern $N$. lyrata, 
and that one of the results of this hybrid series was the extremely variable $N$. ventricosa.

There seems to be little doubt that $N$. lyrata is an indigenous Pacific type. There is nothing like this in the older Coralline Crag of England, but in the younger Red Crag forms similar to it as well as to varieties of $N$. ventricosa seem to be well established (see Harmer, 1914, pl. 17, figs. 6, 8). Neptumea decemcostata, the Recent species from the north Atlantic coast of America seems without question to have been derived from Pacific stock ( $N$. lyrata) such as the forms shown on plate 17, figs. 10 and 11 . Possibly $N$. decemcostata represents a separate migration of late date.

\section{Genus PYRULOFUSUS Mörch 1869}

Pyrulofusus schraderi Dall

Plate 13, figure 21

This species was described from the Gubik formation on the Colville River, presumably one of, or close to, the two localities from which fossils are here figured. This is a large dextral shell without spiral ribs, but with large rounded axial undulations that incline strongly towards the left ventrally. Two specimens of the same species are in a collection from Saint George in the Pribilof Islands. The species is otherwise unknown. Dall (1919b) listed the Saint George specimens as "Pyrulofusus sp. aff. harpa Mörch (dextral)". Pyrulofusus harpa is sinistral with strong spiral sculpture and coarse undulations that incline in the opposite direction (see Dall, 1921, pl. 7, only figure). If this is a dextral monstrosity it is more likely a monstrosity of $P$. deformis (Reeve) (see Leche, 1878, pl. 2, fig. 26).

The beds on Saint George (and Saint Paul) are late Pliocene or early Pleistocene. The beds along the Colville River are believed to be the oldest part of the Gubik formation and also of late Pliocene or early Pleistocene age. These two localities are the only known occurrences of $P$. schraderi, and as stated previously the extremely variable Neptunea complex found in beds on Saint Paul and Saint George contains individuals close to $N$. leffingwelli, described from the Colville River locality.

Localities: Colville River, USGS Tert. loc. 627 (Dall) ; Saint George, Pribilof Islands, USGS Tert. loc. 8277 (Dall).

\section{Genus BUCCINUM Linné 1758}

Buccinum physematum Dall Plate 13, figure 10

The only specimen found is a fragment of a well preserved spire. This appears to be the first fossil record of this species which Dall reports living from Dolphin and Union Strait to Bristol Bay, north of the Alaska Peninsula (see Dall, 1925a, pl. 4, fig. 5; Oldroyd, 1927, pl. 12, fig. 5).

See also $B$. angulosum var. (Oldroyd, 1927, pl. 5, fig. 1).

Localities: Colville River, USGS D306 ('T).

\section{Buccinum sp. aff. B. ochotense (Middendorff)}

Plate 13, figures 8,18

A single almost completely decorticated specimen is referred tentatively to this species, although it may actually be a variant of $B$. physematum. The few patches have retained a sculpture suggesting that shown in Middendorff's figure on plate 9, figure 5 (1851), but the overall aspect of the shell is not particularly like Middendorff's figures on plate 10, figures 1, 2 (1851), which have been taken by some authors as the original indication for $B$. ochotense. The latter is the B.ochotense Middendorff of Khomenko (1931, pl. 9, fig. 14). The figure with which the present specimen is compared is the form Middendorff designated as "variet. sculptura carinata".

Dall recognized $B$. ochotense in the Arctic Ocean north of Bering Strait as well as in the Sea of Okhotsk.

Localities: Colville River, USGS D306 (T).

\section{Buccinum plectrum Stimpson}

Plate 14, figure 11

Buccinum plectrum is a circumboreal species. In America it ranges south to the Gulf of Saint Lawrence and Puget Sound. It has been reported fossil from the Pribilof Islands (Saint Paul and Saint George), but the specimens are internal molds. Dall reported it from Unga Island, but I can find nothing in the Unga Island or Popof Island collections that could be so identified. A decorticated specimen figured by MacNeil (MacNeil, Mertie, and Pilsbry, 1943, pl. 10, fig. 22) from the Nome beaches could be this species. This species is sometimes confused with $B$. tenuae Gray which has finer, nearly straight axials.

Localities: Meade River, USGS Tert. loc. 15929.

\section{Buccinum angulosum Gray}

Plate 15, figures 15,16 ; plate 17 , figures 1,2

This species is reported by Dall to be living from Dolphin and Union Strait to Bering Strait. Middendorff $(1849$, pl. 7 , figs. 3,4$)$ and Leche $(1878$, p. 66$)$ reported it from Novaya Zemlya and "Russian Lapland." More recently Lфyning (1932, p. 10, pl. 1, figs. $9,10)$ identified two specimens from near the New Siberian Islands as this species, but added that Odhner does not concur in the identification. The author is not 
convinced that the identification of this species in the Asian Arctic is correct.

Meek identified a fossil from Peard Bay, Alaska, as $B$. normale Dall, a form which some authors regard as a variety of $B$. angulosum. The specimen was not figured.

This species exhibits considerable variation in the number of coarse spirals as well as in the strength of the basal angulation.

Localities: Kukpowruk River, USGS D2 (T) ; Point Barrow, USGS Tert. loc. 15937.

\section{Genus CoLUS Bolten (Roeding) 1798 \\ Colus (Aulacofusus) spitsbergensis (Reeve) \\ Plate 13, figure 15}

This species is circumboreal, ranging south to the Gulf of Saint Lawrence, the Strait of Juan de Fuca, and northern Japan. In spite of its wide Recent distribution it has turned up very rarely as a fossil. It occurs in the Nome beaches (MacNeil, Mertie, and Pilsbry, 1943, pl. 10, fig. 15), and Dall (1925a, p. 216) listed a C'olus (Aulacofusus) sp. cf. spitsbergensis from a boulder dredged from Georges Banks and dated it tentatively as Pliocene. Aside from these the author finds no other records of fossil occurrence.

The specimen from the Colville River is somewhat more inflated and has finer spiral sculpture than is common, but it can be matched with occasional Recent specimens.

Localities: Colville River, USGS D306 (T).

Genus PLICIFusus Dall 1902

Plicifusus aff. P. kroyeri (Möller)

Plate 13, figure 14

Two specimens from the Colville River locality are so identified. The axial ribs on the early whorls are not as well developed on the Colville River specimens as they are on Recent specimens of $P$. kroyeri. They persist until about the fourth whorl and are only clearly visable on a small nondecorticated patch on the third whorl on the reverse side of the specimen figured. The surface has irregular incised spiral lines.

Superficially this shell resembles two species of Colus (Aulacofusus); C. (A.) esychus Dall, which lives in the Arctic Ocean and reportedly off Bering Island, and $C$. (A.) herendeeni Dall, which is reported from the southern Bering Sea and Aleutian Islands. Neither species has axial ribs.

The author can find no reference to $P$. kroyeri having been found previously as a fossil.

Localities: Colville River, USGS D306 (T).

\section{Genus ANTIPLANES Dall 1902}

Antiplanes cf. A. perversa (Gabb)

Plate 13, figure 11

The finding of this genus, however poor the specimen, is of considerable interest inasmuch as it is not known to be living in the Arctic Ocean, and its occurrence on the Colville River seems to be clear evidence that during the late Pliocene or early Pleistocene some elements of the north Pacific fauna entered the polar sea. Antiplanes originated in the north Pacific and as far as is known all of the living and fossil species except this one are found in the north Pacific Ocean and Bering Sea. The single exception has been a specimen in a boulder dredged from the Banquereau Bank off Nova Scotia identified by Dall as "Antiplanes sp.? (Pacific genus)" (1925a, p. 215). Dall believed the boulder to be of Miocene or Pliocene age. This specimen, which was borrowed from the Peabody Museum of Yale University for study, is badly decorticated and not definitely determinable. In the author's opinion it is more probably a Colus, related to $C$. stimpsoni Mörch or $C$. pubescens Verrill.

Localities: Colville River, USGS D306 (T).

\section{Genus IORA Gistel 1848 \\ Lora skullcliffensis Meek \\ Plate 16, figure 15}

The specimen on which this species is based is not well preserved and its validity is in doubt. From collections made by Gilluly in 1923 along the Inaru and Topagoruk Rivers, Dall (in Smith and Mertie, 1930) identified a species without axial ribs as Lora laevigata Dall. However, these collections have not been located.

A bewildering number of species have been described from northern water under the generic names Lora and $B e l a$ and it seems likely that many of them are destined to synonomy. The situation is so confused at present that no stratigraphic significance is apparent.

Localities: Skull Cliff, Peard Bay (Meek), Univ. Calif. loc. 3627.

\section{PELECYPODA \\ Genus CHLAMYs Bolten (Roeding) 1798 \\ Chlamys hindsii (Carpenter) \\ Plate 14, figure 1}

Chlamys hindsii is very closely related to $C$. islandicus and is regarded as a variety or subspecies of it by some authors. It may be proper to regard it as a subspecies in the sense that it is not very distinct, but the author 
sees no evidence that it is a variety in the sense that in a given population specimens range from typical hindsii to typical islandicus. In the author's opinion hindsii is a distinct species.

In typical $C$. istandicus the riblets are coarser, quite evenly spaced, and either single or paired. In C. hindsii the central riblets of the right valve are bunched in raised groups of three, sometimes with weaker riblets between, but more often with smooth interspaces between the tripartite ribs. The young stages of hindsii may have smooth rounded ribs on the right valve which are stronger than the riblets of typical islandicus and which usually divide abruptly in the young adult stage into tripartite ribs in which the central riblet is stronger than the side riblets. The lateral extremities have less distinctive ribbing.

Chlamys hindsii is living from the Bering Sea to the Strait of Juan de Fuca. A fragment of a Chlamys figured by MacNeil (MacNeil, Mertie, and Pilsbry, 1943, pl. 12, fig. 4) from the Intermediate Beach at Nome probably is this species. The present record appears to be the first for this species north of Bering Strait, and it supports the evidence of some other species in the fauna from the Colville River that there was a migration from Bering Sea to the Arctic Ocean at that time.

Localities: Colville River, USGS D306 (T).

\section{Genus Astarte Sowerby 1816}

The cold water Astarte are a bewildering group of organisms. A multitudinous number of names has been applied to them, many appearing to have little value. In general, however, they seem to fall into some well defined groups made up of forms so closely related that it is difficult to say where one ends and the other begins. Some authors have attempted to reduce them to some half dozen or more species and placed all other names in the synonomy of these. The author is inclined to believe that the true picture can only be shown by applying trinomial, and in some cases quadrinomial names. Some local populations are extremely variable while the end members of other intergrading series appear to have geographic or stratigraphic significance. Probably no opinion would be worth much, however, until a monographic study is made of all of the Pliocene, Pleistocene, and Recent species.

Astarte cf. A. subequilatera Sowerby Plate 16, figures 2, 3

Hrdlicka (unpublished) collected several specimens from a locality on Peard Bay which compare closely with the north Atlantic species, A. subequilatera (see
Abbott, 1954, pl. 28, fig. o). The ventral margin of $A$. subequilatera is finely crenate, but the margin of the specimens from Peard Bay is not well enough preserved to show this character. This species is not present in any of the other collections from the Gubik formation now in the U.S. National Museum or the U. S. Geological Survey.

This species may be present in the Recent Alaskan fauna, but if so it has been combined with $A$. borealis by most authors. Typical $A$. borealis is a more inflated short trigonal form with its concentric undulations restricted to a small area near the beak. The specimen in the Leffingwell collection from Peard Bay which both Dall (1920, p. 26) and Meek (1923, p. 148) listed as $A$. borealis is the specimen figured on plate 16 , figures 5,6 of this paper and is here assigned to $A$. broweri Meek. Meek also listed $A$. borealis from Skull Cliff.

Localities: Peard Bay, USGS Tert. loc. 1/1087.

Astarte aff. A. fabula Reeve

Plate 16, figure 4; ?plate 16, figures 18, 19

A specimen that appears to be related to $A$. fabula occurs in beds along Peard Bay in association with several other forms. The beaks of $A$. fabula are located anterior of center and bend strongly to the posterior. The posterior end of the shell is longer than the anterior end and moderately broad. Concentric undulations of medium strength are present near the beaks and on some specimens extend nearly half way to the ventral margin. However, typical $A$. fabula is a more convex shell.

There are not enough specimens on hand to say definitely whether this form and $A$. broweri were part of an evenly grading series in the Gubik formation.

Middendorff's $A$. corrugata "forma transversa compressa" (1849 pl. 17, figs. 6, 7) appears to be closely related to $A$. broweri.

Localities: Peard Bay, USGS Tert. loc. 1/10187; ?Skull Cliff, Peard Bay (Meek), Univ. Calif. loc. 3627.

\section{Astarte broweri Meek}

Plate 13, figures 5, 6; plate 16, figures 5, 6, 16, 17, 20

This form was described as "Astarte arctica Gray; subspecies broweri" but in the author's opinion it is more properly a distinct species. The holotype, from Skull Cliff, is the specimen figured on plate 16, figures 16,20 . The shell is suboval, the beaks subcentral and low, and the concentric undulations are moderately fine and extend only about half of the distance to the ventral margin. On the specimen shown on plate 16, figures 5,6 the undulations occupy considerably less of the disc. 
There is some similarity between this form and one described from eastern Greenland by Posselt (1895, p. 71, pl. 1, figs. 8-11) under the name of $A$. borealis sericea. Posselt gave the distribution as circumpolar. Another specimen of undoubtedly the same form was figured from the same locality (Hekla Havn, east Greenland) by Jensen (1912, pl. 4, fig. 1f) as a "very elongated form" of $A$. borealis. If not identical, $A$. broweri and $A$. sericea are very similar and this particular element in the Gubik fauna appears to be a polar or north Atlantic derivitive rather than having come from the Bering Sea whence some other elements seem to have come.

Localities: Colville River, USGS D306 (T); Skull Cliff, Peard Bay (Meek), Univ. Calif. loc. 3627; ?Peard Bay, USGS Tert. loc. 7067.

\section{Astarte aff. A. vernicosa Dall}

Plate 15, figures 1-6; ?plate 17, figure 7

The form so designated may be an undescribed species, but, because an appropriate name may exist in the present complicated synonymy of related Astarte, it is not being named.

Astarte vernicosa was described from Icy Cape on the Arctic coast west of Point Barrow. The type is a young adult only 17 millimeters long. Although clearly related to $A$. fabula, and possibly a subspecies of it, $A$. vernicosa is smaller, has a thinner shell and a more delicate hinge. It is quite variable in shape, ranging from subquadrate to subtrigonal. The anterior ventral extremity in many specimens is subangulate. The fossils from Meade River appear to be identical with a fossil figured by Leche (1878, pl. 1, fig. 4d) from Novaya Zemlya as $A$. semisulcata var. withami Wood, but neither are the same as the heavy-hinged form from the English Crag figured by Wood (1853, pl. 16, figs. 3c-d) as $A$. borealis var. withami.

According to Dall, A. vernicosa ranges from the Arctic Ocean to the Aleutian Islands. It was not found in the Nome beaches and its occurrence in the Bering Sea should be checked. Soot-Ryen (1932, p. 13) identified a single valve dredged from just north of the New Siberian Islands as $A$. montagui var. vernicosa. It also seems likely that a specimen from western Greenland figured by Jensen (1912, pl. 4, figs. 1d-e) as $A$. borealis, "A strongly compressed form with distinct folds on the uppermost part of the shell", is this species.

With further collecting $A$. aff $A$. vernicosa and $A$. broweri may prove to be parts of an evenly grading series, but at the present time the author is inclined to doubt it.
Localities: Meade River, USGS Tert. loc. 15929; ?Point Barrow (a fragment), USGS Tert. loc. 15937.

\section{Astarte bennetti Dall}

Plate 15, figures 7, 8, 10, 11 ; plate 16 , figures 9,10

Astarte bennetti is a smaller species than $A$. fabula. It has about the same degree of twist to its beaks, but the shell is shorter and there are no concentric undulations on its beaks. The author has seen no indication that this species intergrades with $A$. fabula.

This species was described from Bennett Island north of the New Siberian Islands and is reported to be living in the East Siberian, Chukchi, and Beaufort Seas. Dall gives its southward range as Nunivak Island in Bering Sea. It was not found fossil in the Nome beaches. It appears to be a typically Arctic species and probably its Recent occurrence in Bering Sea needs checking.

Localities: Meade River, USGS Tert. loc. 15929; Peard Bay, USGS Tert. loc. 7067.

\section{Astarte leffingwelli Dall}

Plate 14, figures $17,18,20$; plate 16 , figures 7,11

Astarte leffingwelli is one of the characteristic species of the Pleistocene of Arctic Alaska and so far as is known it is extinct. It is listed as a Pliocene fossil by Dall and some other authors, but opinion at this date favors a Pleistocene age for all of its occurrences. It was not found at the Colville River localities which the author regards as being of possible late Pliocene age. It was found in the Intermediate Beach at Nome (MacNeil, Mertie, and Pilsbry, 1943, pl. 14, figs. 11, 12), now thought to be Pleistocene. This species also occurs in supposed Pleistocene deposits on Amchitka Island in the Aleutians.

Astarte leffingwelli is an elongated trigonal shell with prominent beaks and a well-developed lunule. Its surface is smooth or marked by concentric growth lines and occasional specimens have a few weak regular raised concentric undulations (pl. 14, fig. 20). Some specimens show an alternation of lighter and darker concentric bands, and a slight amount of decortication of normally smooth specimens etches the lighter bands more deeply than the darker bands, producing an effect which in photographs might be confused with original concentric undulations (see pl. 16, fig. 11).

Localities: Peard Bay, USGS Tert. locs. 7728 (type locality), 1/1087, 27067 (Dall-no specimen in this collection at present); Skull Cliff, Peard Bay (Meek), Univ. Calif. loc. 3627; Meade River, USGS Tert. loc. 15929. 


\section{Genus CARDITA Bruguière 1792}

Cardita (Cyclocardia) cf. crebricostata (Krause)

Plate 13, figures 19,20 ; plate 14, figure 13 ; plate 16 , figure 8

This species occurs at most of the localities along Peard Bay and judging from the contents of collections at hand it may be the most abundant species there. In collections from other areas it is represented by only one or two specimens or not at all.

Several very closely related species of $C y$ clocardia have been described from the north Pacific and Bering Sea but the writer is not convinced that all of them are valid. Among the specimens identified as $C$. $(C$. crebricostata in this report are individuals having from 19 to 25 ribs, but there seem to be no groupings that could be made on rib count alone. No specimen has as many ribs (28) as the extreme variety $C$. $(C$.) crebricostata nomensis, from the Nome beaches, named previously by the author (MacNeil, Mertie, and Pilsbry, 1943, p. 90, pl. 14, fig. 18). Most specimens in this series have a delicate incised radial microsculpture on top of the ribs, but occasional specimens lack it. The shape of the interspaces also ranges from shallow $\mathbf{V}$-shaped to $U$-shaped with no sharp demarcation between the two types.

The most likely ancestor of $C$. crebricostata is $C$. subtenta Conrad from the Astoria formation, middle Miocene, of Oregon and Washington (see Weaver, 1942, p. 140, pl. 33, fig. 7).

Localities: Colville River, USGS D306 (T) ; Meade River, USGS Tert. loc. 15929; Skull Cliff, Peard Bay (Meek, Univ. Calif. loc. 3627; Peard Bay, USGS Tert. locs. 1/1087, 7067; 15 miles southwest of Point Barrow, USGS Tert. locs. 7228, 7229; Amchitka Island, Aleutians, USGS D46 (T) ; Saint Paul Island, Pribilof Islands (Tom Barth collection) ; Nome, Inner Submarine Beach, USGS Tert. loc. 14865, Intermediate Beach, USGS Tert. locs. 5074, 7477, 14866, ?Second Beach, USGS Tert. loc. 3752.

Cardita (Cyclocardia) crassidens (Broderip and Sowerby)

Plate 14, figures 15, 16

This species has been reported living in the Chukchi and Beaufort Seas, Bering Sea, and the southern edge of the Aleutian Islands to Kodiak Island. It occurs as a fossil on Amchitka Island in the Aleutians, and is here recorded from the Meade River locality. Dall reported it in the Nome beaches but the form occurring there has only 7 to 10 ribs as opposed to 12 to 15 for known specimens elsewhere and it was described as a new species, $C$. $(C$.) subcrassidens, by MacNeil (MacNeil, Mertie, and Pilsbry, 1943, p. 90, pl. 15, figs. 1, 3).
Except for this character there appears to be little to distinguish it and it may be preferable to regard $C .(C$. subcrassidens as a subspecies of $C .(C$.$) crassidens.$

The presence of a species closely related to $C$. $(C$. crassidens in the middle and lower part of the Yakataga formation (Miocene and Pliocene?) along the northern Gulf of Alaska suggests strongly that this group had a Pacific origin. There appears to be nothing living or fossil in the Atlantic region like it.

Localities: Meade River, USGS Tert. loc. 15929; Amchitka, Aleutian Islands, USGS D46 (T); as subcrassidens, Nome, Inner Submarine Beach, USGS Tert. locs. ?7621, 14865, Intermediate Beach, USGS Tert. locs. 4538, 14866, Second Beach, USGS Tert. locs. 5078a, 7618.

\section{Genus SERRIPES Gould 1841}

\section{Serripes groenlandicus (Bruguière)}

Plate 14, figures 2,4 ; plate 16 , figure 12 ; plate 17 , figure 3

Serripes groenlandicus is now circumarctic and extends southward to England, Cape Cod, Puget Sound, and Hakodate, Japan. Pleistocene fossil records indicate that during that time it had about the same geographic range. Among its Pleistocene occurrences are Novaya Zemlya, the Red Crag of England, the Saint Lawrence valley, Greenland, the Canadian Arctic coast, Siberia, Alaska (including the Aleutian Islands), Vancouver, British Columbia, and Sakhalin.

Several authors have assumed a Pacific origin for this species, but the opinion seems to have been based for the most part on supposed Miocene occurrences in the Pacific region. Most of these are now thought to be Pliocene and Pleistocene. A specimen from Unga Island in the Shumagin Islands is a mold in a waterworn cobble of different rock than the beds on both Unga and Popof Islands, which contain a fauna still believed to be late Miocene. At the present time the antecedents of this species are not at all clear. It could be descended from a form like Cardium (Serripes?) hamiltonensis Clark (1932, pl. 18, figs. 6, 7) from the Poul Creek formation (middle and upper Oligocene) of the Yakataga district along the northern Gulf of Alaska.

Localities: Colville River, USGS D306 (T) ; Peard Bay, USGS Tert. loc. 1/1087; Point Barrow, USGS Tert. loc. 15937; Skull Cliff, Peard Bay (Meek), Univ. Calif. loc. 3627 .

\section{Genus MAc0MA Leach 1819}

Macoma calcarea (Gmelin)

Plate 14, figure 3 ; plate 15 , figure 9 ; plate 17 , figure 5

Macoma calcarea is one of the most widespread Arctic species and one that ranges farthest south. It is circumarctic, and is found as far south as Denmark, Long 
Island, Monterey, Calif., and northern Japan. Its Pleistocene distribution is similar.

The synonomy of this species is involved and it would be pointless to try to determine the subspecific or varietal value of any of the names applied to it without making a monographic study of the genus. The opinion expressed by several authors that this species originated in the Pacific seems to be justified. The author would hesitate to identify any Miocene form figured thus far as this species but it would be difficult to separate some Pliocene forms from it. The species does not appear in England until the Pleistocene (Red Crag). Its absence in the Carolline Crag was stressed by Wood (1857, p. 229).

Localities: Colville River, USGS D305 (T) ; Meade River, USGS Tert. loc. 15929; Skull Cliff, Peard Bay (Meek), Univ. Calif. loc. 3627; 15 miles southwest of Point Barrow, USGS Tert. loc. 7228; Point Barrow, USGS Tert. loc. 15937.

\section{Genus MYA Linné 1758}

Mya cf. M. arenaria Linné

Plate 17, figure 6

The place of origin and subsequent wanderings of Mya arenaria should be more obvious than they are. Most authors seem to have accepted without question that it originated in the Atlantic and migrated to the Pacific by way of the Arctic, some believing that it gave rise there to $M$. arenaria japonica. At present $M$. arenaria lives along the Atlantic coast from Laborador to North Carolina, and $M$. arenaria japonica lives in the Pacific from the Arctic Ocean to Monterey, Calif., and Japan.

Typical $M$. arenaria has been introduced in the San Francisco area and it has now migrated far north of there. Grant and Gale (1931, p. 413) in commenting on the form now living along the coast of Washington and British Columbia say,

if it be stated that they are representatives of the Atlantic coast form migrating northward from San Francisco, it can be answered that if so, they have in this short time come to look so much like their native brothers that in the course of a geologic age they would become indistinguishable, thus showing the nature of their differences to be like those of geographic varieties, not yet great enough to make them separate species.

The distribution of this species deserves much more study, but the author is inclined to believe that $M$. arenaria came from the Pacific. Mya arenaria japonica, or a closely related form, seems without question to occur in earlier beds in the Pacific than $M$. arenaria does in the Atlantic. Dall stated that $M$. arenaria occurs in the Yorktown formation (upper Miocene) of
Virginia, but W. C. Mansfield who studied the Miocene of Virginia more closely than anyone else does not mention it. According to Wood (1857, p. 280) the species does not occur in the Coralline Crag (Pliocene) but reached England first during the deposition of the Red Crag (Pleistocene). Dall (1924, p. 31) reported Mya intermedia Dall, a form regarded by some as a synonym of $M$. arenaria japonica (see Grant and Gale, 1931, p. 412), from two localities at Bernard Harbour, Dolphin and Union Strait, one of them being about 30 feet above sea level. This might be indicative that $M$. arenaria japonica migrated eastward along the Arctic coast in Pleistocene time.

Fragments of a $M y a$ were obtained from the Inner Submarine Beach, the Intermediate Beach, and the Second Beach at Nome (see MacNeil, Mertie, and Pilsbry, 1943, p. 93, pl. 16, fig. 3). It seems definitely to be an arenaria-like form; not the short $M$. truncata.

Localities: Point Barrow, USGS Tert. loc. 15937.

\section{Genus SPISULA Gray 1837}

Spisula cf. S. polynyma voyi (Gabb)

Plate 14, figure 5

"Callista" voyi Gabb is a California Pliocene fossil that most authors regard as identical with, and having priority in name over the Recent "Mactra" polynyma variety alaskana Dall. The latter also appears to be the S. grayana of Schrenck (see Khomenko, 1931, pl. 7, figs. 5-8). Gabb's name is a year older than Schrenck's, but if the fossil and Recent forms are again separated as subspecies, S. grayana is an older name for the latter. Judging from the best available figures the Recent Pacific form has a shorter posterior end and a longer anterior end than the Pliocene fossil form which has more central beaks and subsequal anterior and posterior ends. Probably the living Atlantic form, typical S. polynyma (Stimpson), compares more closely with the Pacific Pliocene fossils.

Both the specimen here figured from the Gubik formation and one figured by the author from the Nome beaches (MacNeil, Mertie, and Pilsbry, 1943, pl. 16, figs. 1,2) are elongate and appear to be more like " $C$." voyi (see Oldroyd, 1924, pl. 23) than specimens of Recent S. polynyma alaskana (Dall).

The east coast Spisula polynyma (Stimpson) ranges from Hudson Bay to Long Island Sound. Dall (1921, p. 51) gives the range of S. polynyma alaskana as Cape Lisburne, Alaska, to Puget Sound on the American side, and the Sea of Okhotsk to Japan on the Asiatic side. The species was not listed by Dall from anywhere along the Arctic coast of Canada in his report 
on the Canadian Arctic Expedition. However, its occurrence as a fossil on the Colville River partly substantiates a former distribution across Arctic North America.

The author finds no record of S. polynyma as a fossil in eastern North America and there is nothing in the east coast Tertiary closely related to it. It does not occur in the English Crag. However, it occurs at least as far back as the Pliocene in the Pacific and closely related forms are known from earlier horizons. The suggestion is strong that $S$. polynyma originated in the Pacific.

Localities: Colville River, USGS D306 (T).

\section{Genus SAXICAVA Fleuriau 1802}

Saxicava arctica (Linné)

Plate 14, figures 6,8 ; plate 15 , figure 12

There are few species having the range of Saxicava arctica. It ranges from the Arctic Ocean to the West Indies, and on the Pacific side to Panama. The southern records are mostly in deep water so that its habitat appears to be controlled partly by temperature.. It is a very common Arctic species and with $M$ ya truncata is the only species present in some far northern collections. Although it is generally thought to be circumarctic, Soot-Ryen (1932, p., 21) indicates that it does not occur in the East Siberian Sea and is not, therefore, truly circumarctic.

Soot-Ryen (1932, p. 25) lists S. artica as a species of probable Pacific origin. However, this is questionable. Of the Miocene occurrences of this species recorded by Dall (see Grant and Gale, 1931, p. 427) only one or two are still regarded as Miocene. Both Grewingk and Dall report Saxicava from Unga Island, but the genus is not present in the collections of Miocene fossils that Dall studied from Unga and Popof Island, (now in the U.S. National Museum). It may be that Grewingk found it in a post-Miocene bed on Unga Island. Hatai and Nisiyama (1952, p. 68) list one Pliocene occurrence of Hiatella (=Saxicava) in Japan but Weaver (1942) and Keen and Bentson (1944) do not list any Tertiary species at all from Washington and California. Saxicava arctica is reported throughout the Miocene of Maryland, however. The Maryland Miocene form has more terminal beaks and somewhat better defined hinge teeth than the Recent form and may actually be a different species (see Glenn, 1904, pl. 66, figs. 3-6) but there seems to be little room to doubt that it is the precursor of the Recent species. The species is common in the Coralline Crag (Pliocene) of England (see Wood, 1857, pl. 29).
Saxicava arctica was obtained at four stations along the Canadian Arctic coast by the Canadian Arctic Expedition (Dall, 1924, p. 30-32) but not so commonly as $S$. pholadis. It occurs in the Inner Submarine Beach, the Intermediate Beach, and the Second Beach at Nome (MacNeil, Mertie, and Pilsbry 1943, p. 93, pl. 15, fig. 16).

Localities: Colville River, USGS D305 (T), D306 (T) ; Meade River, USGS Tert. loc. 15929.

Saxicava pholadis (Linné)

Plate 15 , figure 20 ; plate 17 , figure 8

According to some authors this is merely a variety of $S$. arctica but even if this is so the name would have value in designating the end member of an extremely variable series. Apparently it has the same geographic range as $S$. arctica; a strong reason for believing them to be identical.

Dall lists it from ten localities along the Canadian Arctic coast, three of the localities being 250,300, and 320 feet above sea level, respectively. All ten localities were believed to be Pleistocene. It also occurs in the Intermediate Beach and the Second Beach at Nome (MacNeil, Mertie, and Pilsbry 1943, p. 94, pl. 15, figs. $11,13)$.

Localities: Kukpowruk River, USGS D2 (T) ; Point Barrow, USGS Tert. loc. 15937; Skull Cliff, Peard Bay (Meek), Univ. Calif. loc. 3627.

\section{Genus CYRTODARIA Daudin 1799 \\ Cyrtodaria kurriana (Dunker) \\ Plate 14, figures 7, 9}

Cyrtodaria kurriana is a circumarctic species, scarcely extending into boreal waters, if at all. On the Pacific side it is reported only as far south as Norton Sound in northern Bering Sea and on the Atlantic side in Greenland waters. It was reported in the Pleistocene of Herschel Island, Northwest Territories, Canada, by Dall $(1924$, p. 32 ) and according to Soot-Ryen (1932, p. 28) the species occurs in the Coralline Crag (Pliocene) of England. It also occurs in the Icelandic Crag (Soot-Ryen, 1932, p. 28). Both of the Crag records are based on specimens identified as $C$. siliqua; Soot-Ryen believing both to be $C$. Kurriana. Cyrtodaria siliqua Spengler is a more southerly species, ranging on the Atlantic coast from Labrador to Rhode Island. Since the Coralline Crag is supposed to have undoubted southern relationships, Soot-Ryen's interpretation is surprising.

Localities: Colville River, USGS D306 (T). 


\section{CIRRIPEDIA}

\section{Genus BaLavios Da Costa 1778}

Balanus rostratus alaskensis Pilsbry

Plate 14, figure 19 ; plate 17 , figure 4

This identification is Dall's. This same subspecies was identified by Pilsbry from the Nome beaches (see MacNeil, Mertie, and Pilsbry, 1943, pl. 15, fig. 10, pl. 16, fig. 16). The figured specimen from Nome lacks the coarse external ribs, but other specimens in the Nome beaches are identical with the ones figured here from the Gubik formation.

Localities: Peard Bay, USGS Tert. loc. 7228; Meade River, USGS Tert. loc. 15929.

\section{Balanus sp.}

Plate 13, figure 4

Several specimens of a small coarsely striated Balanus are attached to specimens of Neptunea leffingwelli. A cluster of five plus several basal plates occurs on one unfigured specimen. The large figured specimen ( $\mathrm{pl}$. 13, fig. 4) bears one.

Iocalities: USGS D306 (T).

\section{UNIDENTIFIED WORM TUBES}

Plate 14, figure 1

Specimens of a small, closely coiled worm tube encrust the surface of the figured specimen of Chlamys hindsii and an unfigured specimen of Neptunea leffingwelli. The first turn is plane coiled, the second turn superimposed on the first. The coiling habit suggests that it is a different worm than those found in Dall's Nuwok formation.

Localities: USGS D306 (T).

\section{DESCRIPTIONS OF NEW SPECIES \\ Genus NUCLANA link 1807 \\ Nuculana morrisi, n. sp. \\ Plate 11, figure 3}

Shell of medium size for the genus, sharply rounded anteriorly but moderately blunt and definitely not attenuated posteriorly. The beaks are low and situated at about four-sevenths the distance from the posterior end. Anterior dorsal margin weakly convex, posterior dorsal margin very weakly concave or straight. The posterior part of the shell has a well-defined nearly straight dorsal truncation just below the dorsal margin and a weaker angulation, also nearly straight or very slightly curved extending in the posteroventral direction, the two forming a weak but broad flattened or weakly sulcate area between them. The sculpture con- sists of sharp raised concentric lirations which, on the anterior side, have a steeper dorsal slope and a ramplike ventral slope, but which are higher, narrower, and nearly symmetrical on the posterior side. Some of the lirations cross the dorsal truncation but the number varies from adjacent lirations to every other to every third; those not crossing the dorsal truncation die out abruptly just ventral to it. Hinge not seen.

Holotype: USNM 561865.

Dimensions: Length, 16.8 millimeters; height, 7.6 millimeters.

This species is probably related to $N$. washingtonensis (Weaver) (see Weaver, 1942, pl. 8, fig. 26) but differs in having a shorter and narrower anterior end and a broader, less attenuated posterior end. Both posterior angulations of $N$. washingtonensis are strongly curved with the convexity on the dorsal side, and the sulcation between them is narrower and likewise curved. In $N$. morrisi the posterior angulations are nearly straight, the enclosed area is flat or only weakly sulcate and about twice as broad as the sulcation in $N$. washingtonensis.

Horizon: Miocene?

Type locality : Carter Creek, a stream flowing into Camden Bay, Arctic coast of Alaska. About latitude $69^{\circ} 57^{\prime} 45^{\prime \prime} \mathrm{N}$., longitude $144^{\circ} 46^{\prime} \mathrm{W}$. From an interval 210 to 258 feet below the top of a measured section. Collector, Robert H. Morris, 1953. Locality, USGS D50 (T).

\section{Genus CHLAMYs Bolten (Roeding) 1798}

Chlamys nuwokensis, n. sp.

Plate 11, figures 4-6, 12

Shell of medium size, suborbicular; valves very little inflated, very thin and translucent. Dorsal margins concave, the posterior margin a little more so than the anterior margin and terminating in a line more nearly horizontal. Posterior margin of posterior ears strongly sloping; anterior margin of anterior ear of left valve about vertical; anterior ear of right valve incomplete on only known specimen but apparently alate with a moderate byssal sinus. Dorsal margin along byssal sinus bearing strong denticles. No well-defined submarginal areas. Sculpture similar on both valves but ribs on right valve may be slightly broader at the crest. Nine well-formed ribs on each valve and on some individuals another incipient rib at either end or both ends. Ribs narrow and some bluntly rounded on top, separated by broad evenly concave interspaces that rise gently to the crest of the ribs. Secondary radial lirations in the interspaces, and in individuals whose ribs are not flattened on top they may be present on top of the ribs as well; 8 to 14 secondary radial lirations 
in each interspace. The alate anterior ear of the right valve with 3 to 4 strong radials; all other ears sculptured with fine lirations similar to the secondary lirations on the disc but sometimes made beaded by growth lines. Raised slightly irregular concentric lamellae extend across the crest of the ribs and on the secondary radial lirations form tiny upright crescentic spines, but there is no suggestion of a metal lathlike sculpture of the type found in the $C$. istandicus group. The ligament pit is shallow and inclined slightly to the posterior.

Holotype: A left valve (fig. 4), USNM 561866. Paratypes: left valve (fig. 5), USNM 561867, left valve (fig. 6) USNM 561868, right valve (fig. 12), USNM 561869 .

Dimensions of holotype: length, 60 millimeters.

The relationships of this species are by no means clear. The concave dorsal margins, scabrous surface and rib pattern recall $C$. sayanus Dall from the Miocene of Florida (see Tucker-Rowland, 1938, pl. 2, fig. 6). Another possibly related species which has primary ribs only near the beaks, but which has a thin translucent shell like $C$. nuwokensis occurs in the Miocene of Virginia; $C$. virginianus (Conrad) (see Tucker-Rowland, 1938, pl. 5, fig. 14).

The ribbing of $C$. nuwokensis at least superficially resembles that of the left valve of Fortipecten hallae (Dall) from the Pliocene or Pleistocene of Nome, Alaska (see MacNeil, Mertie, and Pilsbry, 1943, pl. 12, fig. 1), but the latter is a moderately heavy shell and the sculpture of the right valve is quite different. Moreover, $F$. hallae has a metal lathlike microsculpture. Fortipecten also occurs in the Pliocene of Japan (see Yabe and Hatai, 1940). Pecten kagamianus Yokoyama, 1929, pl. 1, fig. 1) is a possible relative of both $C$. nuwokensis and $F$. hallae but, if so, it is impossible at this time to say how closely and through what intermediate species they are related.

Horizon: Miocene (?).

Type locality: Carter Creek, a stream flowing into Camden Bay, Alaska. About latitude $69^{\circ} 57^{\prime} 45^{\prime \prime}$ N., longitude $144^{\circ} 46^{\prime} \mathrm{W}$. From a section 210 to 258 feet below the top of a measured section. Collector, Robert H. Morris, 1953. Locality, USGS D50 (T).

\section{LIST OF LOCALITIES}

[Area location, in parenthesis, shown in figure 48]

University of California locality :

3627. Skull Cliff, a sea cliff 70 to 80 feet high, located along Peard Bay about 40 miles southwest of Point Barrow. The sea cliff between this point and Point Barrow maintains a height of about 25 feet. Fossils obtained from upper 25 feet of Skull Cliff. Charles E. Meek, collector.
U. S. Geological Survey (Washington; Tertiary locality number) :

627. Bluff of the Colville River at about the 70th parallel, about 40 miles up the Colville River from its mouth. F. C. Schrader, collector. (2)

1/1087. From ice and snow ravines in mud bluff facing Peard Bay about 30 miles southwest of Point Barrow. A. Hrdlicka, collector. (6)

7067. Peard Bay, about 30 miles southwest of Point Barrow, from top of high bank. E. de K. Leffingwell, collector. (6)

7068a. Carter Creek, 1 mile from the Arctic coast at Camden Bay, in fine consolidated silt from top of section to 30 feet below. E. de K. Leffingwell, collector. (1)

7068b. Same locality, but a collection from 30 feet below the top of the section kept separate. E. de $K$. Leffingwell, collector. (1)

7069. Carter Creek, 100 yards east of 7068 and 80 feet below it. E. de K. Leffingwell, collector. (1)

7070. Carter Creek, 200 yards east of 7069 and 100 feet below it. E. de K. Leffingwell, collector. (1)

7228. Fifteen miles southwest of Point Barrow along the coast; taken from talus below the bluff. E. de $\mathbf{K}$. Leffingwell, collector. (7)

7229. Same place as 7228 but taken in place from the bluff. E. de K. Leffingwell, collector. (7)

7230. Carter Creek, Camden Bay, Arctic coast. G. C. Martin, collector. (According to Leffingwell $7230=$ 7068.) (1)

7231. Carter Creek, Camden Bay, Arctic coast. G. C. Martin, collector. (According to Leffingwell $\mathbf{7 2 3 1}=$ 7070.) (1)

15929. Arctic coastal plain-Meade River at latitude $70^{\circ} 30^{\prime}$ N. L. J. Barksdale, collector. (4)

15937. From a gravel terrace, Point Barrow, Alaska. L. J. Barksdale, collector. (8)

U. S. Geological Survey (Denver; Tertiary locality number) :

D2 (T). Isolated cut bank, east side of Kukpowruk River, latitude $69^{\circ} 21^{\prime}$ N., longitude $162^{\circ} 48^{\prime} \mathrm{W}$., about 20 miles south of Point Lay, Alaska. E. G. Sable, collector. (5)

D48 ( T). Carter Creek, a stream fiowing into Camden Bay, Alaska; a sharp bend in the creek at about latitude $69^{\circ} 57^{\prime} 45^{\prime \prime} \mathrm{N}$., longitude $144^{\circ} 46^{\prime} \mathrm{W}$. Section measured along creek and adjoining draws. Fossils from upper 50 feet of measured section. R. H. Morris, collector. (1)

D49 (T). Same section. Fossils from interval 110 to 210 feet below top of measured section. R. H. Morris, collector. (1)

D50 (T). Same section. Fossils from interval 210 to 258 feet below top of measured section. R. $H$. Morris, collector. (1)

D51 (T). Same section. Fossils from interval 258 to 266 feet below top of measured section. R. H. Morris, collector. (1)

D52 (T). Same section. Fossils from talus; position unknown. R. H. Morris, collector. (1)

D305 (T). Colville River at mouth of Kikiakrorak River. K. Stefansson, collector. (2)

D306 (T). Colville River at Ocean Point, about 8 miles be low mouth of Kikiakrorak River. K. Stefansson, collector.

(2) 


\section{LITERATURE CITED}

Abbott, R. T., 1954, American seashells: D. Van Nostrand Co., Inc., New York.

Albrecht, J. C. H. and Valk, W., 1943, Oligocäne Invertebraten von Süd-Limburg: Meded. von de Geol. Stichting, ser. C, v. 4 , pt. 1 , no. 3 .

Clark, B. L., 1932, Fauna of the Poul and Yakataga formations (upper Oligocene) of southern Alaska: Geol. Soc. America Bull., v. 43, no. 3, p. 797-846.

Dall, W. H., 1903, Synopsis of the family Astartidae with a review of the American species: U. S. Natl. Mus. Proc., v. 26, no. 1342.

1919a, Mollusks, Recent and Pleistocene: Report of the Canadian Arctic Expedition 1913-18, v. 8, pt. A, Ottawa. $1919 b$, On some Tertiary fossils from the Pribilof Islands: Washington Acad. Sci. Jour., v. 9, no. 1, p. 1-3. 1920, Pliocene and Pleistocene fossils from the Arctic coast of Alaska and the auriferous beaches of Nome, Norton Sound, Alaska: U. S. Geol. Survey Prof. Paper 125-C, p. 23-37.

- 1921, Summary of the marine shellbearing mollusks of the northwest coast of America, etc. : U. S. Natl. Mus. Bull. 112. 1924, Report of 'Tertiary and Quaternay fossils from the Canadian Arctic coast in O'Neill, J. J., Report of the Canadian Arctic Expedition 1913-18, v. 11, pt. 4A, Ottawa p. 27-28, 30-33.

Dall, W. H., 1925a, Illustrations of unfigured types of shells in the collection of the United States National Museum: U. S. Natl. Mus. Proc., v. 66, art. 17.

1925b, Tertiary fossils dredged off the northeastern coast of North America: Am. Jour. Sci., 5th ser., v. 10, p. 213-218.

Glenn, L. C., 1904, Pelecypoda: Md. Geol. Survey, Systematic Palentology; Miocene.

Grant, U. S. IV, and Gale, H. R., 1931, Catalogue of the marine Pliocene and Pleistocene Mollusca of California: San Diego Soc. Nat. History Memoirs, v. 1.

Gryc, G., Patton, W. W. Jr., and Payne, T. G., 1951, Present Cretaceous stratigraphic nomenclature of northern Alaska: Washington Acad. Sci. Jour., v. 41, no. 5, p. 159-167.

Hagg, R., 1927, A new Tertiary fauna from Spitsbergen: Upsala Univ., Geol. Inst., Bull., v. 20, article 2.

Harmer, F. W., 1914, The Pliocene Mollusca : Paleontographical Soc. London, v. 67, no. 4.

-__ 1915, The Pliocene Mollusca: Paleontographical Soc. London, v. 68, no. 1 .

- 1921, 'The Pliocene Mollusca: Paleontographical Soc. London, v. 73, no. 1.

1923, The Pliocene Mollusca: Paleontographical Soc. London, v. 75, no. 1.

Hatai, K. M., 1940, The Cenozoic Brachiopoda of Japan : Tōhoku

Imp. Univ. Sci. Repts., 2d ser. (Geology), v. 20.

Hatai, K. M., and Nisiyama, S., 1952, Check list of Japanese Tertiary marine Mollusca : Tōhoku Imp. Univ. Sci. Repts., $2 d$ ser. (Geology) Special v. 3.

Heering, Jan., 1950, Pelecypoda (and Scaphopoda) of the Pliocene and older-Plistocene deposits of the Netherlands : Meded. von de Geol. Stichting, ser. C, v. 4, pt. 1, no. 9 .

Jensen, Ad. S., 1912, Lamellibranchiata, Pt I: The Danish Ingolf-Expedition, v. 2, pt. 5. København.

Keen, A. M. and Bentson, H., 1944, Check list of California Teritary marine Mollusca: Geol. Soc. America, Special paper no. 56.
Khomenko, J., 1931, Materials on the stratigraphy of the Tertiary beds of the eastern Sakhalin oilfield: Geol. and Prospecting Service of U.S.S.R., Trans., Fasc. 79.

Leche, W., 1878, Öfversigt öfver de af Svenske Expeditionerna till Navaja Semlja och Jenissej 1875 och 1876 insamlade Hafs-mollusker: K. Svenska vetensk.-Akad. Handl., Bd. 16, no. 2.

Leffingwell, E. de K., 1919, The Canning River region, northern Alaska : U. S. Geol. Survey Prof. Paper 109.

L $\varnothing$ yning, P., 1932, Loricata and Gastropoda from the Siberian Arctic coast: Norwegian North Polar Expedition with the "Maud" 1918-1925, Sci. Results, v. 5, no. 14.

MacNeil, F. S., Mertie, J. B., and Pilsbry, H. A., 1943, Marine invertebrate faunas of the buried beaches near Nome, Alaska : Jour. Paleontology, v. 17, no. 1, p. 69-96.

Meek, C. E., 1923, Notes on stratigraphy and Pleistocene fauna from Peard Bay, Arctic Alaska: Calif. Univ., Dept. Geol. Sci., Bull., v. 14, no. 13, p. 409-422.

Middendorff, A. Th. von, 1849, Malacozoologia Rossica : L'Acad. Imp. Sci. Saint-Petersbourg Mem., ser. 6, v. 6.

Middendorff, A. Th. von, 1851, Reise in den Äussersten Norden und Osten Siberiens : K. Akad. Wiss., Band. 2, Teil 1 (Mollusken). Saint-Petersbourg.

Morris, P. A., 1947, A field guide to the shells : Riverside Press, Cambridge, Mass.

Nicol, D., 1951, Recent species of the veneroid pelecypod Arctica: Washington Acad. Sci. Jour., v. 41, no. 3.

Oldroyd, I. S., 1924-25, The marine shells of the west coast of North America: Stanford Univ. Pubs., Geol. Sciences, v. 1,1924 ; v. 2 , pts. $1-3,1927$.

O'Neill, J. J., 1924, The geology of the Arctic coast of Canada west of the Kent Peninsula: Canadian Arctic Expedition, 1913-18, Rept. v. 11, pt. A.

Payne, T. G. and others, 1951, Geology of the Arctic slope of Alaska : U. S. Geol. Survey Oil and Gas Inv. Map, OM 126.

Posselt, H. J., 1895, Östgrønlandske Mollusker : Meddelelser om Grønland, v. 19, no. 2.

Ravn, J. P. J., 1922, On the Mollusca of the Tertiary of Spitsbergen: Skrifter om Svalbard og Ishavet, Bind 1, no. 2, Oslo.

Sars, G. O. 1878, Mollusca Regionis Arcticae Norvegiae: Universitets-program, 1878, Christiania.

Schrader, F. C., 1904, Reconnaissance in northern Alaska : U. S. Geol. Survey Prof. Paper 20.

Slodkevich, V. S., 1935, The molluscan fauna of the Pleistocene deposits of the Lawrence Bay coast: Soc. Natl. Leningrad (Sec. Geol. et Minér). Trans., v. 64, lv. 1, p. 112-122.

Smith, P. S. and Mertie, J. B., Jr., 1930, Geology and mineral resources of northwestern Alaska: U. S. Geol. Survey Bull. 815.

Soot-Ryen, T., 1932, Pelecypoda with a discussion of possible migrations of Arctic pelecypods in Tertiary times: Norwegian North Polar Expedition with the "Maud" 1918-1925, Sci. Results, v. 5, no. 12.

Taki, I. and Oyama, K., 1954, The Pliocene and later faunas from the Kwanto Region in Japan: Japan Palaeontological Soc., Special papers no. 2., p. 1-68.

Tryon, G. W., (Pilsbry, H. A. and Sharp, B.), 1879-98, Manual of conchology, v. 1-17: Phila. Acad. Sci.

Tucker-Rowland, H. I., 1938, The Atlantic and Gulf Coast Tertiary Pectinidae of the United States: Mus. royal d'histoire nat. de Belgique Mem., 2 ser. fasc. 13. 
Weaver, C. E., 1942, Paleontology of the Marine Tertiary formations of Oregon and Washington: Wash. Univ. Pub. in Geology, v. 5, pts. 1-3.

Wood, S. V., 1851, The Crag Mollusca: Paleontographical Soc. London, $\nabla .4$, no. 1.

1853, The Mollusca of the Crag: Paleontographical Soc. London, v. 7, no. 5.

1857, The Mollusca of the Crag: Paleontographical Soc. London, v. 9, no. 1.

Yabe, H. and Hatai, K. M., 1940, A note on Pecten (Fortipecten, subg. nov.) takahashii Yokoyama and its bearing on the
Neogene deposits of Japan : Töhokı Imp. Univ. Sci. Repts., 2d ser. (Geology), v. 21, no. 2.

Yabe, H. and Nomura, S., 1925, Notes on Recent and Tertiary species of Thyasira from Japan: Tõhoku Imp. Univ. Sci. Repts., 2d ser. (Geology), v. 7, no. 4.

Yokoyama, M., 1920, Fossils from the Miura Peninsula and its immediate north: Tokyo Imp. Univ. College Sci. Jour., v. 39, art. 6, p. 1-193, pls. 1-20.

1929, Pliocene shells from near Nanao, Noto: Imp. Geol. Survey, Japan, Rept. 104. 



\section{N D EX}

[Italic numbers Indicate description]

A

Page

abyssorum, Periploma Abstract......................... 99

Admete regina ............ 101 affinis, Natica alaskana, Mactra polynyma.................. 118 Spisula polynyma alaskensis, Balanus rostratus..-.-. 110, 120, pls. 14, 17 Scaphander........................... 103 aleutica, Natica........... 109 altus, Anomalosipho ...................... 103 andersoni, Neptunea................................. 17 angulosum, Buccinum....... 110, 113-114, pls. 15, 17

Anomalosipho allus - 103 sp................... 102, 109, pl. 12 Antiplanes perversa............... 110, 114, pl. 13

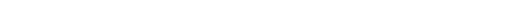
arcica, Astarte-_....................... 105 broweri, Astarte........................ 115 Saxicava Thyasira Arctica carteriana................. 102, 105, 106, pl. 12

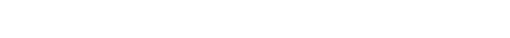
ovata......... 105 arcticus, Cadulus_............... 102, 107, pl. 12 arenaria, Mya japonica, Mya arthritica, Neptunea Astarte arctica. ....... 105 arctica broweri bennetti................... 110,116, pls. 15, 16

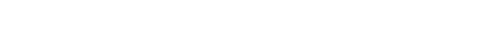

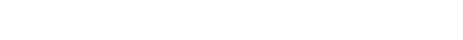
withami $\ldots \ldots \ldots$ broweri carteriana............... 105 concentrica crenata fabula................... 105, 110,115, 116, pl. 16 galeotti_................ 105 gracilis_................................. 105 incerta laurentiana.--

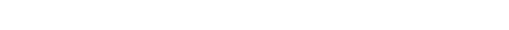
martini . _._._................. 102, 105, pl. 12 montagui vernicosa................ 116 polaris_.................. 105 semisulcata withami subequilatera..................... 110,115, pl. 16 sulcata vernicosa_................ 105, 110, 116, pls. 15, 17 sp....................... 102, 105, pls. 11, 12

(Aulacofusus) esychus, Colus---_...-... 114 herendeeni, Colus_................... 114 spitsbergensis, Colus............ 110, 114, pl. 13

\section{B}

Balanoides, Balanus.................. 102, 108, pl. 12 Balanus balanoides................ 102, 108, pl. 12 crenatus................... 102, 108, pl. 12 rostratus alaskensis_........... 110, 120, pls. 14, 7

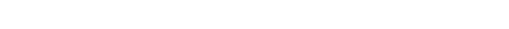

bennetti, Astarte............... 110,116, pls. 15, 16 beringi, Volutopsius........................ 110-111 beringianus, Neptunea ventricosa ............. 112 bisecta, Thyasira ............................ 106

borealis, Astarte.............................. 115 Cardita

Lunatia ............................... 103

sericea, Astarte......................... 116

withami, Astarte........................ 116

Brachiopoda broweri, Astarte .......... 110, 115-116, pls. 13, 16 Astarte arctica......................... 115

Buccinum angulosum ....... 110, 118-114, pls. 15, 17 normale ochotense............................ 110 13 physematum plectrum_.................. 110, 119, pl. 14 tenuae sp.................. 102, 109

\section{0}

Cadulus arcticus.................. 102, 107, pl. 12 calcarea, Macoma $102,106,110,117-118$, pls. $14,15,17$ $\begin{array}{lll}\text { californianus, Mytilus.-_..................... } & 104 \\ \text { californicus, Laqueus } & 108\end{array}$ californicus, Laqueus.-..................... 108 camdenensis, Cyrtodaria _._._._._. 102, 107, pl. 12

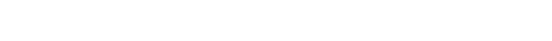
crebicostata_._. subtenta_- 117 (Cyclocardia) crassidens_........ 110, 117, pl. 14 crebicostata......... 110, 117, pls. 13, 14, 16 crebicostata nomensis.................. 117 nuwokensis_............... 102, 105, pl. 12 subcrassidens...-.................. 117

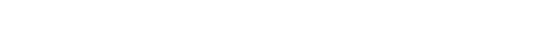
(Serripes) hamiltonensis_............... 117 carteriana, Arctica._......... 102, 105, 106, pl. 12 Astarte ................................ 105

Chlamys hindsii.......... 110, 114-115, 120, pl. 14 islandicus . - . - . - . . nuwokensis...... 102, 104, 108, 120-121, pl. 11 zone sayanus. .............................. 104, 121 virginianus

Chrysodomus clarki_..................... 111 solutus cordatus ........... 111 ciliatum, Cardium__._._._._._._._... 109 Cirripedia, of Gubik formation.............. 120 of Nuwok formation ................... 108

clarki, Chrysodomus.................... 111

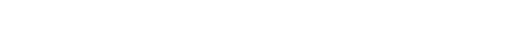
clausa, Nautica .......................... 109,110 Natica (Cryptonatica) _............. 109, pls. 13,15 Colus pubescens............................ 114 stimpsoni (Aulacofusus) esychus.................... 114 herendeeni..................... 114 spitsbergensis_............... 110,114, pl. 13 sp _............ 102, 103, pl. 12 communis, Neptunea ventricosa ........ 110,111, pl. 14 concentrica, Astarte...................... 105 conradi, Scaphander -103 consors, Natica .............................. 109 cordarus, Chrysodomus solutus_.............. 111 crassa, Emarginula .................. 102-103 Crassatellites.............................. In5 crassidens, Cardita (Cyclocardia) _....... 110, 117, pl. 14 creticostata, Cardita ....................... 105

Cardita (Cyclocardia) ....... 110, 117, pls. 13, 14, 16 nomensis, Cardita (Cyclocardia) ............ 117 crenata, Astarte crenatus, Balanus.................... 102, 108, pl. 12 (Cryptonatica) clausa, Natica............ 109, pls. 13. 15 cuneiformis, Martesia _.................. 107 (Cyclocardia) crassidens, Cardita. ....... 110, 117, pl. 14 crebicostata, Cardita........ 110,117, pls. 13,14, 16 nomensis, Cardita................... 117 nuwokensis, Cardita................ 102, 105, pl. 12 subcrassidens, Cardita.
Page

Cyrtodaria camdenensis ................. 102, 107, pl. 12 kurriana

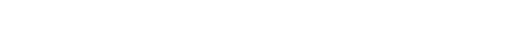
sp....................................... pl.11 D, E

decemcostata, Neptunea Neptunea despecta........................ 111 deformis, Pyrubofusus....................... 113 despecta decemcostata, Neptunea............... 111 pumilia, Neptunea devexa, Thracia truncata.................... 106 disjuncta, Thyasira.......................... 106 dorsalis, Xylophaga 107 elatior, Neptunea ......................... 110 13

Emarginula crassa ....................... 102, 103

fasciculata......................... 101-102 gabli marylandica. ........................ 101-102 nystiana .................. 101-102, 103 (Subemarginula) vadososinuata .......... 101, 103 yatesii ......... 101, 102, 103, 108, pl. 11

Emerson, W. K., quoted .................. 107 erosus, Tachyrhynchus _............. 109 major, Tachyrhynchus_... ........ 109, 110, pl. 13 esychus, Colus (Aulacofusus) ................ 114

fabula, Astarte _.............. 105,110, 115, 116, pl.16 fasciculata, Emarginula ................... 101-102

Faunal zones, list of .............. 100

Faunules, list of

flexuosa, Thyasira ..._................... 106

fornicata multistriata, Neptunea.............. 111

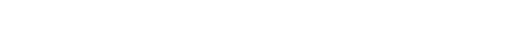

Fortipecten hallae ........................... 104, 121

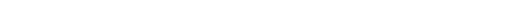

takahashii_............................. 104 fragilis, Periploma.................... 102, 106, pl.11

G

gabbi, Emarginula galeotti, Asiarte _.......................... 105

Gastropoda, of Gubik formation..........- 109-114 of Nuwok formation gouldii, Thyasira _..._....................... 106 gracilis, Astarte grandis, Terebratula.......................-. 108 grayana, Spisula groenlandica, Lunatia groenlandicum, Palliolum............. 102, 104, pl. 11 groenlandicus, Serripes ... 100, 110, 117, pls. 14, 16, 17 Gubik formation, description............ 100 megafossils of ....................... 108-120

H-K

hallae, Fortipecten hamiltonensis, Cardium (Serripes)_..._....... 117 harpa, Pyrulofusus ...................... 113 herendeeni, Colus (Aulacofusus) ............... 114 hesperianus, Mytilus_..................... 104

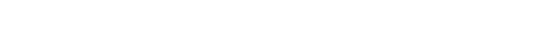
hindsii, Chlamys........... 110,114-115, 120, pl. 14 incerta, Astarte .

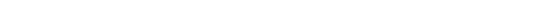
intermedia, Mya _..._................... 118 Introduction islandicus, Chlamys japonica, Mya arenaria.................... 118 Terebratulina........................ 107 kagamianus, Pecten kroyeri, Plicifusus..................... 110, 114, pl. 13 kurriana, Cyrtodaria............. 107,110, 119, pl. 14 
L Page

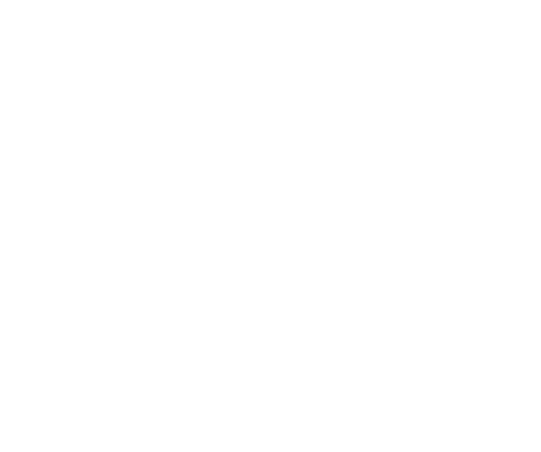

M

Macoma calcarea $106,110,117-118$, pls. 12, 14, 15, 17

Mactra polynyma alaskana.............. 118 major, Tachyrhynchus erosus.......... 109, 110, pl. 13 Martesia cuneiformis................. 107 striata L $_{-} \ldots \ldots$ sp martini, Astarte .................... 102, 105, pl. 12 marylandica, Emarginula ................. 101-102 Megafossils, of Gubik formation............. 108-120 of Nuwok formation .................. 100-108 mesleri, Neptunea ventricosa.............. 112, pl. 17 minuta, Nuculana . ........................ 104 montagui vernicosa, Astarte.................... 116 morrisi, Nuculana ................ 102, 104, 120, pl. 10 multistriata, Neptunea fornicata............. 111 Mya arenaria arenaria japonica intermedia truncata

Mytilus californianus ..................... 104

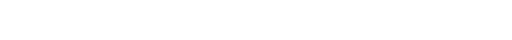

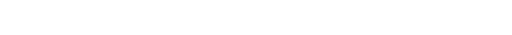

$\mathrm{N}$

Natica affinis. aleutica_-_._. clausa consors.

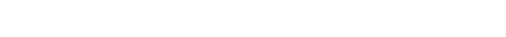
(Cryptonatica) clausa............. 109, pls. 13, 15

Neptunea andersoni ..................... pl. 17 arthritica $\begin{array}{lll}\text { decemcostata..................................... } & 113\end{array}$ despecta decemcostata pumilia elatior fornicata multistriata................. 111 leffingwelli _..... 108,110-111,113,120, pl. 13 faunule

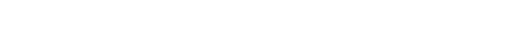
pribiloffensis _................... 112-113, pl. 17

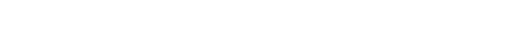
rentricosa _..._._._. 110,111,112 113, pl. 17 beringianus.......... 110, 111,118 11s, pl. 17 clarki faunule communis_.................. 110,111, pl. 14 faunule fornicata mesleri_.................. 112, pl. 17 soluta $\ldots \ldots \ldots \ldots$......... 110,112, pls. 15, 16, 17 faunule

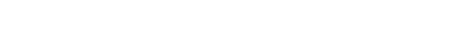
New species, descriptions................... 120121 noblis, Scaphander ........................... 103 nomensts, Cardita (Cyclocardia) crebicostata. .-- 117 normale, Buccinum _........ 114

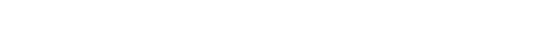

Page
Nuculana leonina

minuta morrisi_.......... 102,104,120, pl. 11

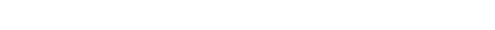
washingtonensis_................. 104, 120

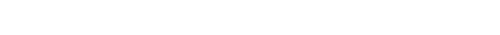
Nuwok formation, megafossils of.......... 100-108 origin of the name nuwokensis, Cardita (Cyclocarcia) _.... 102, 105, pl. 12 Chlamys_......... 102, 104, 108, 120-121, pl. 11 nystiana, Emarginula_................. 101-102, 103 o, $\mathbf{P}$

ochotense, Buccinum............... 110, 113, pl. 13 orbellus, Taras............................. 106 ovata, Arctica pallida, Lunatia Palliolum groenlandicum _............ 102, 104, $\mathrm{pl} .11$ patula, Siliqua Pecten kagamianus........................ 121 peculiaris, Terebratulina..................... 107 Pelecypoda of Gubik formation of Nuwok formation ................. 103-107

Periploma abyssorum fragilis_............. 102, 106, pl. 11 pernula, Nuculana perversa, Antiplanes................. 110, 114, pl. 13 pholadis, Saxicava physematum, Buccinum .......... 110, 113, pl. 13 piltunensis, Fortipecten plectrum, Buccinum............... 110, 113, p1. 14 Plicifusus kroyeri_................ 110,114, pl. 13 polaris, Astarte....................... 105

polynyma, Spisula alaskana, Moctra Spisula voyi, Spisula pribilnffensis, Neptunea ............. 112-113, pl. 17 pubescens, Colus_............ 114 pumilia, Neptunea despecta................ 111 punctostriatus, Scaphander 103 purpurea, Antiplanes._.................. 101 Pyrulofusus deformis....... 113 harpa schraderi_........... 108, 110, 111, 113, pl. 13

\section{$\mathrm{R}, \mathrm{s}$}

regina, Admete $\ldots 101$ retusa, Terebratulina rostratus alaskensis, Balanus..... 110, 120, pls. 14, 17 russa, Natıca............................ 109 Sagavanirktok formation................. 100 sarsii, Thyasira Saxicava arctica .......... 100, 110, 119, pls. 14, 15 pholadis................... 110,119, pls. 15, 17 sayanus, Chlamys_...................... 104, 121 Scaphander alasken is........................ 103 conradi.................................... 103 lignarius_._._._._._._._. 102, 108, pl. 11 nobilis punctostriatus. washingtonensis..................... 103 watsoni

Scaphopoda, of Nuwok formation . .......... 107 schraderi, Pyrulofusus _.. _ 108, 110, 111, 113, pl. 13 semisulcata withami, Astarte_................ 116 septentrionalis, Terebratulina sericea, Astatte Sorealis_................... 116 Serripes groenlandicus _... 100, 110, 117 , pls. 14, 16, 17 sp_... (Serripes) hamiltonensis, Cardium _......... 117

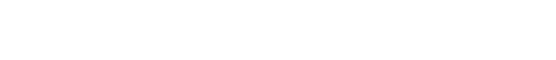
skullcliffensis, Lora $\ldots$ soluta, Neptunea Neptunea ventricosa...... 110, 112, pls. 15, 16, 17 solutus cordatus, Chrysodomus............. 111
Spisula grayana polynyma polynyma alaskana voui................. 110, 118-119, pl.14

spitsbergensis, Colus (Aulacofusis) _.. 110, 114, pl. 13 stefanssoni, Volutopsius_........... 110, pls. 14, 15 stimpsoni, Colus. ...................... 114 striata, Martesia............................ 107 subcrassidens, Cardita (Cyclocardia) _ 1117 Subemarginula) vadososinuata, Emarginula yatesii, Emarginula subequilatera, Astarte - - 110, 115, pl. 16 subtenta, Cardita sulcata, Astarte.......................... 105 surugaensis, Terebratulina (Surugathyris)_...... 107 (Surugathyris) surugaenis, Terebratulina__.... 107 $\mathbf{T}$

Tachyrhynchus erosus erosus major takahashii, Fortipecten $\ldots . . . . . . . . . . . . .104$

Taras orbellus

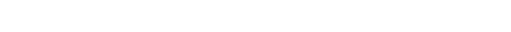
sp

Tellina

tenuae, Buccinum

Terebratula grandis....................... 108 vancouverensis_..................... 108 sp......................... 102, 108, pl. 11 Terebratulina caput-serpentis_............. 107 japonica ............................. 107 peculiaris_........................... 107 retusa _.................. 102, 107-108, pl. 11 septentrionalis (Surugathyris) surugaenis..._.......... 107 unguicula _

Thracia truncata ................. 102, 106, pl. 11 truncata devexa

Thyasira arctica $\ldots . . . . . . . . . .102,10 f$, pl. 12 bisecta_............................... 106 disjuncta flexuosa gouldii _.... sarsii _.. _.......................... 106 torrelli, Taras ................. 106

truncata, Mya Thracia ................. 102, 106, pl. 11 devexa, Thracia U-Y

unguicula, Terebratulina_................... 107 vadososinuata, Emarginula (Subemarginula). 101, 103 vancouverensis, Terel ratula.................... 108 variciferous, Neptunea ventricosa............... 112 ventricosa beringianus, Neptunea.............. 112 clarki, Neptunea ................ 110, 111, pl. 16 communis, Neptunea fornicata, Neptunea. mesleri, Neptunea Neptunea -........... 110.111,112-119, pl. 17 soluta, Neptunea ......... 110,112, pls. 15, 16, 17 pariciferous, Neptunea vernicosa, Astarte ............. 105, 110. 116, pls. 15, 17 Astarte montagui.................... 116 virginianus, Chlamys

Volsella

Volutopsius beringi.................... 110-111 stefanssoni..................... 110, pls. 14, 15 voyi, Spisula polynyma washingtonensis, Nuculana.................. 104, 120

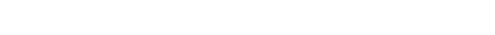
watsoni, Scaphander... Ami, Astarte borealis Astarte semisulcata...................... 116 Worm tubes, unidentifled, in Gubik formation - 110,120 unidentified, in Nuwok formation...... 102, 108 Xylophaga dorsalis.......................... 107 yatesii, Emarginula (Subemarginula) _......... 101. $102,103, \mathrm{pl} .11$

Yoldia limatula .................... 109 


\section{PLATES 11-17}




\section{PLATE 11}

FrguRe 1. Emarginula (Subemargiula) sp. aff. E. (S). yatesii Dall (p. 101).

Figured specimen, USNM 561863, $\times 1 \frac{11}{2}$; length, $24.5 \mathrm{~mm}$; height $11+\mathrm{mm}$. Locality, USGS D50 (T).

2, 10. Scaphander aff. S. lignarius (Linné) (p. 103).

Figured specimen, USNM 561864, $\times 1 \frac{11}{2}$; height, $41 \mathrm{~mm}$; diameter, $19 \mathrm{~mm}$. Locality, USGS D50 (T).

3. Nuculana morrisi MacNeil, n. sp. (p. 104, 120).

Holotype, USNM 561865, × 2; length, $16.8 \mathrm{~mm}$; height, $7.6 \mathrm{~mm}$. Locality, USGS D50 (T).

4-6, 12. Chlamys nuwokensis MacNeil, n. sp. (p. 104, 120-121).

4. Holotype, USNM 561866, $\times 1 \frac{1}{2}$, left valve; width, $60 \mathrm{~mm}$.

5, 6. Paratypes, USNM 561867 and $561868, \times 2$, left valves.

12. Paratype, USNM $561869, \times 2$, right valve.

Locality, USGS D50 (T).

7, 8. Astarte sp. (p. 105).

Figured specimens, USNM 561870 and $561871, \times 1 \frac{11}{2}$; greatest dimension of fragment in figure 7, $29 \mathrm{~mm}$. Locality USGS D50 (T).

9, 11, 15. Thracia sp. aff. T. iruncata Brown (=myopsis Möller) (p. 106).

Figured specimen, USNM 561872, ×2; length, $24.5 \mathrm{~mm}$; height, $18.5 \mathrm{~mm}$. Locality, USGS D50 (T).

13. Astarte sp. aff. A. laurentiana Lyell (p. 105).

Figured specimen, USNM 561873, $\times 2$; length, $17.8 \mathrm{~mm}$; height, $14.2 \mathrm{~mm}$. Locality, USGS D50 (T).

14, 20. Periploma sp. aff. P. fragilis Totten (p. 106 ).

Figured specimen, USNM 561874, $\times 2$; length, $23.5 \mathrm{~mm}$; height, $18+\mathrm{mm}$. Locality, USGS D50 (T).

16. Terebratulina sp. aff. T. retusa (Linné) (=caput-serpentis Linné auctores) (p. 107-108).

Figured specimen, USNM 561875, $\times 2$; length, $20.5 \mathrm{~mm}$; width, $14 \mathrm{~mm}$. Locality, USGS D50 (T).

17, 18. Palliolum groenlandicum (Sowerby) (p. 104).

Figured specimens, USNM 561876 and $561877, \times 4$; width, $8 \mathrm{~mm}$; height, $7.8 \mathrm{~mm}$. Locality, USGS D50 (T).

19. 23. "Terebratula" sp. (p. 108).

Figured specimens, USNM 561878 and $561879, \times 2$.

19. Height, $22 \mathrm{~mm}$.

23. Greatest width of fragment, $22.5 \mathrm{~mm}$.

Locality, USGS D50 (T).

21-22. ?Cyrtodaria sp. (p. 107).

Figured specimen, USNM 561880, $\times$ 11/2, an internal mold; length, 29 mm; height, $11 \mathrm{~mm}$. Locality, USGS D50 (T).

24. ?Taras sp. (p. 106).

Figured specimen, USNM 561881, a terminal view with the beak broken off, $\times 2$; greatest dimension of the valve on the right, $9 \mathrm{~mm}$. Locality, USGS D50 (T). 

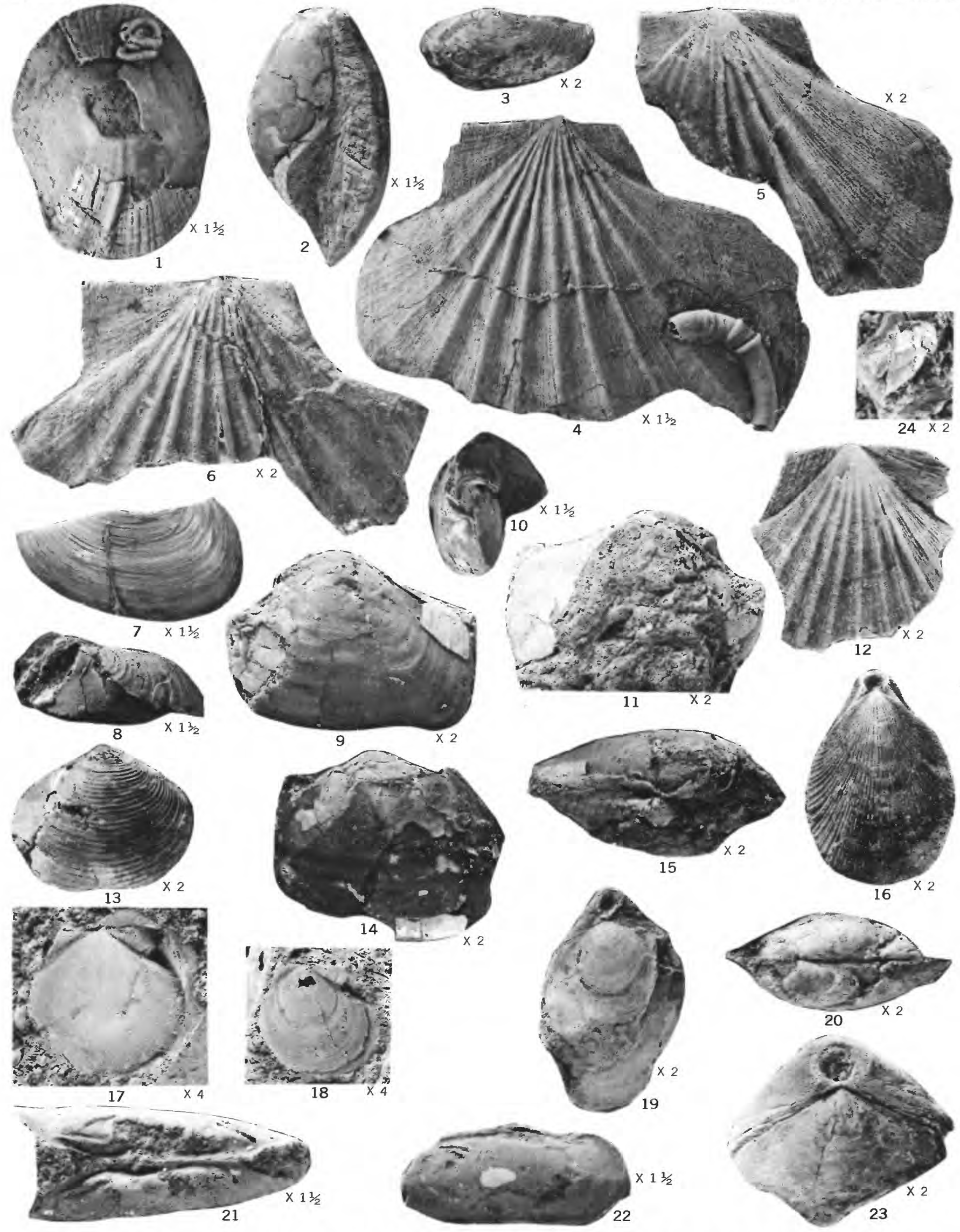

FOSSILS OF THE NUWOK FORMATION OF DALL, CHLAMYS NUWOKENSIS ZONE, AT CARTER CREEK 

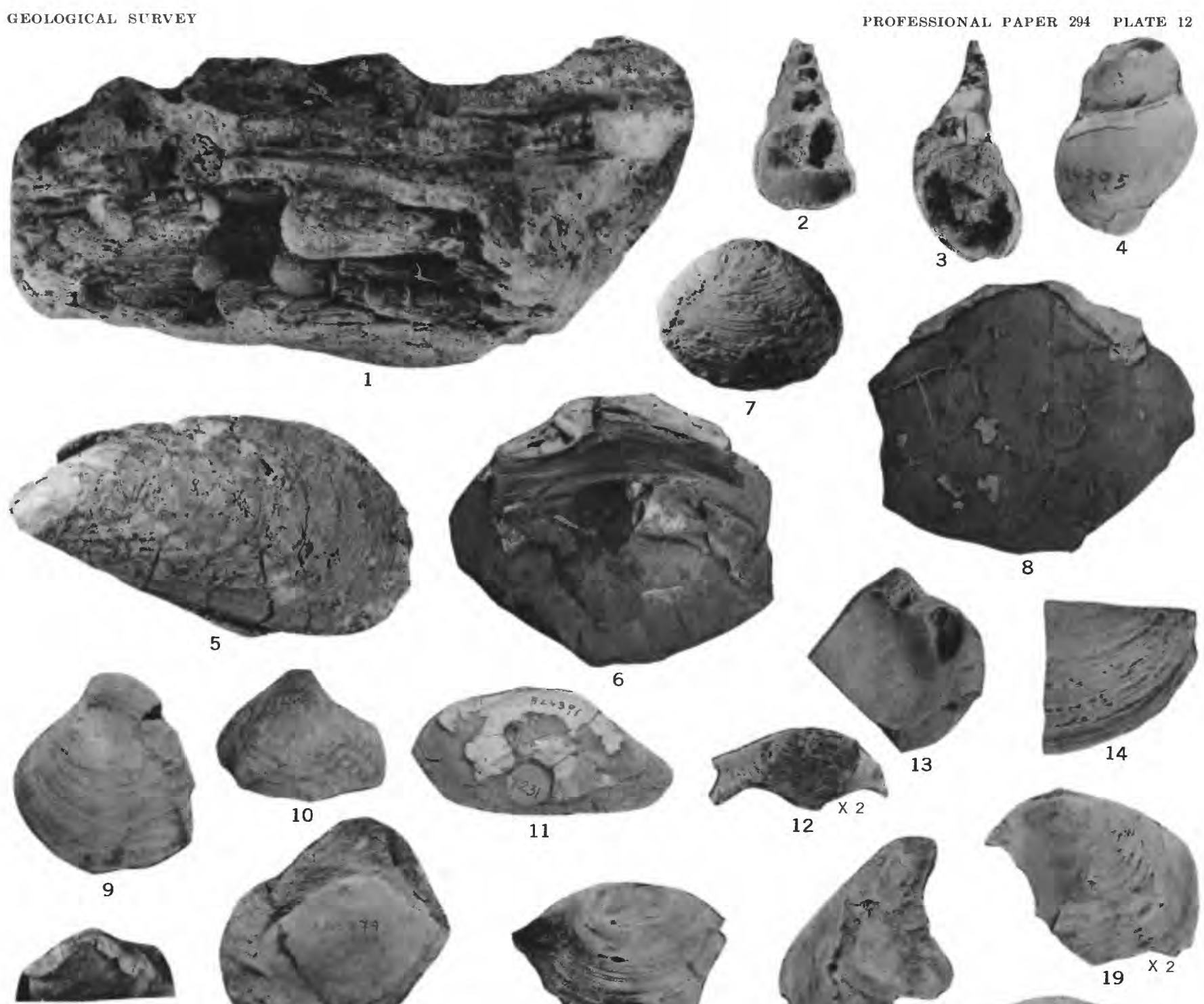

15

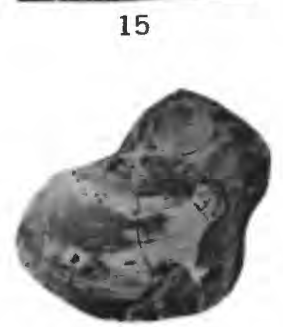

20
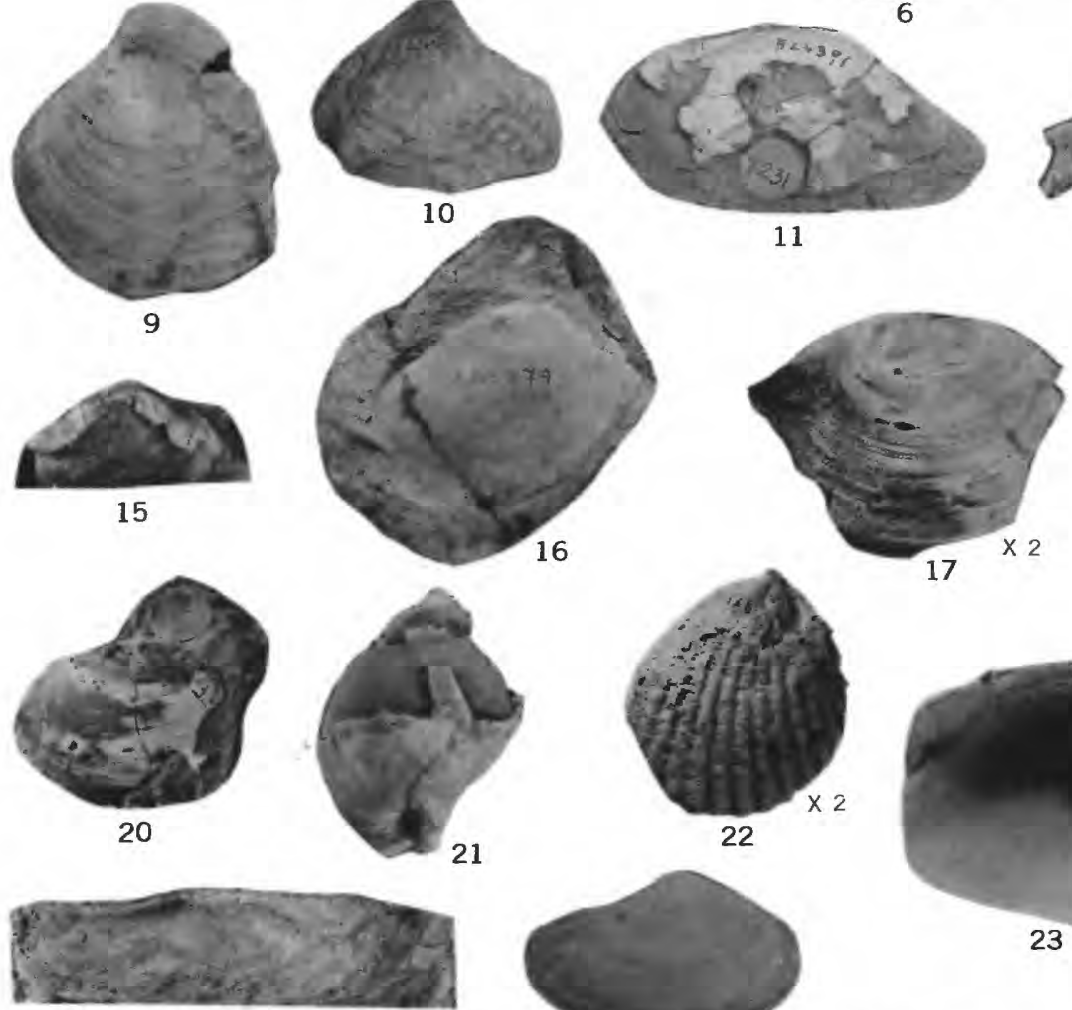

25
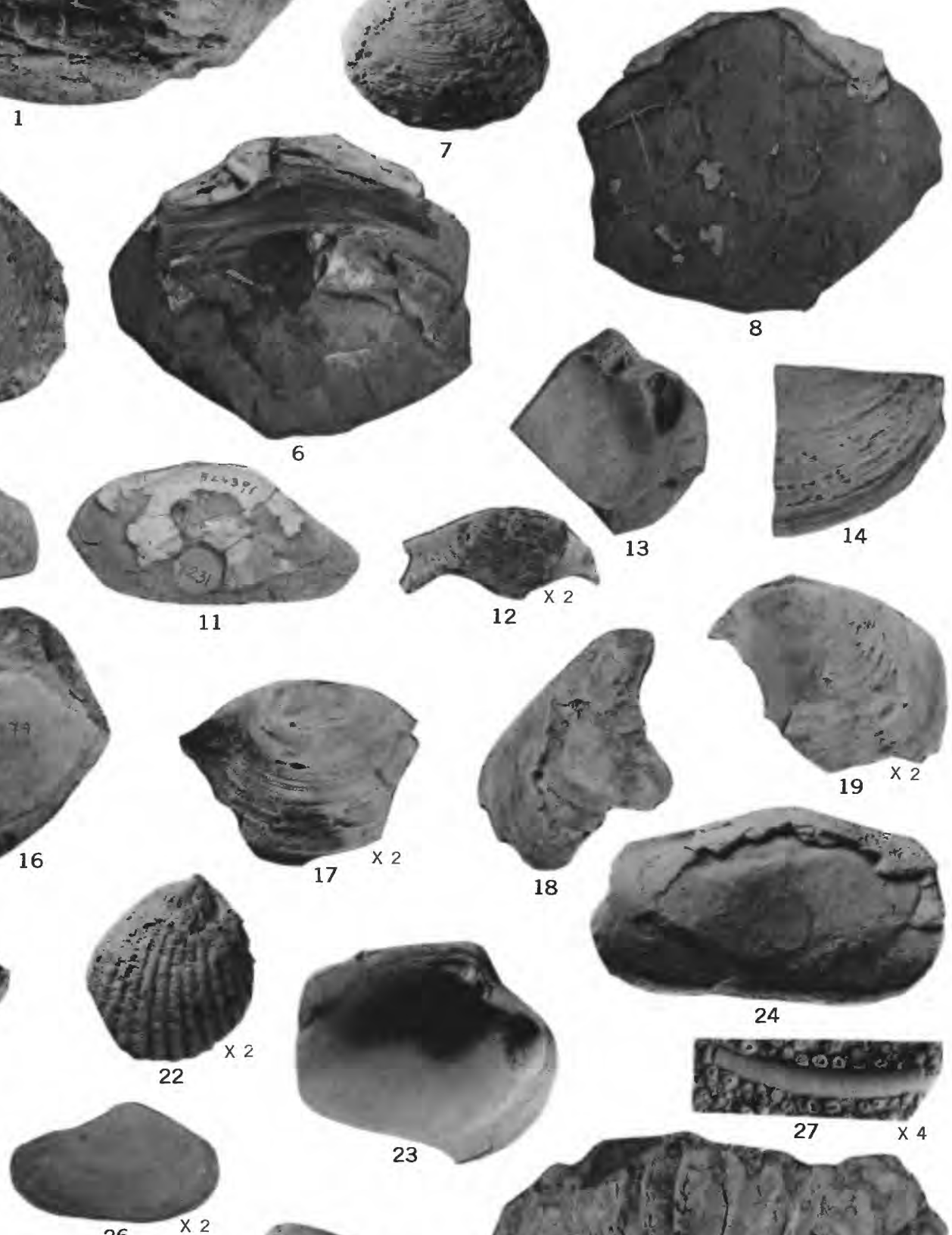

8 


\section{PLATE 12}

FIGURE 1. ?Martesia sp. (p. 107).

[All figures natural size except as indicated]

Figured specimen, USNM 561882, several individuals in carbonized wood; diameter of larger individual in center, $11.5 \mathrm{~mm}$. Locality, USGS D49 (T).

2, 3. ? Anomalosipho sp. (p. 103).

Figured specimens, USNM 561883 and 561884. Locality, USGS Tert. loc. 7068a.

4. ?Colus sp. (p. 103).

Figured specimen, USNM, 561885. Locaiity, USGS Tert. loc. 7231.

5. ?Mytilus sp. (p. 104).

Figured specimen, USNM 561886; length, $62 \mathrm{~mm}$. Locality, USGS D498 (T).

$6,8,13,14$,

23, 30. Arctica carteriana (Dall) (p. 105).

6, 8. Figured specimen, USNM 324394; length, $55 \pm \mathrm{mm}$; height, $51 \pm \mathrm{mm}$. Locality, USGS Tert. loc. 7231.

13. Figured specimen, USNM 561887. Locality, USGS Tert. loc. 7068a.

14. USNM 324389; fragment showing external sculpture. Locality, USGS Tert. loc. 7231.

23, 30. Holotype of Astarte carteriana Dall, USNM 324304; length of fragment, $36 \mathrm{~mm}$. Locality, USGS Tert. loc. 7069 .

7. Astarte martini Dall (p. 105).

Holotype, USNM 324307 ; length, $27.5 \mathrm{~mm}$. Locality, USGS Tert. loc. 7231.

9, 10. Thyasira sp. aff. T. arctica Soot-Ryen (p. 106).

Figured specimen, USNM 561888, both valves of one individual; height of left valve, $32 \mathrm{~mm}$. Locality, USGS D52 (T)

11. Macoma sp. cf. M. calcarea (Gmelin) (p. 106).

Figured specimen, USNM 324391; length, $41 \mathrm{~mm}$. Locality, USGS Tert. loc. 7231.

12, 17-19. Astarte sp. (p. 105).

Figured specimens, USNM 561889, $\times 2$. Locality, USGS Tert. loc. 7230.

15, 20. Astarte sp. (p. 105).

Figured specimens, USNM 561890. Locality, USGS Tert. loc. 7070.

16. ?Nucula sp. (p. 103-104).

Figured specimen, USNM 324379. Locality, USGS Tert. loc. 7068b.

21. Lunatia sp. aff. L. groenlandica (Möller) (p. 103).

Figured specimen, USNM 561891. Locality, USGS Tert. loc. 7070.

22. Cardita (Cyclocardia) nuwokensis (Dall) (p. 105).

Holotype, USNM 324310, × 2; height, $13 \mathrm{~mm}$. Locality, USGS Tert. loc. 7230.

24, 25, 28. Cyrtodaria camdenensis Dall (p. 107).

24. Holotype, USNM 324311; length, $47 \mathrm{~mm}$. Locality, USGS Tert. loc. 7070.

25. Figured specimen, USNM 561892, hinge of a left valve. Locality, USGS Tert. loc. 7068a.

28. Topotype, USNM 561893. Locality, USGS Tert. loc. 7070.

26. ?Nuculana sp. (p. 104).

Figured specimen, USNM 561894, $\times 2$. Locality, USGS Tert. loc. 7070.

27. ?Cadulus arcticus Dall (p. 107).

Holotype, USNM 324322, X 4; length, $7.5 \mathrm{~mm}$. Locality, USGS Tert. loc. 7070.

29. Balanus crenatus (Bruguière) (p. 108).

Figured specimen, USNM 561895. Locality, USGS Tert. loc. 7068a.

31. Balanus balanoides (Linné) (p. 108).

Figured specimen, USNM 324396. Locality, USGS Tert. loc. 7231. 


\section{PLA'TE 13}

[Figures natural size unless otherwise indicated]

Figures 1-4, 9. Neptunea leffingwelli (Dall) (p. 111).

1, 4. Figured specimen, USNM 561896, a mature individual; height, $93+\mathrm{mm}$; diameter, $57 \mathrm{~mm}$. Locality, USGS D306 (T).

3, 9. Figured specimens, USNM 561897 and 561898. Locality, USGS D306 (T).

2. Figured specimen showing finer secondary lirae, USNM 561899. Locality, USGS D305 (T).

5-6. Astarte broweri Meek (p. 115-116).

Figured specimen, USNM 561900; height, $29.5 \mathrm{~mm}$; length, $38 \mathrm{~mm}$. Locality, USGS D306 (T).

7. Neptunea sp. cf. N. elatior (Middendorff) (p. 110-111).

Figured specimen, USNM 561901; diameter, $37 \mathrm{~mm}$; height (incomplete), $52 \mathrm{~mm}$. Locality, USGS D305 (T).

8, 18. Buccinum sp. aff. B. ochotense (Middendorff) (p. 113).

Figured specimen, USNM 561902; height, $38 \mathrm{~mm}$; diameter, $22.4 \mathrm{~mm}$. Locality, USGS D306 (T).

10. Buccinum physematum Dall (p. 113).

Figured specimen, USNM 561903, $\times 2$; height, $15.5 \mathrm{~mm}$; diameter, $9 \mathrm{~mm}$. Locality, USGS D306 (T).

11. Antiplanes ef. A. perversa (Gabb) (p. 114).

Figured specimen, USN M 561904, × 11/2; diameter, $14.7 \mathrm{~mm}$. Locality, USGS D306 (T).

12, 13. Natica (Cryptonatica) clausa Broderip and Sowerby (p. 109).

Figured specimens, USNM 561905, $\times 1 \frac{112}{2}$ and 561906, $\times 1 ; 13 . \quad$ Height, $26.6 \mathrm{~mm}$; diameter, $27 \mathrm{~mm}$. Locality, USGS D306 (T).

14. Plicifusus aff. P. kroyeri (Möller) (p. 114).

Figured specimen, USNM 561907, $\times 1 \frac{1}{1}$; height, $31.5 \mathrm{~mm}$; diameter, $13 \mathrm{~mm}$. Locality, USGS D306 (T).

15. Colus (Aulacofusus) spitsbergensis (Reeve) (p. 114).

Figured specimen, USNM 561908; height, $40 \mathrm{~mm}$. Locality, USGS D306 (T).

16, 17. Tachyrhynchus erosus major Dall (p. 109).

16. Figured specimen, USNM 561909, $\times 2$; height, $18 \mathrm{~mm}$; diameter, $6.5 \mathrm{~mm}$. Locality, USGS D305 (T).

17. Figured specimen, USNM 561910; height, $36 \mathrm{~mm}$. Locality, USGS D306 (T).

19, 20. Cardita (Cyclocardia) ef. crebricostata (Krause) (p. 117).

Figured specimen, USNM 561911, $\times 1 \frac{1}{1}$; length, $23.7 \mathrm{~mm}$; height, $20.4 \mathrm{~mm}$. Locality, USGS D306 (T).

21. Pyrulofusus schraderi Dall (p. 113).

Holotype, USNM 210854; diameter, $59 \mathrm{~mm} \quad$ Locality, USGS Tert. loc. 627. 

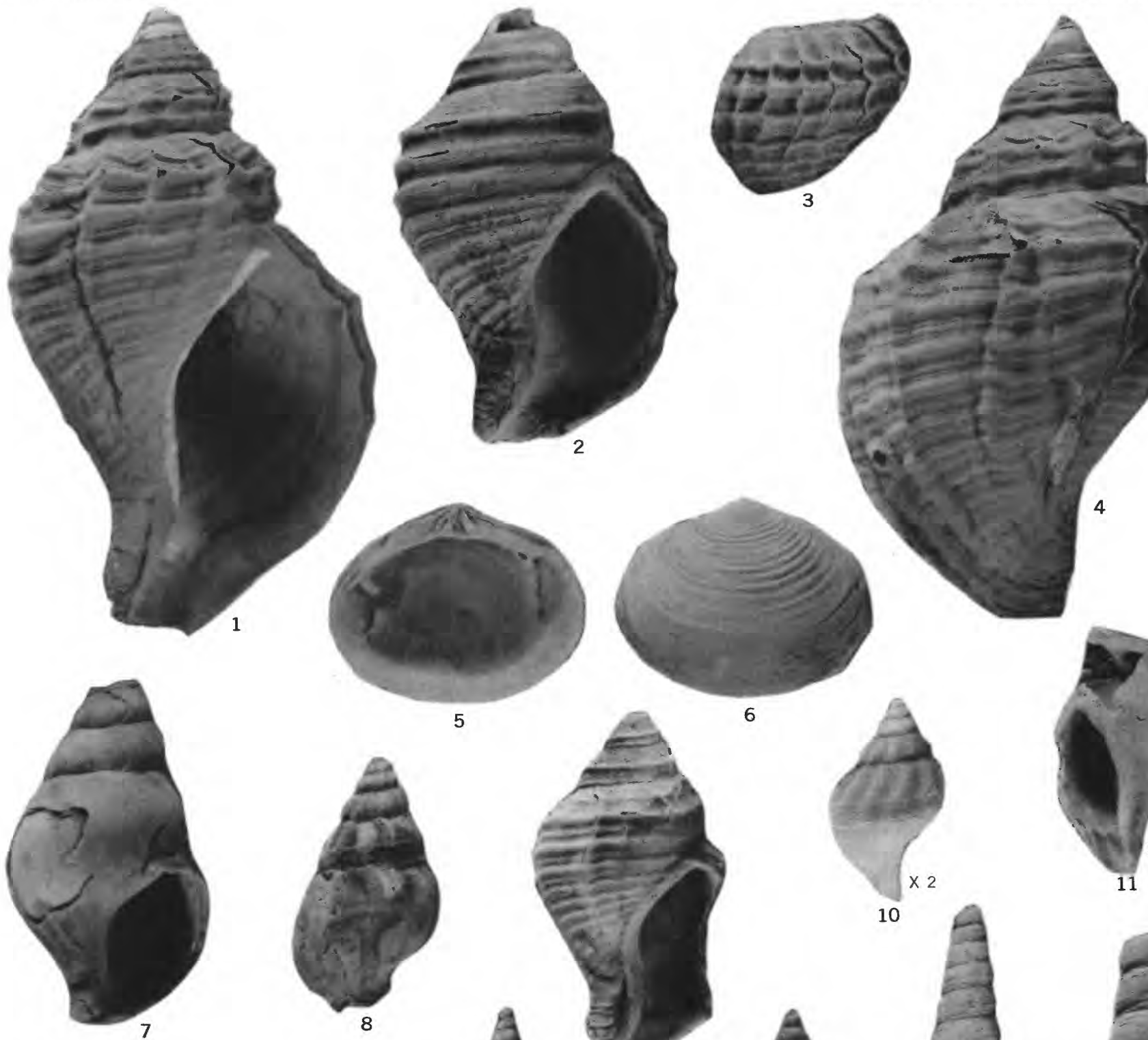

5
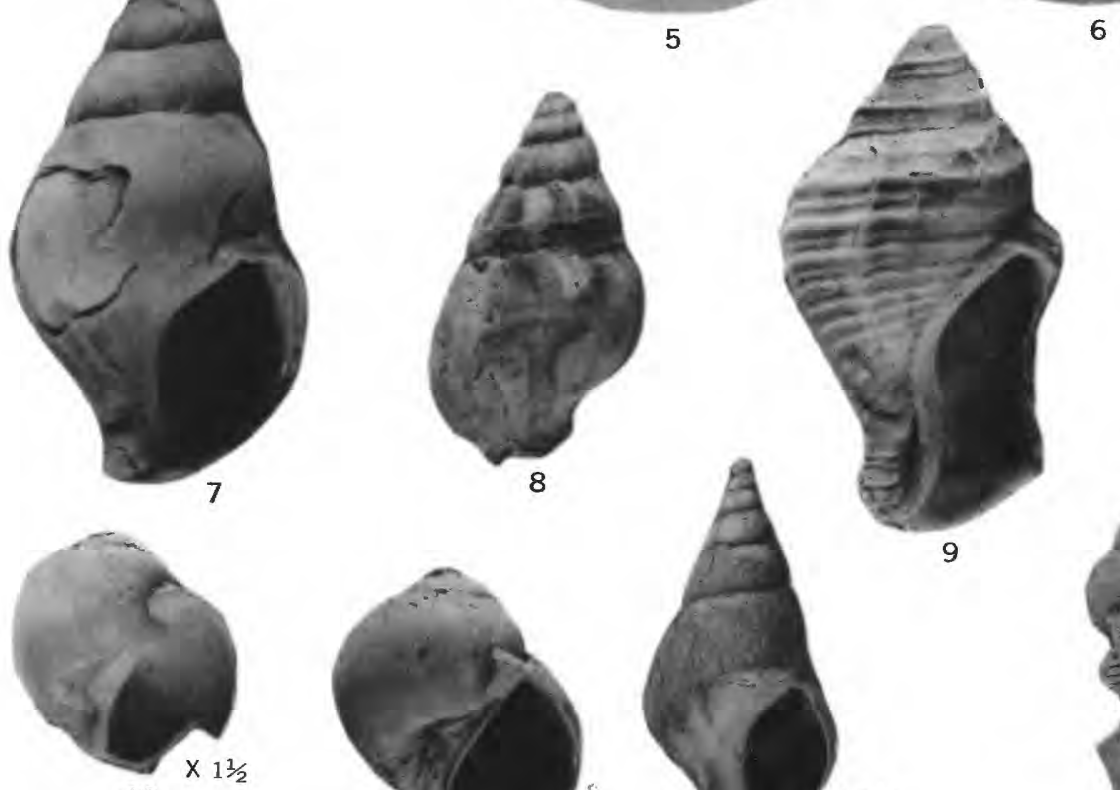

12
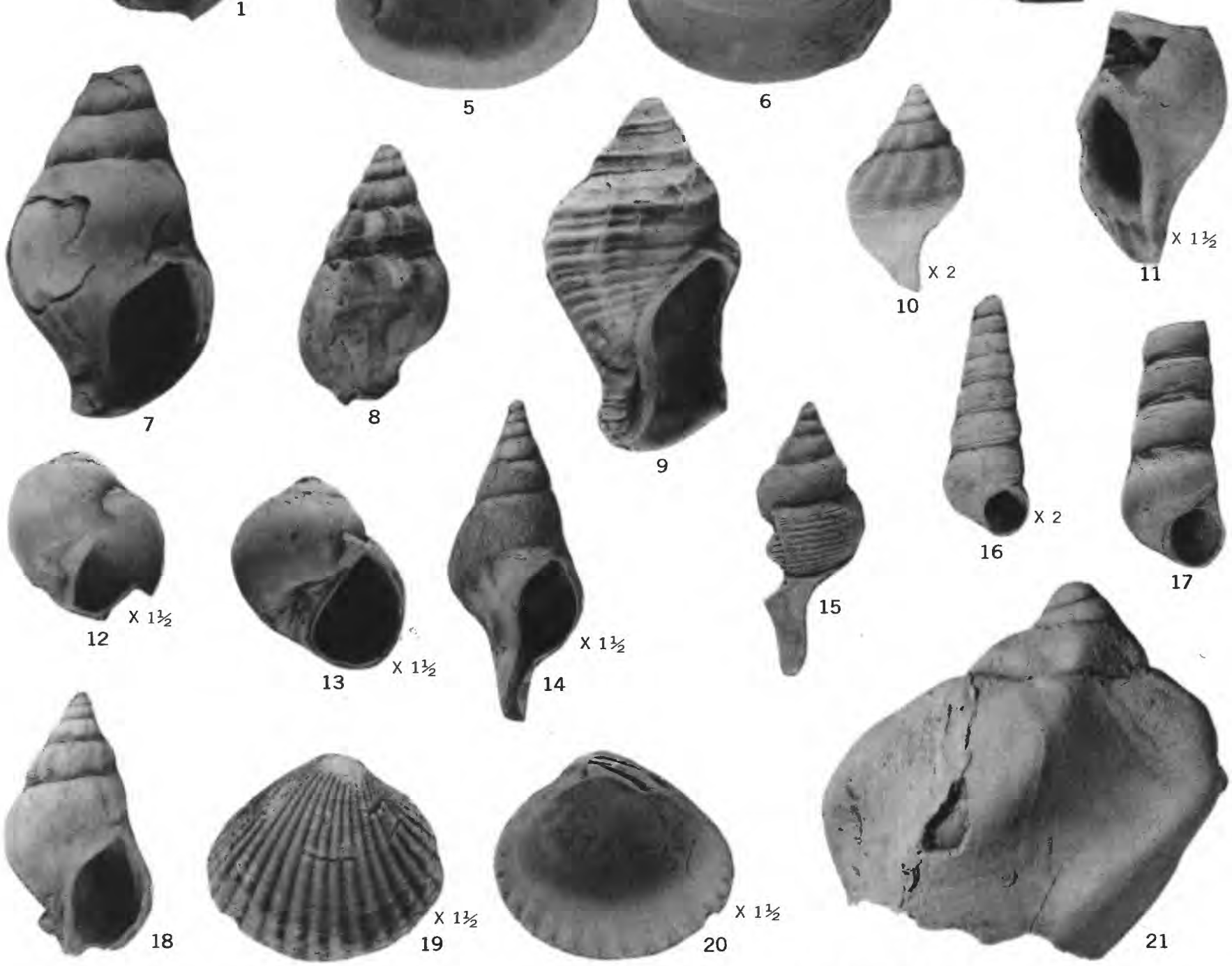

(1)
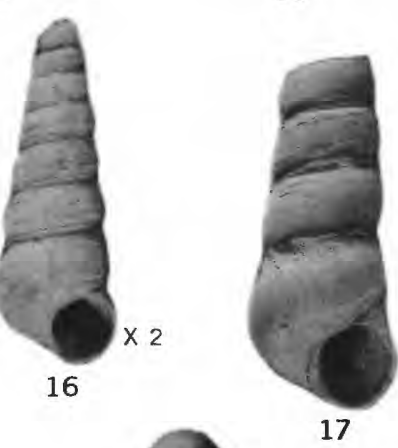

FOSSILS OF THE GUBIK FORMATION, NEPTUNEA LEFFINGWELLI FAUNULE, COLVILLE RIVER 


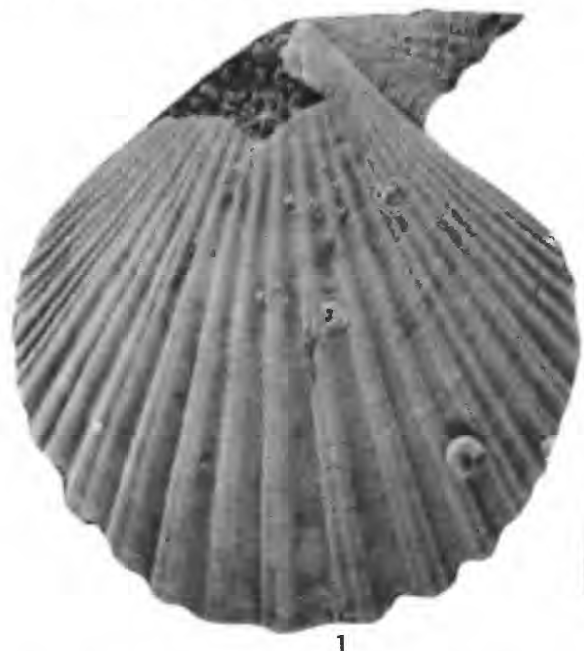

1
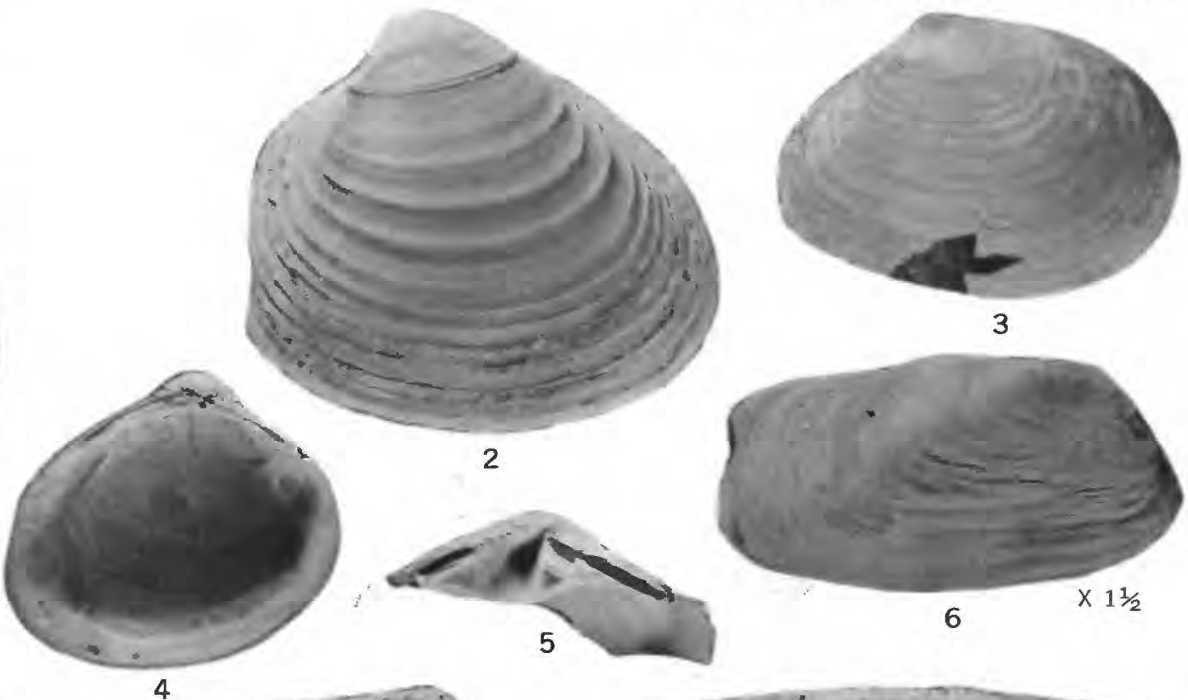

3
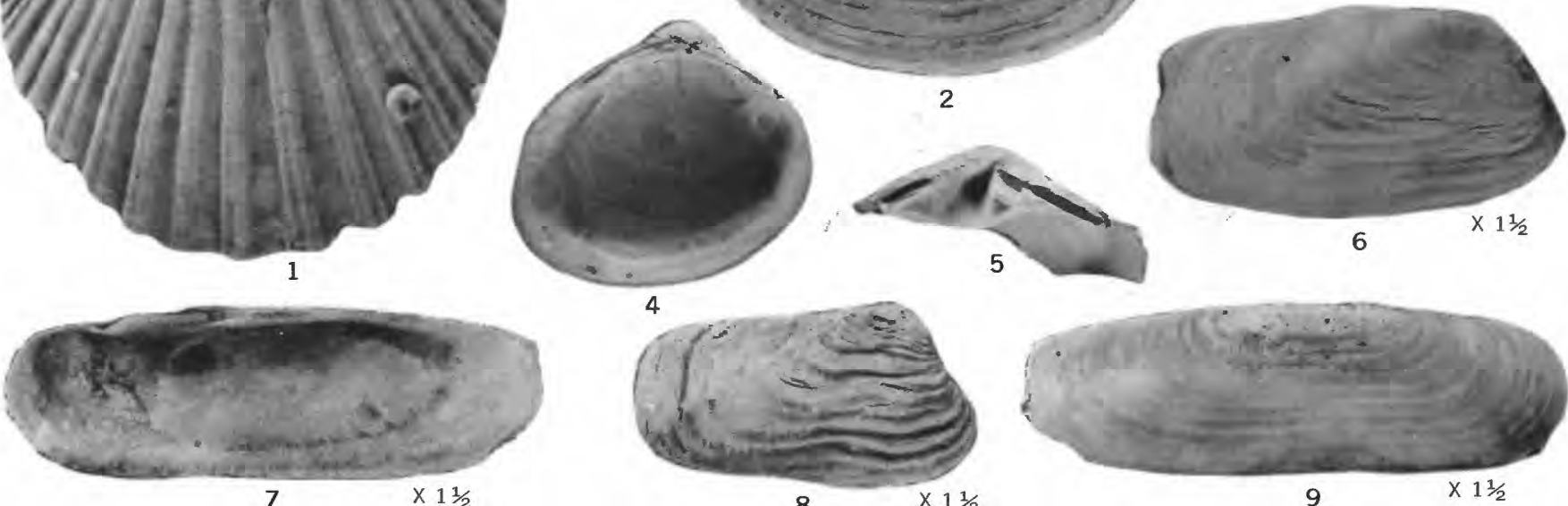

8

$\times 1 \frac{1}{2}$
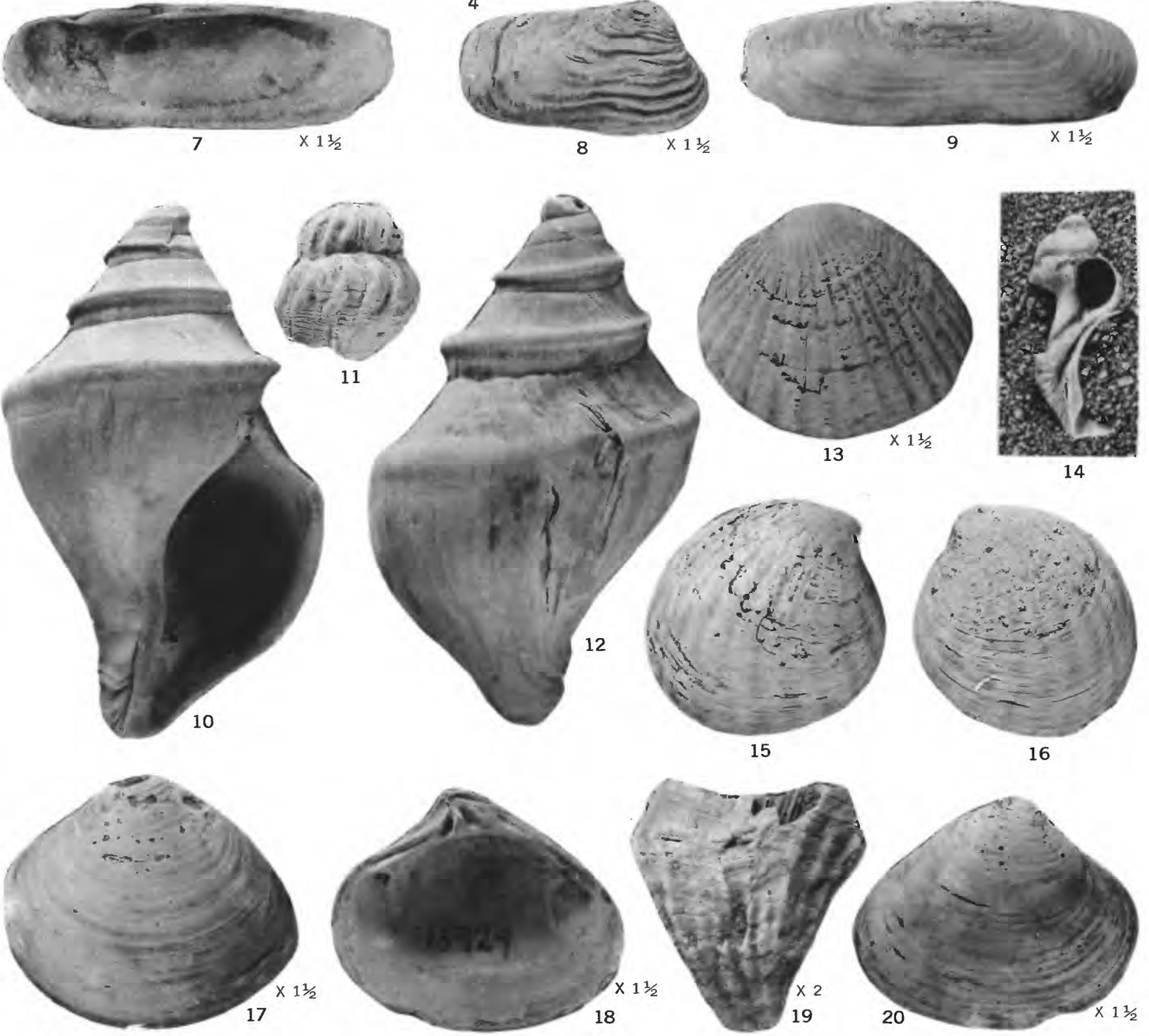

FOSSILS OF THE GUBIK FORMATION, NEPTUNEA LEFFINGWELLI FAUNULE, COLVILLE RIVER, AND NEPTUNEA VENTRICOSA COMMUNIS FAUNULE, MEADE RIVER 


\section{PLATE 14}

[Figures natural size unless otherwise indicated]

Figure 1. Chlamys hindsii (Carpenter) (p. 114-115).

Figured specimen, USNM 561912; width, $58 \mathrm{~mm}$; height, $62 \mathrm{~mm}$. Locality, USGS D306 (T).

2, 4. Serripes groenlandicus (Bruguière) (p. 117).

2. Figured specimen, USNM 561913; height, $42 \mathrm{~mm}$.

4. Figured specimen, USNM 561914; height, $29.6 \mathrm{~mm}$; length, $34.3 \mathrm{~mm}$. Locality, USGS D306 (T).

3. Macoma calcarea (Gmelin) (p. 117).

Figured specimen, USNM 561915; length, $41.9 \mathrm{~mm}$; height, $30 \mathrm{~mm}$. Locality, USGS D305 (T).

5. Spisula ef. S. polynyma voyi (Gabb) (p. 118-119).

Figured specimen, USNM 561916, $\times 1$; length of fragment, $32 \mathrm{~mm}$. Locality, USGS D306 (T). 6, 8. Saxicava arctica (Linné) (p. 119).

Figured specimens, USNM 561917 and 561918, $\times$ 11/2. 6. Length, $32.4 \mathrm{~mm}$. Locality, USGS D306 (T). 7, 9. Cyrtodaria kurriana (Dunker) (p. 119).

Figured specimen, USNM 561919, × 11/2; length, $42 \mathrm{~mm}$; height, $13 \mathrm{~mm}$. Locality, USGS D306 (T).

10, 12. Neptunea ventricosa communis (Middendorff) (p. 111).

Figured specimen, USNM 561920, height, $84.5 \mathrm{~mm}$; diameter, $52.5 \mathrm{~mm}$. Locality, USGS Tert. loc. 15929.

11. Buccinum plectrum Stimpson (p. 113).

Figured specimen, USNM 561921; diameter, $23 \mathrm{~mm}$. Locality, USGS Tert. loc. 15929.

13. Cardita (Cyclocardia) cf. crebricostata (Krause) (p. 117).

Figured specimen, USNM 561922, X 11/2; length, $29.6 \mathrm{~mm}$; height, $25.6 \mathrm{~mm}$. Locality, USGS Tert. loc. 15929.

14. Volutopsius sp. aff. V. stefanssoni Dall (p. 110).

Figured fragment, USNM 561923; height, $36.6 \mathrm{~mm}$. Locality, USGS Tert. loc. 15929.

15, 16. Cardita (Cyclocardia) crassidens (Broderip and Sowerby) (p. 117).

15. Figured specimen, USNM 561924, a right valve; height, $35.8 \mathrm{~mm}$; length, $37.8 \mathrm{~mm}$.

16. Figured specimen, USNM 561925, a left valve. Locality, USGS Tert. loc. 15929.

17, 18, 20. Astarte leffingwelli Dall (p. 116).

17. Figured specimen, USNM 561926, $\times 1 \frac{1}{2}$, exterior of a left valve; height, $21.5 \mathrm{~mm}$; length, $32 \mathrm{~mm}$.

18, 20. Figured specimen, USNM 561927, $\times 1 \frac{1}{2}$, a right valve.

Locality, USGS Tert. loc. 15929.

19. Balanus rostratus alaskensis Pilsbry (p. 120).

Figured specimen, USNM 561928, × 2; height, $20 \mathrm{~mm}$; the figure is inverted. Locality, USGS Tert. loc. 15929. 


\section{PLATE 15}

[Figures natural size unless otherwise indicated]

Figures 1-6. Astarte aff. A. vernicosa Dall (p. 116).

1. Figured specimen, USNM 561929, right valve; length, $39.5 \mathrm{~mm}$.

2, 5. Figured specimen, USNM 561930, right valve.

$3,4,6$. Figured specimens, USN M 561931, 561932, and 561933, left valves.

Locality, USGS Tert. loc. 15929.

7, 8, 10, 11. Astarte bennetti Dall (p. 116).

7, 11. Figured specimens, USNM 561934, $\times 11 / 2$, right valve.

8, 10. Figured specimens, USNM 561935, $\times 1 \frac{1}{2}$, left valve; length, $23.4 \mathrm{~mm}$; height, $22.6 \mathrm{~mm}$.

Locality, USGS Tert. loc. 15929.

9. Macoma calcarea (Gmelin) p. 117).

Figured specimen, USNM 561936, $\times 1 \frac{1}{2}$; length, $30 \mathrm{~mm}$. Locality, USGS Tert. loc. 15929 .

12. Saxicava arctica (Linné) (p. 119).

Figured specimen, USNM 561937; length, $36.7 \mathrm{~mm}$. Locality, USGS Tert. loc. 15929.

$13,14,17,18$. Neptunea ventricosa soluta (Heermann) (p. 112).

13. USNM 561938, spire fragment.

14. USNM 561939 , body whorl fragment.

17. USNM 561940, fragment of large specimen.

18. USNM 561941, body whorl fragment having a flared varix (broken off) at the shoulder. Locality, USGS D2 (T).

15, 16. Buccinum angulosum Gray (p. 113-114).

Figured specimen, USN M 561942; height, $59.5 \mathrm{~mm}$; diameter, $33 \mathrm{~mm}$. Locality, USGS D2 (T).

19. Natica (Cryptonatica) clausa Broderip and Sowerby (p. 109).

Figured specimen, USN M 561943, × 13/2; height, $16.3 \mathrm{~mm}$. Locality, USGS D2 (T).

20. Saxicava pholadis (Linne) (p. 119).

Figured specimen, USN M 561944; length, $38 \mathrm{~mm}$; height, $18 \mathrm{~mm}$. Locality, USGS D2 (T).

21, 22. Volutopsius sp. aff. V. stefanssoni Dall (p. 110).

Figured fragments, same specimen, USNM 561945, X 1. 22. Height, $50 \mathrm{~mm}$. Locality, USGS D2 (T). 
GEOLOGICAL SURVEY

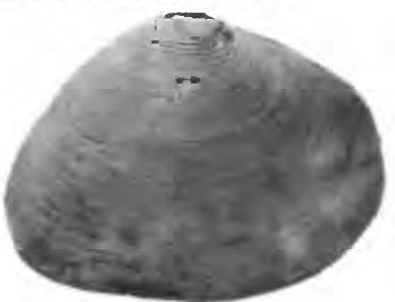

1

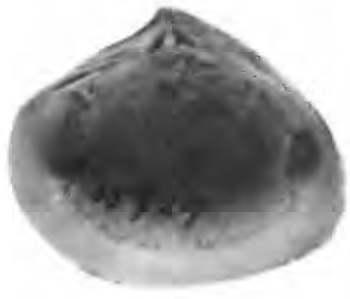

5
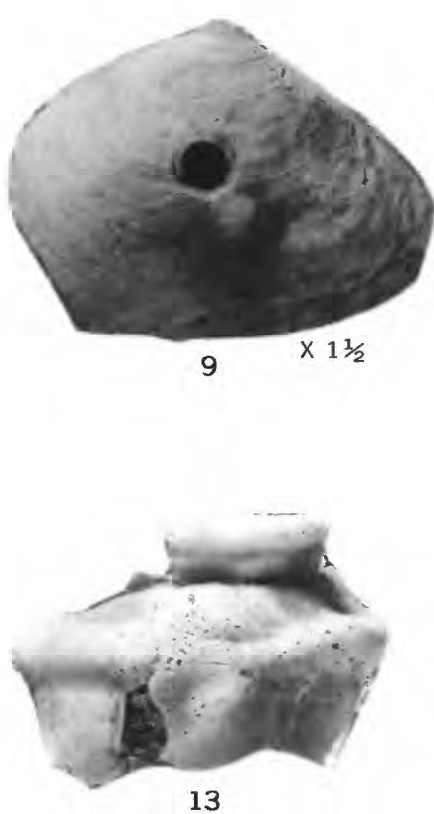

13

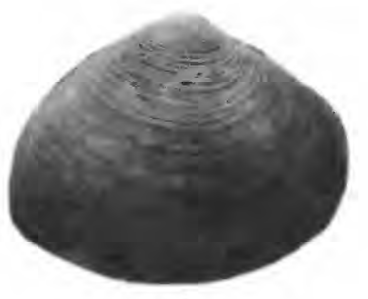

2
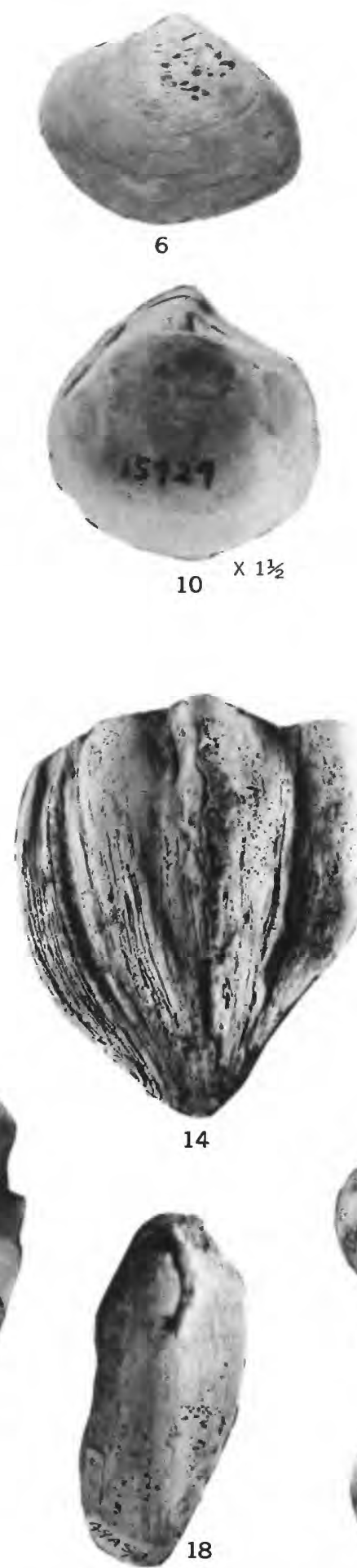

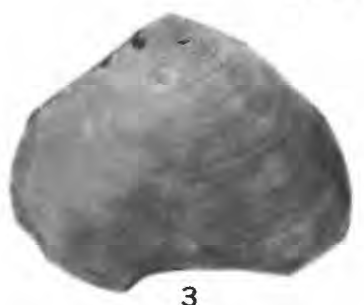

3
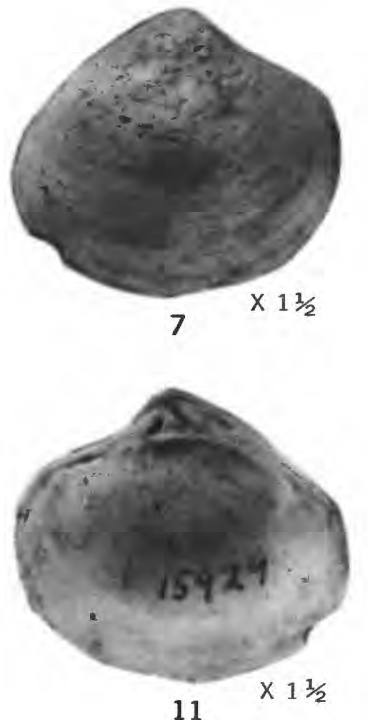

11
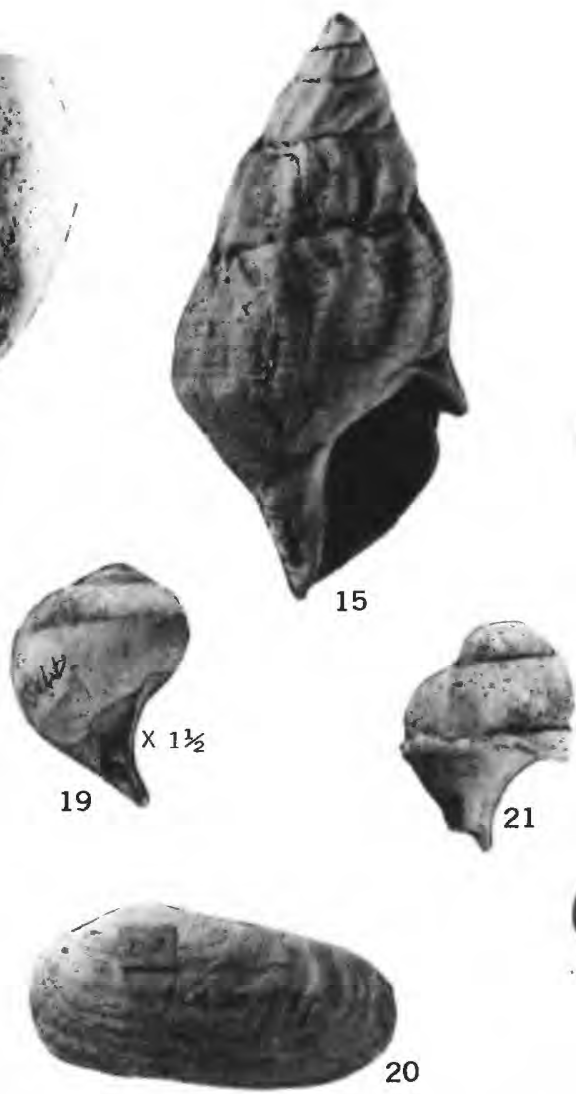
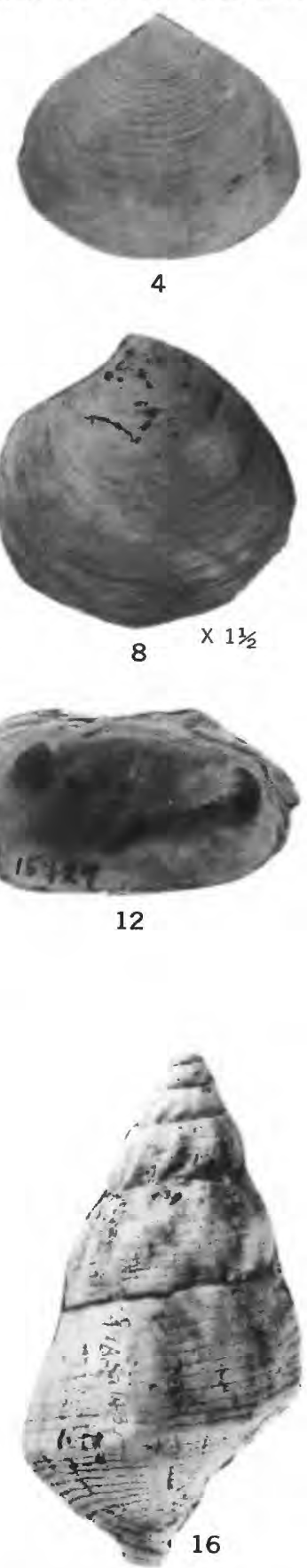

4
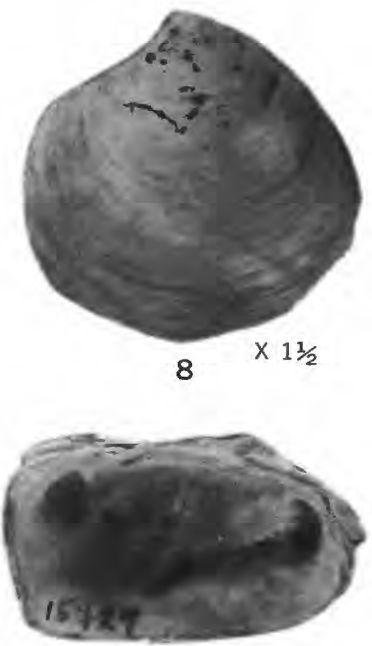

12

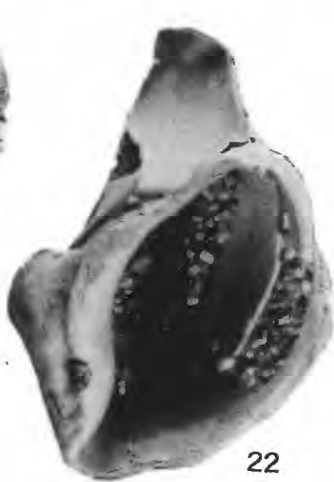

FOSSILS OF THE GUBIK FORMATION, NEPTUNEA VENTRICOSA COMMUNIS FAUNULE, MEADE RIVER, AND NEPTUNEA VENTRICOSA SOLUTA FAUNULE, KUKPOWRUK RIVER 

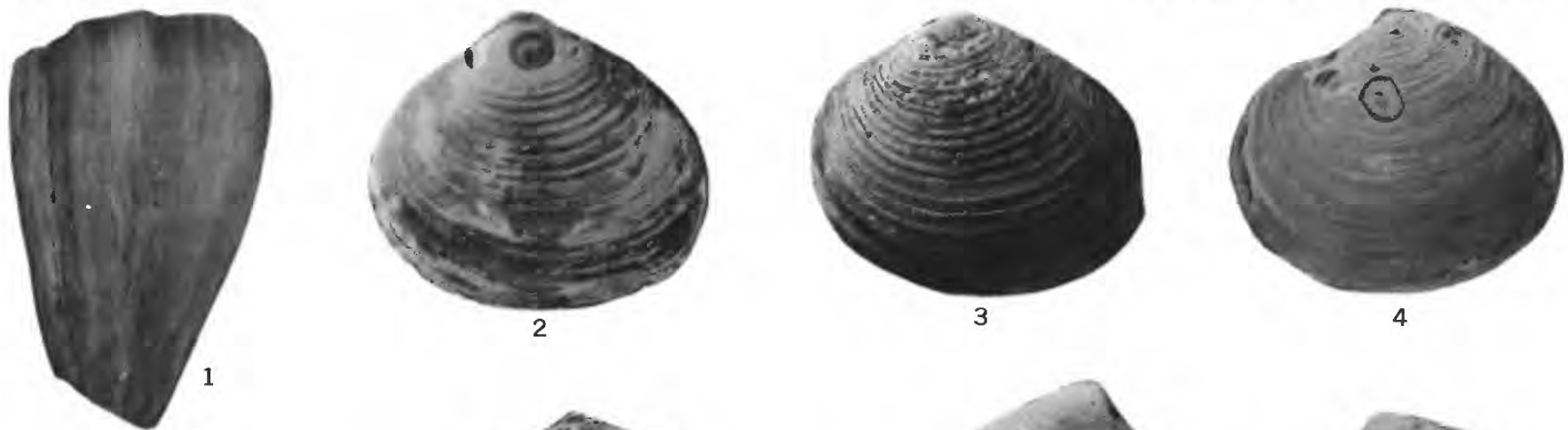

4
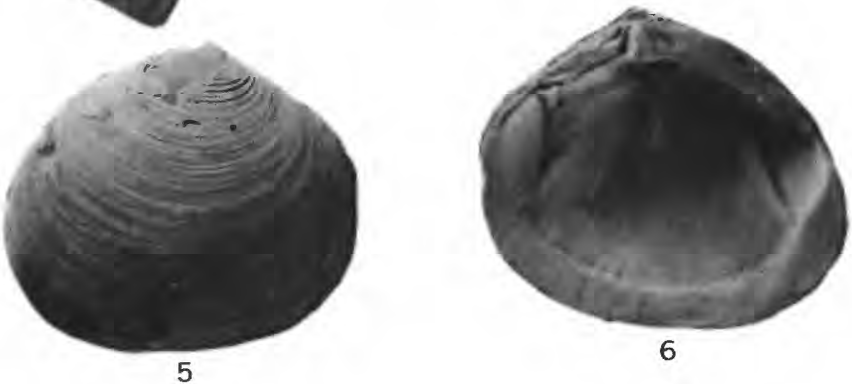

6
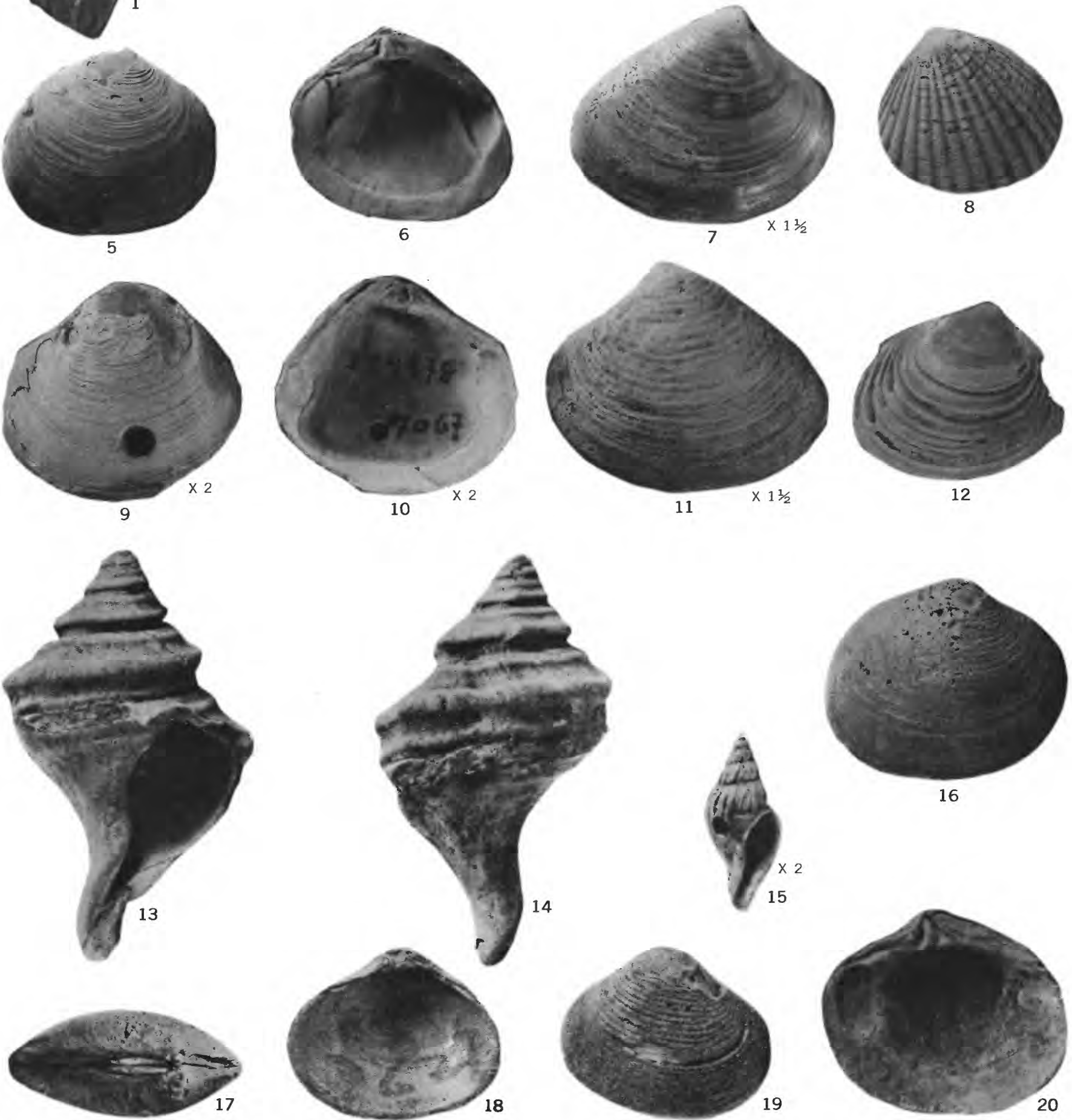

FOSSILS OF THE GUBIK FORMATION, NEPTUNEA VENTRICOSA(?) SOLUTA FAUNULE, PEARD BAY, AND NEPTUNEA VENTRICUSA CLARKI FAUNULE, SKLLL CLIFF, PEARD BAY 


\section{PLATE 16}

[Figures natural size unless otherwise indicated]

Figure 1. Neptunea ventricosa soluta? (Heermann) (p. 112).

Figured fragment, USNM 561946; height, $49.6 \mathrm{~mm}$. Locality, USGS Tert. loc. 1/1087.

2, 3. Astarte cf. A. subequilatera Sowerby (p. 115).

2. Figured specimen, USNM 561947 ; length, $40.8 \mathrm{~mm}$; height, $35 \mathrm{~mm}$.

3. Figured specimen, USNM 561948; length, $41.4 \mathrm{~mm}$; height, $34.3 \mathrm{~mm}$. Locality, USGS Tert. loc. 1/1087.

4. Astarte aff. A. fabula Reeve (p. 115).

Figured specimen, USNM 561949; length, 387. mm; height, $32.5 \mathrm{~mm}$. Locality, USGS Tert. loc. 1/1087.

5, 6. Astarte broweri Meek (p. 115-116).

Figured specimen, USNM 324376; length, $39.3 \mathrm{~mm}$; height, $32.8 \mathrm{~mm}$. Locality. USGS Tert. loc. 7067.

7, 11. Astarte leffingwelli Dall (p. 116).

7. Figured specimen, USNM 561950, $\times 1 \frac{1}{1} 2$; length, $30.6 \mathrm{~mm}$; height, $25.3 \mathrm{~mm}$.

11. Figured specimen, USNM 561951, $\times 1 \frac{1}{2}$, a partly decorticated specimen; length, $32.9 \mathrm{~mm}$; height, $26.2 \mathrm{~mm}$. Locality, USGS Tert. loc. 1/1087.

8. Cardita (Cyclocardia) cf. crebricostata (Krause) (p. 117).

Figured specimen, USNM 561952; length, $31.4 \mathrm{~mm}$; height, $27.6 \mathrm{~mm}$. Locality, USGS Tert. loc. 7228.

9, 10. Astarte bennetti Dall (p. 116).

Figured specimen, USNM 324378, × 2; length, $20.4 \mathrm{~mm}$; height, $18.6 \mathrm{~mm}$. Locality, USGS Tert. loc. 7067.

12. Serripes groenlandicus (Bruguière) (p. 117).

Figured specimen, USNM 561953; length, $35.8 \mathrm{~mm}$. Locality, USGS Tert. loc. 1/1087.

13, 14. Neptunea ventricosa clarki (Meek) (p. 111).

Holotype after Meek, U. Calif. 30593; height, $76 \mathrm{~mm}$. Locality, Univ. of Calif. 3627.

15. Lora skullcliffensis Meek (p. 114).

Holotype after Meek, U. Calif. 30594, $\times 2$; height, $16 \mathrm{~mm}$; diameter, $7 \mathrm{~mm}$. Locality, Univ. of Calif. 3627.

16, 17, 20. Astarte broweri Meek (p. 115-116).

16, 20. Holotype after Meek, U. Calif. 30595 ; length, $44 \mathrm{~mm}$; height, $36 \mathrm{~mm}$.

17. Dorsal view of both valves. Locality, Univ. of Calif. 3627.

18, 19. Astarte ?fabula Reeve (p. 115).

Figures specimen after Meek. Locality, Univ. of Calif. 3627. 


\section{PLATE 17}

[Figures natural size unless otherwise indicated]

Figures 1, 2. Buccinum angulosum Gray (p. 113-114).

Figured specimen, USNM 561954, × 11/2; height, $33.7 \mathrm{~mm}$; diameter, $21 \mathrm{~mm} . \quad$ Locality, USGS Tert. loc. 15937.

3. Serripes groenlandicus (Burguière) (p. 117).

Figured specimen, USNM 561955; length, $32.6 \mathrm{~mm}$. Locality, USGS Tert. loc. 15937.

4. Balanus rostratus alaskensis Pilsbry (p. 120).

Figured specimen, USNM 324382, $\times 2$; height, $25 \mathrm{~mm}$; figure is upside down. Locality, USGS Tert. loc. 7228 (Peard Bay).

5. Macoma calcarea (Gmelin) (p. 117).

Figured specimen, USNM 561956, × 2; length, 16 mm. Locality, USGS Tert. loc. 15937.

6. Mya ef. M. arenaria Linné (p. 118).

Figured specimen, USNM 561957; length, 45 mm. Locality, USGS Tert. loc. 15937.

7. Astarte ?vernicosa Dall (p. 116).

Figured specimen, USNM 561958, $\times$ 11/2, a fragment of a right valve; height, $26.5 \mathrm{~mm}$. Locality, USGS Tert. loc. 15937.

8. Saxicava pholadis (Linné) (p. 119).

Figured specimen, USN M 561959, × 2; length, $23.4 \mathrm{~mm}$; height, $6.8 \mathrm{~mm}$. Locality, USGS Tert. loc. 15937.

9. Neptunea andersoni (Martin).

Holotype, U. Calif. 12336, $\times 3 / 4$; height, $85 \mathrm{~mm}$. Locality, Wildcat series of Lawson (1894) (Pliocene), California, Univ. Calif. 1878.

10. Neptunea aff. N. lyrata (Gmelin) (p. 113).

Figured specimen, USNM 561960; height, $70 \mathrm{~mm}$. Locality, Pliocene (?), Middleton Island, Gulf of Alaska, 17742 .

11. Neptunea lyrata (Gmelin) (p. 113).

Figured specimen, USNM 561961; height, $82 \mathrm{~mm}$; diameter, $43 \mathrm{~mm}$. Locality, sea cliff west of Icy Cape (moraine of Guyot Glacier), Gulf of Alaska, 17820. Pleistocene or Recent.

12. Neptunea aff. N. lyrata (Gmelin) and N. ventricosa soluta (Heermann) (p. 112).

Figured specimen, USNM 561962; height, $58 \mathrm{~mm}$. Locality, Saint Paul, Pribilof Islands (late Pliocene or early Pleistocene), 8278.

13. Neptunea lyrata ef. pribiloffensis (Dall) (p. 112).

Figured specimen, USNM 561963; height, $64 \mathrm{~mm}$. Locality, Kachemak Bay, Cook Inlet, 30 feet above high tide (Pleistocene), 5871.

14. Neptunea ventricosa (Gmelin) (p. 112).

Figured specimen, USNM 561964; height, $76 \mathrm{~mm}$; a slender variety having two weak spirals exposed above the suture. Locality, Saint Lawrence Island, Bering Sea (Recent). H. B. Allen, collector

15. Neptunea ventricosa soluta (Heermann) (p. 112).

Figured specimen, USNM 561965, $\times \frac{2}{3}$; height, $71 \mathrm{~mm}$; characterized by a single strong spiral that breaks up into spirally elongate nodes. Locality, Saint Lawrence Island, Bering Sea (Recent). H. B. Allen, collector

16, 17. Neptunea ventricosa mesleri (Dall) (p. 112).

16. A figured specimen after MacNeil, USNM 499028, height, $37.5 \mathrm{~mm}$. Locality, USGS Tert. loc. 14866.

17. A basal fragment after Dall, USNM 324412; characterized by a single strong spiral that breaks up into axially elongate nodes; the adult has strong axial ribs on the body whorl. Locality, USGS Tert. loc. 5074. Both from Intermediate Beach, Nome, Alaska. 


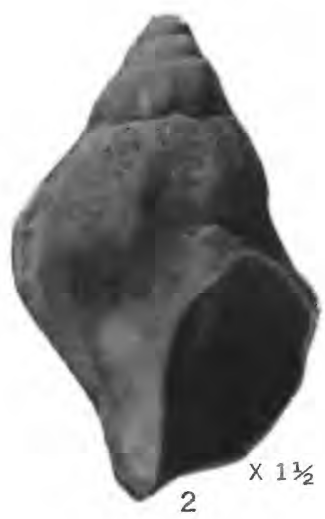

I'ROFESSIONAL PAPER 294 PLATE 17
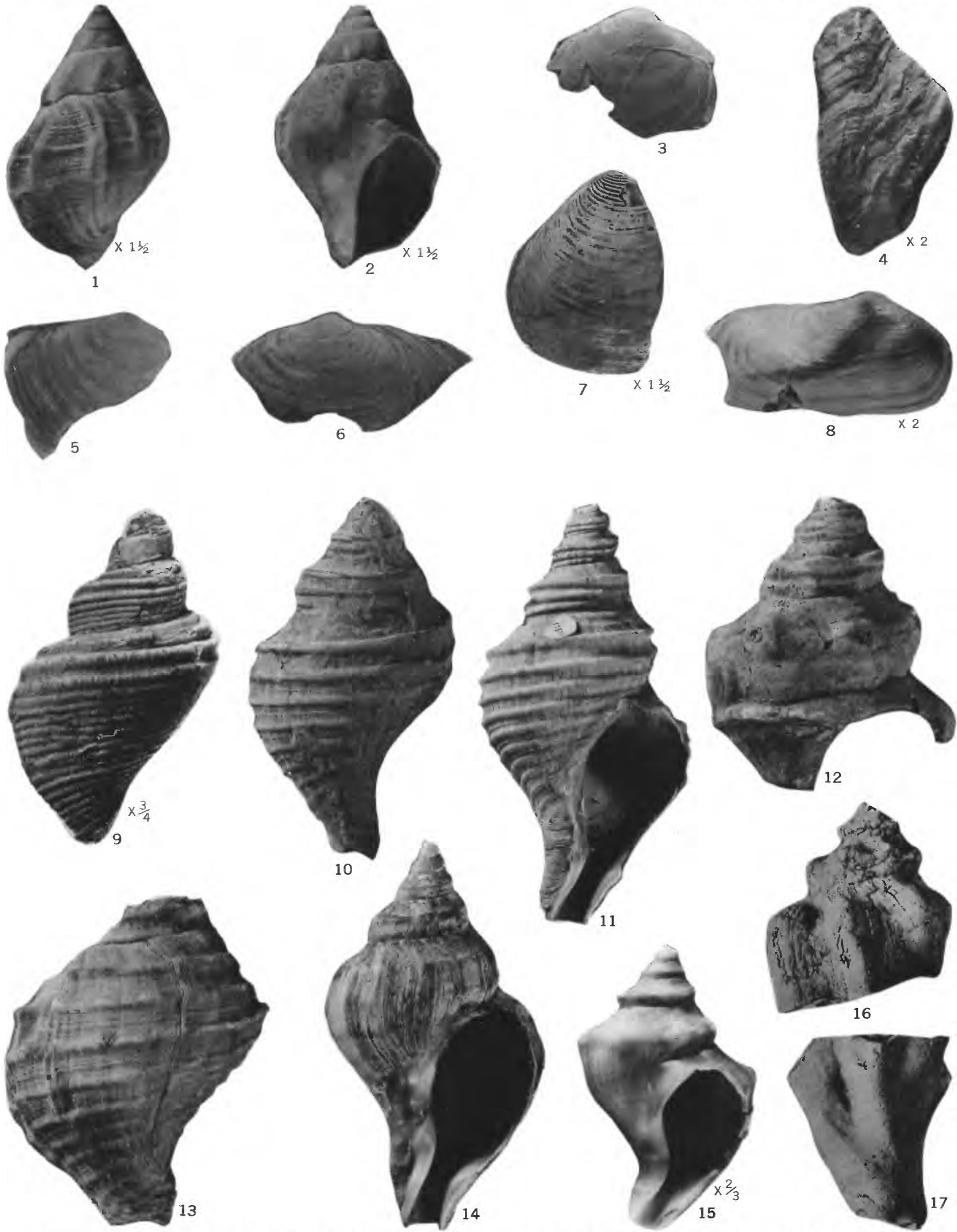

FOSSILS OF THE GUBIK FORMATION, POINT BARROW TERRACE GRAVEL DEPOSITS, AND WESTERN AMERICA NEPTUNEA OF THE N. LIRATA-N. VENTRICOSA GROUP 